Nevada

Environmental

Restoration

Project

Streamlined Approach for

Environmental Restoration (SAFER)

Plan for Corrective Action Unit 130:

Storage Tanks

Nevada Test Site, Nevada

Controlled Copy No.:

Revision No.: 0

June 2008

Approved for public release; further dissemination unlimited.

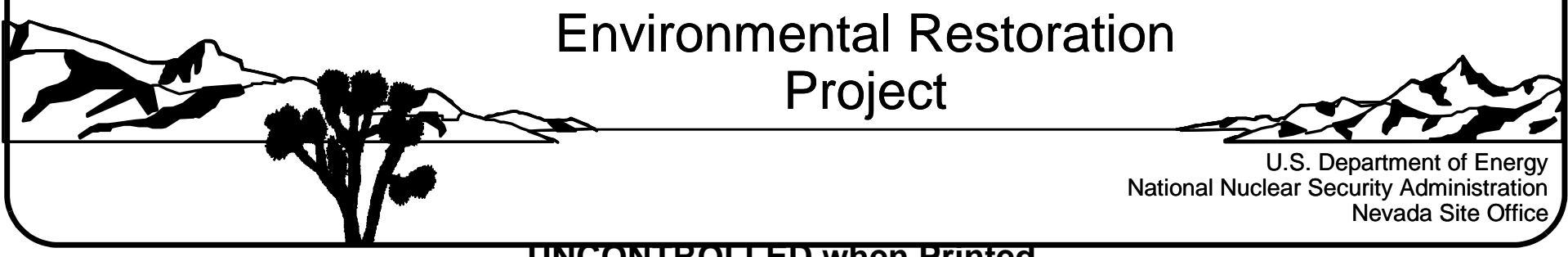


Available for public sale, in paper, from:

U.S. Department of Commerce

National Technical Information Service

5285 Port Royal Road

Springfield, VA 22161

Phone: 800.553 .6847

Fax: 703.605.6900

Email: orders@ntis.gov

Online ordering: http://www.ntis.gov/ordering.htm

Available electronically at http://www.osti.gov/bridge

Available for a processing fee to U.S. Department of Energy and its contractors, in paper, from:

\section{U.S. Department of Energy}

Office of Scientific and Technical Information

P.O. Box 62

Oak Ridge, TN 37831-0062

Phone: 865.576.8401

Fax: 865.576.5728

Email: reports@adonis.osti.gov

Reference herein to any specific commercial product, process, or service by trade name, trademark, manufacturer, or otherwise, does not necessarily constitute or imply its endorsement, recommendation, or favoring by the United States Government or any agency thereof or its contractors or subcontractors. 


\title{
STREAMLINED APPROACH FOR ENVIRONMENTAL RESTORATION (SAFER) PLAN FOR CORRECTIVE ACTION UNIT 130: STORAGE TANKS NEVADA TEST SITE, NEVADA
}

\author{
U.S. Department of Energy \\ National Nuclear Security Administration \\ Nevada Site Office \\ Las Vegas, Nevada
}

Controlled Copy No.:

Revision No.: 0

June 2008

Approved for public release; further dissemination unlimited.

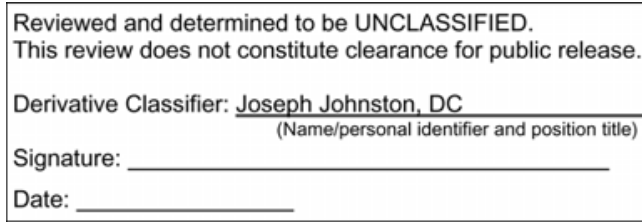


STREAMLINED APPROACH FOR ENVIRONMENTAL RESTORATION (SAFER) PLAN FOR CORRECTIVE ACTION UNIT 130: STORAGE TANKS NEVADA TEST SITE, NEVADA

Approved by: /s/ Tiffany Lantow for

Date: $\underline{06 / 16 / 008}$

Kevin J. Cabble

Federal Sub-Project Director

Industrial Sites Sub-Project

Approved by: /s/ Kevin Cabble for

Date: 06/16/008

Robert F. Boehlecke

Federal Project Director

Environmental Restoration Project 


\section{Table of Contents}

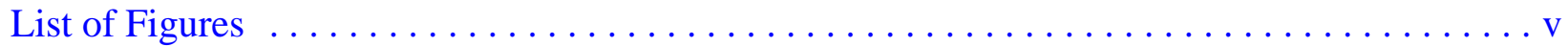

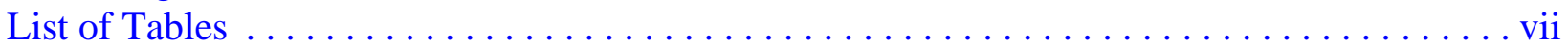

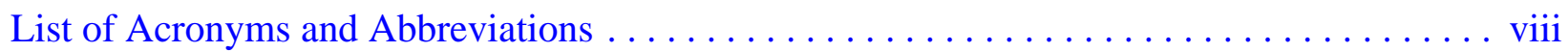

Executive Summary . . . . . . . . . . . . . . . . . . . . . . . . . ES-1

$1.0 \quad$ Introduction. . . . . . . . . . . . . . . . . . . . . . . . . . . 1

1.1 SAFER Process Description . . . . . . . . . . . . . . . . . . 3

1.2 Summary of Corrective Actions and Closures .................. 4

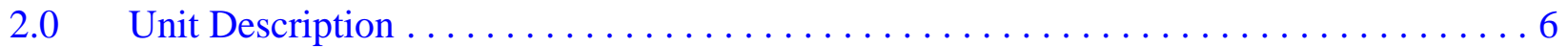

2.1 Corrective Action Site 01-02-01, Underground Storage Tank . . . . . . . . . 6

2.1.1 History and Process Knowledge.................... 6

2.1.2 Available Characterization Information . . . . . . . . . . . . . . 8

2.2 Corrective Action Site 07-02-01, Underground Storage Tanks . . . . . . . . . 8

2.2.1 History and Process Knowledge................... 8

2.2.2 Available Characterization Information . . . . . . . . . . . . . . 11

2.3 Corrective Action Site 10-02-01, Underground Storage Tank . . . . . . . . . . 11

2.3.1 Historical and Process Knowledge . . . . . . . . . . . . . . . 11

2.3.2 Available Characterization Information . . . . . . . . . . . . . . . . . 14

2.4 Corrective Action Site 20-02-03, Underground Storage Tank . . . . . . . . . . . 14

2.4.1 Historical and Process Knowledge . . . . . . . . . . . . . . . . . . . 14

2.4.2 Available Characterization Information . . . . . . . . . . . . . . . . . . 14

2.5 Corrective Action Site 20-99-05, Tar Residue . . . . . . . . . . . . . . . . 17

2.5.1 Historical and Process Knowledge. . . . . . . . . . . . . . . 17

2.5.2 Available Characterization Information . . . . . . . . . . . . . . . . 17

2.6 Corrective Action Site 22-02-02, Buried UST Piping . . . . . . . . . . . . 20

2.6.1 Historical and Process Knowledge . . . . . . . . . . . . . . 20

2.6 .2 Available Characterization Information . . . . . . . . . . . . . . . 20

2.7 Corrective Action Site 23-02-07, Underground Storage Tank . . . . . . . . . . . 20

2.7.1 Historical and Process Knowledge. . . . . . . . . . . . . . 23

2.7.2 Available Characterization Information . . . . . . . . . . . . . . 23

$3.0 \quad$ Data Quality Objectives . . . . . . . . . . . . . . . . . . . . . . 25

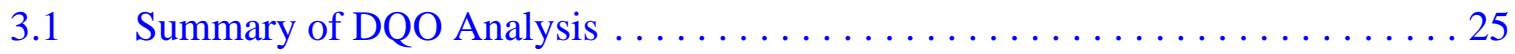

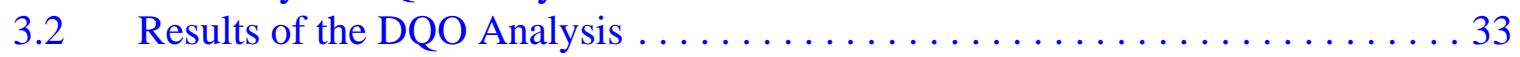

3.2.1 Action Level Determination and Basis.................. 33

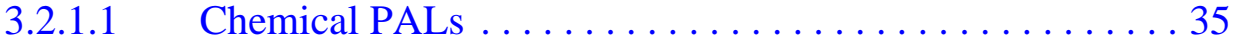

3.2.1.2 Total Petroleum Hydrocarbon PALs . . . . . . . . . . 35

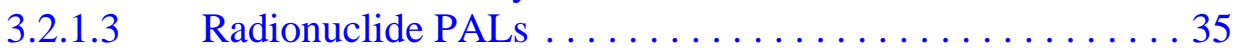

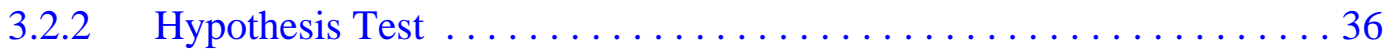

3.2.3 Statistical Model ............................ 36 


\section{Table of Contents (Continued)}

3.2.4 Design Description/Option......................... 36

3.2.5 Conceptual Site Model and Drawing .................... 37

$4.0 \quad$ Field Activities and Closure Objectives $\ldots \ldots \ldots \ldots \ldots \ldots \ldots \ldots \ldots \ldots \ldots$

$4.1 \quad$ Contaminants of Potential Concern $\ldots \ldots \ldots \ldots \ldots \ldots \ldots \ldots \ldots \ldots \ldots \ldots$

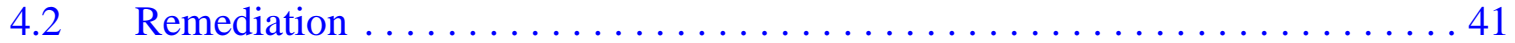

$4.3 \quad$ Verification...................................... 41

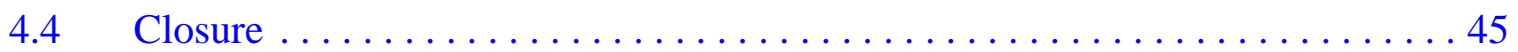

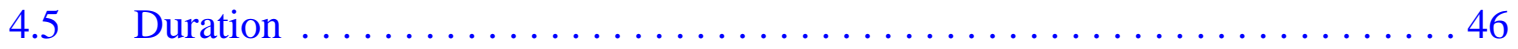

$5.0 \quad$ Reports and Records Availability ........................... 47

$6.0 \quad$ Investigation/Remediation Waste Management ................... 48

$6.1 \quad$ Waste Minimization ................................ 48

$6.2 \quad$ Potential Waste Streams . . . . . . . . . . . . . . . . . . . . . . . . . 49

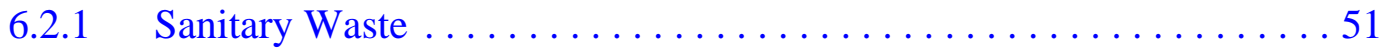

6.2.2 Low-Level Radioactive Waste ...................... 51

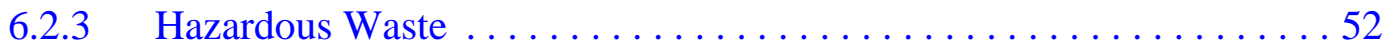

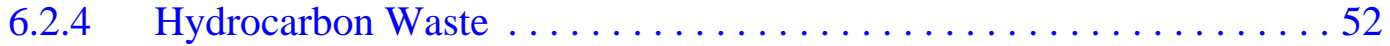

6.2 .5 Mixed Low-Level Waste $\ldots \ldots \ldots \ldots \ldots \ldots \ldots \ldots \ldots \ldots \ldots \ldots$

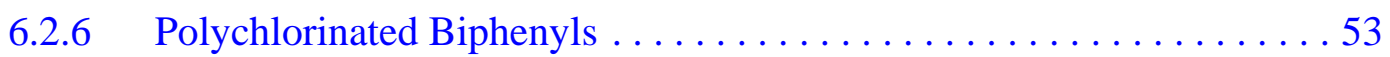

6.3 Management of Specific Waste Streams ...................... 53

6.3.1 Personal Protective Equipment...................... 53

6.3.2 Management of Decontamination Rinsate .................. 54

6.3.3 Management of Soil .......................... 54

6.3.4 Management of Debris ............................ 55

6.3.5 Field-Screening Waste ........................... 55

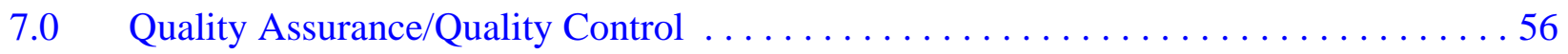

$7.1 \quad$ Sample Collection Activities . ......................... 56

7.2 Applicable Laboratory/Analytical Data Quality Indicators ............. 57

$7.2 .1 \quad$ Precision ................................. 58

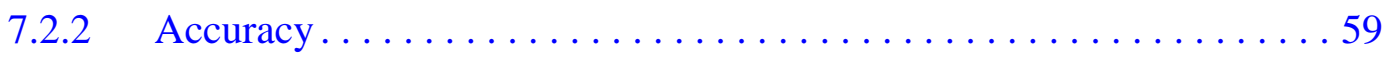

7.2 .3 Representativeness ..........................6 60

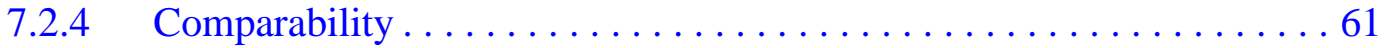

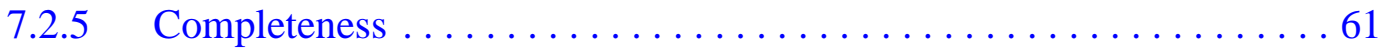

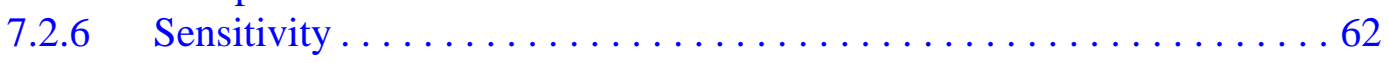

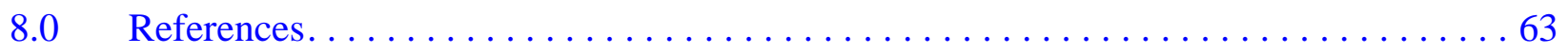




\section{Table of Contents (Continued)}

\section{Appendix A - Project Organization}

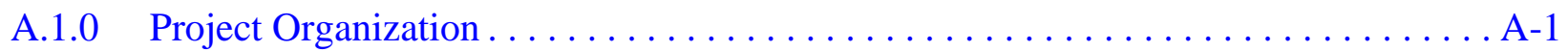

\section{Appendix B - Data Quality Objective Process}

B.1.0 Introduction. . . . . . . . . . . . . . . . . . . . . . . . . . . . . .

B.2.0 Step 1 - State the Problem. . . . . . . . . . . . . . . .

B.2.1 Planning Team Members $\ldots \ldots \ldots \ldots \ldots \ldots \ldots \ldots \ldots \ldots \ldots \ldots \ldots \ldots \ldots$

B.2.2 Conceptual Site Model .............................. B-3

B.2.2.1 Contaminant Release ........................... B-4

B.2.2.2 Potential Contaminants......................... B-9

B.2.2.3 Contaminant Characteristics...................... B-9

B.2.2.4 Site Characteristics ......................... B-11

B.2.2.5 Migration Pathways and Transport Mechanisms ........... B-12

B.2.2.6 Exposure Scenarios........................ B-12

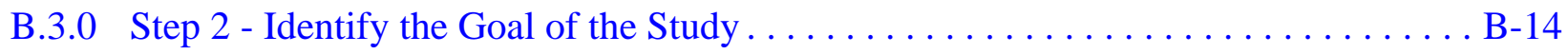

B.3.1 Decision Statements . . . . . . . . . . . . . . . . . . . . . B -14

B.3.2 Alternative Actions to the Decisions $\ldots \ldots \ldots \ldots \ldots \ldots \ldots \ldots \ldots \ldots \ldots \ldots \ldots$

B.3.2.1 Alternative Actions to Decision I . . . . . . . . . . . . . B-16

B.3.2.2 Alternative Actions to Decision II . . . . . . . . . . . . B-17

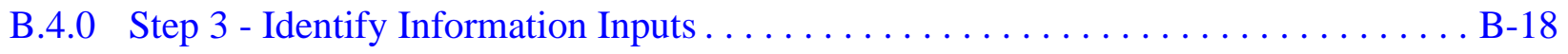

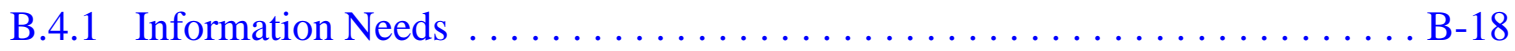

B.4.2 Sources of Information .......................

B.4.2.1 Sample Locations ......................... B-19

B.4.2.1.1 Judgmental Approach for Sampling

Location Selection ..................... B-19

B.4.2.2 Analytical Methods......................... B-21

B.5.0 Step 4 - Define the Boundaries of the Study $\ldots \ldots \ldots \ldots \ldots \ldots \ldots \ldots \ldots \ldots \ldots \ldots \ldots \ldots$

B.5.1 Target Populations of Interest. . . . . . . . . . . . . . . . . . .

B.5.2 Spatial Boundaries .................................... B-22

B.5.3 Practical Constraints . . . . . . . . . . . . . . . . . . . . . . .

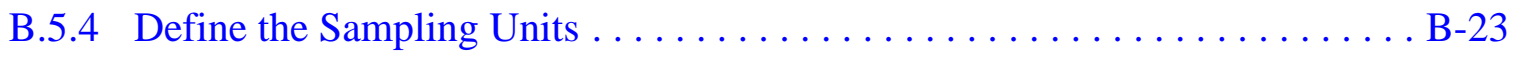

B.6.0 Step 5 - Develop the Analytic Approach . . . . . . . . . . . . . . . . . . . . . . B-25

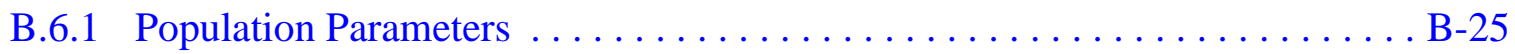

B.6.2 Action Levels . . . . . . . . . . . . . . . . . . . . . . . . . . B-25 


\section{Table of Contents (Continued)}

B.6.2.1 Chemical PALs........................... B-26

B.6.2.2 Total Petroleum Hydrocarbon PALs $\ldots \ldots \ldots \ldots \ldots \ldots \ldots \ldots . . \ldots \ldots$

B.6.2.3 Radionuclide PALs..........................

B.6.3 Decision Rules . . . . . . . . . . . . . . . . . . . . . . . . . . . . . B-27

B.7.0 Step 6 - Specify Performance or Acceptance Criteria . . . . . . . . . . . . . . . B-29

B.7.1 Decision Hypotheses. . . . . . . . . . . . . . . . . . . . . . . . . . B-29

B.7.2 False Negative Decision Error $\ldots \ldots \ldots \ldots \ldots \ldots \ldots \ldots \ldots \ldots \ldots \ldots \ldots \ldots \ldots \ldots \ldots$

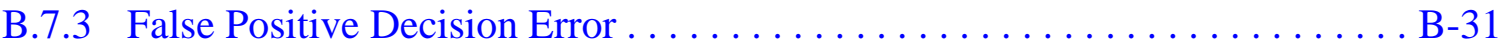

B.8.0 Step 7 - Develop the Plan for Obtaining Data $\ldots \ldots \ldots \ldots \ldots \ldots \ldots \ldots \ldots$ B-33

B.8.1 Decision I Sampling . . . . . . . . . . . . . . . . . $\ldots \ldots \ldots \ldots \ldots$

B.8.2 Decision II Sampling $\ldots \ldots \ldots \ldots \ldots \ldots \ldots \ldots \ldots \ldots \ldots \ldots \ldots \ldots \ldots \ldots \ldots \ldots \ldots \ldots$

B.8.3 Corrective Action Site 01-02-01, Underground Storage Tank............ . B-34

B.8.4 Corrective Action Site 07-02-01, Underground Storage Tanks . . . . . . . . . . B-36

B.8.5 Corrective Action Site 10-02-01, Underground Storage Tank. . . . . . . . . B-38

B.8.6 Corrective Action Site 20-02-03, Underground Storage Tank. . . . . . . . . B-40

B.8.7 Corrective Action Site 20-99-05, Tar Residue .................. B-42

B.8.8 Corrective Action Site 22-02-02, Buried UST Piping . . . . . . . . . . . . B-42

B.8.9 Corrective Action Site 23-02-07, Underground Storage Tank. . . . . . . . . B-44

B.9.0 References................................... 


\section{List of Figures}

Number

Title

Page

1-1 Nevada Test Site Map with CAU 130 CAS Locations. . . . . . . . . . . . 2

1-2 Corrective Action Unit 130 Closure Decision Process. . . . . . . . . . . . . .5

2-1 CAS 01-02-01, Underground Storage Tank, Location with Respect to Area Buildings, Surrounding Roads, and Other Physical Features . . . . . . . . .7

2-2 CAS 01-02-01, Underground Storage Tank, Geophysical Survey . . . . . . . . . .9

2-3 CAS 07-02-01, Underground Storage Tanks, Location with Respect to Surrounding Roads, Other Physical Features, and the Man-Made Radiation Zones . . . . . . . . . . . . . . . . . . . . . . 10

2-4 CAS 07-02-01, Underground Storage Tanks, Geophysical Survey . . . . . . . . . 12

2-5 CAS 10-02-01, Underground Storage Tank, Location with Respect to Surrounding Roads and Other Physical Features . . . . . . . . . . . 13

2-6 CAS 10-02-01, Underground Storage Tank, Geophysical Survey . . . . . . . . . . 15

2-7 CAS 20-02-03, Underground Storage Tank, Location with Respect to Surrounding Roads and Other Physical Features . . . . . . . . . . . . . 16

2-8 CAS 20-02-03, Underground Storage Tank, Geophysical Survey . . . . . . . . . 18

2-9 CAS 20-99-05, Tar Residue, Location with Respect to Surrounding Roads and Other Physical Features . . . . . . . . . . . . . . . . . . 19

2-10 CAS 22-02-02, Buried UST Piping, Location with Respect to Surrounding Roads and Other Physical Features . . . . . . . . . . . 21

2-11 CAS 22-02-02, Buried UST Piping, Geophysical Survey . . . . . . . . . . .22

2-12 CAS 23-02-07, Underground Storage Tank, Location with Respect to Surrounding Roads and Other Physical Features . . . . . . . . . . . . 24

3-1 Risk-Based Corrective Action Decision Process . . . . . . . . . . . . . . 34

3-2 Conceptual Site Model Diagram for CAU $130 \ldots \ldots \ldots \ldots \ldots \ldots$ 


\section{List of Figures (Continued)}

Number

Title

Page

3-3 Corrective Action Unit 130 Conceptual Site Model. . . . . . . . . . . . . . . . . 39

B.2-1 Conceptual Site Model for CAU 130 CASs.....................

B.2-2 Conceptual Site Model Diagram for CAU 130, Storage Tanks ............. B-8

B.3-1 SAFER Closure Decision Process for CAU $130 \ldots \ldots \ldots \ldots \ldots \ldots$.

B.8-1 Proposed Sample Strategy at CAS 01-02-01 ...................

B.8-2 Proposed Sample Strategy at CAS $07-02-01 \ldots \ldots \ldots \ldots \ldots \ldots \ldots$. $\ldots$-37

B.8-3 Proposed Sample Strategy at CAS $10-02-01 \ldots \ldots \ldots \ldots \ldots \ldots$. . . . . . . . .

B.8-4 Proposed Sample Strategy at CAS $20-02-03 \ldots \ldots \ldots \ldots \ldots \ldots \ldots$. . .

B.8-5 Proposed Sample Strategy at CAS $20-99-05 \ldots \ldots \ldots \ldots \ldots \ldots \ldots$ B-43

B.8-6 Proposed Sample Strategy at CAS 22-02-02 ................... B-45

B.8-7 Proposed Sample Strategy at CAS 23-02-07 ................... 


\section{List of Tables}

Number

Title

Page

3-1 Analytical Program (Includes Waste Characterization Analyses) . . . . . . . . 27

3-2 Constituents Reported by Analytical Methods . . . . . . . . . . . . . . . 28

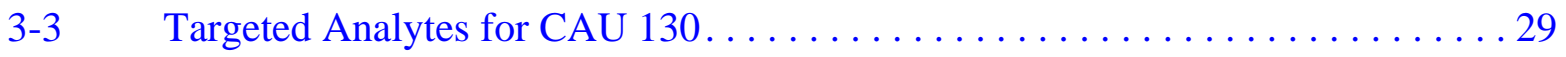

3-4 Analytical Requirements for Radionuclides for CAU $130 \ldots \ldots \ldots \ldots \ldots$

3-5 Analytical Requirements for Chemical COPCs for CAU $130 \ldots \ldots \ldots \ldots$

4-1 Sampling Approach for CAU 130 Corrective Action Sites . . . . . . . . . . . 43

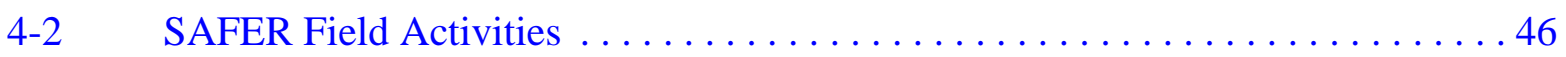

6-1 Waste Management Regulations and Requirements $\ldots \ldots \ldots \ldots \ldots$

7-1 Laboratory and Analytical Performance Criteria for CAU 130

Data Quality Indicators. . . . . . . . . . . . . . . . . . 57

B.2-1 Conceptual Site Model Description of Elements for Each CAS in CAU 130 . . . B-6

B.2-2 Analytical Program (Includes Waste Characterization Analyses) . . . . . . . . B-10

B.2-3 Targeted Contaminants for CAU $130 \ldots \ldots \ldots \ldots \ldots \ldots \ldots \ldots \ldots \ldots \ldots \ldots$

B.2-4 Land Use and Exposure Scenarios $\ldots \ldots \ldots \ldots \ldots \ldots \ldots \ldots \ldots \ldots \ldots$

B.5-1 Spatial Boundaries of CAU 130 CASs. . . . . . . . . . . . . . . . . B-23

B.5-2 Practical Constraints for the CAU 130 Field Investigation . . . . . . . . . . . . B-24 


\section{List of Acronyms and Abbreviations}

\begin{tabular}{|c|c|}
\hline ASTM & American Society for Testing and Materials \\
\hline bgs & Below ground surface \\
\hline CAI & Corrective Action Investigation \\
\hline CAS & Corrective Action Site \\
\hline CAU & Corrective Action Unit \\
\hline CFR & Code of Federal Regulations \\
\hline $\mathrm{COC}$ & Contaminant of concern \\
\hline COPC & Contaminant of potential concern \\
\hline CR & Closure Report \\
\hline CSM & Conceptual site model \\
\hline CTE & Coal tar epoxy \\
\hline DOE & U.S. Department of Energy \\
\hline DOT & U.S. Department of Transportation \\
\hline DQI & Data quality indicator \\
\hline DQO & Data quality objective \\
\hline DRO & Diesel-range organics \\
\hline EPA & U.S. Environmental Protection Agency \\
\hline FAL & Final action level \\
\hline FFACO & Federal Facility Agreement and Consent Order \\
\hline FSR & Field-screening result \\
\hline $\mathrm{ft}$ & Foot \\
\hline $\mathrm{ft}^{2}$ & Square foot \\
\hline gal & Gallon \\
\hline GPR & Ground-penetrating radar \\
\hline GRO & Gasoline-range organics \\
\hline HASL & Health and Safety Laboratory \\
\hline
\end{tabular}




\section{List of Acronyms and Abbreviations (Continued)}

\begin{tabular}{|c|c|}
\hline HWAA & Hazardous waste accumulation area \\
\hline IDW & Investigation-derived waste \\
\hline in. & Inch \\
\hline in./yr & Inches per year \\
\hline LCS & Laboratory control sample \\
\hline MDC & Minimum detectable concentration \\
\hline $\mathrm{mg} / \mathrm{kg}$ & Milligrams per kilogram \\
\hline $\mathrm{mi}$ & Mile \\
\hline $\mathrm{mrem} / \mathrm{yr}$ & Millirem per year \\
\hline MS & Matrix spike \\
\hline $\mathrm{mS} / \mathrm{m}$ & Millisiemens per meter \\
\hline MSD & Matrix spike duplicate \\
\hline $\mathrm{mV}$ & Millivolt \\
\hline N/A & Not applicable \\
\hline NAC & Nevada Administrative Code \\
\hline NAD & North American Datum \\
\hline NCRP & National Council on Radiation Protection and Measurements \\
\hline ND & Not detected \\
\hline NDEP & Nevada Division of Environmental Protection \\
\hline NNSA/NSO & $\begin{array}{l}\text { U.S. Department of Energy, National Nuclear Security Administration } \\
\text { Nevada Site Office }\end{array}$ \\
\hline NRS & Nevada Revised Statutes \\
\hline NTS & Nevada Test Site \\
\hline NSTec & National Security Technologies, LLC \\
\hline NTSWAC & Nevada Test Site Waste Acceptance Criteria \\
\hline NV/YMP & Nevada Yucca Mountain Project \\
\hline PAL & Preliminary action level \\
\hline
\end{tabular}




\section{List of Acronyms and Abbreviations (Continued)}

\begin{tabular}{|c|c|}
\hline PCB & Polychlorinated biphenyl \\
\hline POC & Performance Objective for the Certification of Nonradioactive Hazardous Waste \\
\hline PPE & Personal protective equipment \\
\hline ppt & Parts per thousand \\
\hline PRG & Preliminary remediation goal \\
\hline PSM & Potential source material \\
\hline QA & Quality assurance \\
\hline QAPP & Quality Assurance Project Plan \\
\hline QC & Quality control \\
\hline RadCon & Radiological Control \\
\hline RBCA & Risk-based corrective action \\
\hline RBSL & Risk-based screening level \\
\hline RCA & Radiologically controlled area \\
\hline RCRA & Resource Conservation and Recovery Act \\
\hline REECo & Reynolds Electrical \& Engineering Co., Inc. \\
\hline RESRAD & Residual Radioactive \\
\hline RL & Reporting limit \\
\hline RMA & Radioactive material area \\
\hline RPD & Relative percent difference \\
\hline SAFER & Streamlined Approach for Environmental Restoration \\
\hline SNJV & Stoller-Navarro Joint Venture \\
\hline SSTL & Site-specific target level \\
\hline SVOC & Semivolatile organic compound \\
\hline TCLP & Toxicity characteristic leaching procedure \\
\hline $\mathrm{TPH}$ & Total petroleum hydrocarbons \\
\hline TSCA & Toxic Substances Control Act \\
\hline
\end{tabular}




\section{List of Acronyms and Abbreviations (Continued)}

UCL Upper confidence limit

UST Underground storage tank

UTM Universal Transverse Mercator

VOC Volatile organic compound

VSP Visual Sample Plan

$\%$ Percent recovery

$\mu \mathrm{R} / \mathrm{hr} \quad$ Microroentgens per hour 


\section{Executive Summary}

This Streamlined Approach for Environmental Restoration (SAFER) Plan addresses the actions needed to achieve closure for Corrective Action Unit (CAU) 130, Storage Tanks, identified in the Federal Facility Agreement and Consent Order (FFACO) (1996, as amended February 2008). Corrective Action Unit 130 consists of the seven following corrective action sites (CASs) located in Areas 1, 7, 10, 20, 22, and 23 of the Nevada Test Site:

- $\quad$ 01-02-01, Underground Storage Tank

- 07-02-01, Underground Storage Tanks

- 10-02-01, Underground Storage Tank

- 20-02-03, Underground Storage Tank

- 20-99-05, Tar Residue

- 22-02-02, Buried UST Piping

- 23-02-07, Underground Storage Tank

This plan provides the methodology for field activities needed to gather the necessary information for closing each CAS. There is sufficient information and process knowledge from historical documentation and investigations of similar sites regarding the expected nature and extent of potential contaminants to recommend closure of CAU 130 using the SAFER process. Additional information will be obtained by conducting a field investigation before selecting the appropriate corrective action for each CAS. The results of the field investigation will support a defensible recommendation that no further corrective action is necessary. This will be presented in a Closure Report that will be prepared and submitted to the Nevada Division of Environmental Protection (NDEP) for review and approval.

The sites will be investigated based on the data quality objectives (DQOs) finalized on April 3, 2008, by representatives of NDEP; U.S. Department of Energy (DOE), National Nuclear Security Administration Nevada Site Office; Stoller-Navarro Joint Venture; and National Security Technologies, LLC. The DQO process was used to identify and define the type, amount, and quality of data needed to determine and implement appropriate corrective actions for each CAS in CAU 130.

The DQO process developed for this CAU identified the following expected closure options: (1) investigation and confirmation that no contamination exists above the final action levels, leading 
to a no further action declaration; (2) characterization of the nature and extent of contamination, leading to closure in place with use restrictions; or (3) clean closure by remediation and verification.

The following text summarizes the SAFER activities that will support the closure of CAU 130:

- Perform site preparation activities (e.g., utilities clearances, geophysical surveys).

- Move or remove and dispose of debris at various CASs, as required.

- Collect environmental samples from designated target populations (e.g., stained soil) to confirm or disprove the presence of contaminants of concern (COCs) as necessary to supplement existing information.

- If no COCs are present at a CAS, establish no further action as the corrective action.

- If COCs exist, collect environmental samples from designated target populations (e.g., clean soil adjacent to contaminated soil) and submit for laboratory analyses to define the extent of COC contamination.

- If a COC is present at a CAS, either:

- Establish clean closure as the corrective action. The material to be remediated will be removed, disposed of as waste, and verification samples will be collected from remaining soil, or

- Establish closure in place as the corrective action and implement the appropriate use restrictions.

- Obtain consensus from NDEP that the preferred closure option is sufficient to protect human health and the environment.

- Close the underground storage tank(s) and their contents, if any, in accordance with Nevada Administrative Code regulations.

- Remove the lead brick(s) found at any CAS in accordance with the Resource Conservation and Recovery Act.

This SAFER Plan has been developed in accordance with the FFACO that was agreed to by the State of Nevada; DOE, Environmental Management; U.S. Department of Defense; and DOE, Legacy Management (FFACO, 1996; as amended February 2008). Under the FFACO, this SAFER Plan will be submitted to NDEP for approval. Fieldwork will be conducted following approval of the plan. 


\subsection{Introduction}

This Streamlined Approach for Environmental Restoration (SAFER) Plan addresses the actions necessary for the closure of Corrective Action Unit (CAU) 130: Storage Tanks, Nevada Test Site (NTS), Nevada. It has been developed in accordance with the Federal Facility Agreement and Consent Order (FFACO) that was agreed to by the State of Nevada; U.S. Department of Energy (DOE), Environmental Management; U.S. Department of Defense; and DOE, Legacy Management (FFACO, 1996; as amended February 2008).

A SAFER may be performed when the following criteria are met:

- Conceptual corrective actions are clearly identified (although some degree of investigation may be necessary to select a specific corrective action before completion of the Corrective Action Investigation [CAI])

- Uncertainty of the nature, extent, and corrective action must be limited to an acceptable level of risk

- The SAFER Plan includes decision points and criteria for making data quality objective (DQO) decisions

The purpose of the investigation will be to document and verify the adequacy of existing information; affirm the decision for either clean closure, closure in place, or no further action; and provide sufficient data to implement the corrective action. The actual corrective action selected will be based on characterization activities implemented under this SAFER Plan. This SAFER Plan identifies decision points developed in cooperation with the Nevada Division of Environmental Protection (NDEP), where the DOE, National Nuclear Security Administration Nevada Site Office (NNSA/NSO) will reach consensus with NDEP before beginning the next phase of work.

Corrective Action Unit 130 is located in Areas 1, 7, 10, 20, 22, and 23 of the NTS, which is approximately 65 miles (mi) northwest of Las Vegas, Nevada (Figure 1-1). Corrective Action Unit 130 is comprised of the seven following corrective action sites (CASs) also shown on Figure 1-1:

- 01-02-01, Underground Storage Tank

- 07-02-01, Underground Storage Tanks 


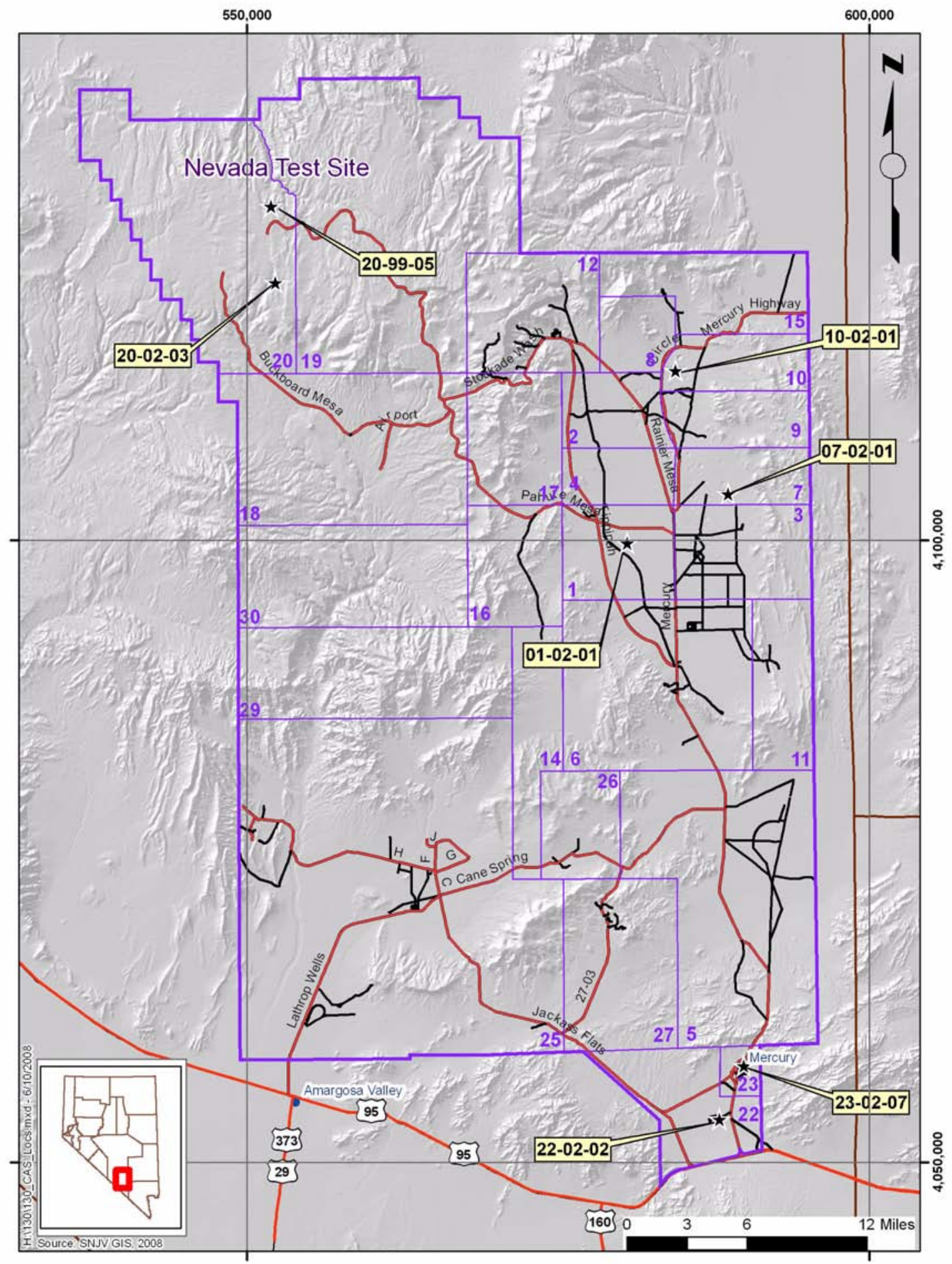

Figure 1-1

Nevada Test Site Map with CAU 130 CAS Locations 
- 10-02-01, Underground Storage Tank

- 20-02-03, Underground Storage Tank

- 20-99-05, Tar Residue

- 22-02-02, Buried UST Piping

- 23-02-07, Underground Storage Tank

There is sufficient information and process knowledge from historical documentation and investigations of similar sites (i.e., the expected nature and extent of contaminants of potential concern [COPCs]) to recommend closure of CAU 130 using the SAFER process (FFACO, 1996; as amended February 2008).

\subsection{SAFER Process Description}

Corrective action units that may be closed using the SAFER process have conceptual corrective actions that are clearly identified. Consequently corrective action alternatives can be chosen before completing a CAI, given anticipated investigation results.

The SAFER process combines elements of the DQO process and the observational approach to plan and conduct closure activities. The DQOs are used to identify the problem, and define the type and quality of data needed to complete closure of each CAS. The purpose of the investigation phase is to verify the adequacy of existing information used to determine the chosen corrective action and confirm that closure objectives were met.

Use of the SAFER process allows for technical decisions to be made based on incomplete but sufficient information, and the experience of the decision maker. Based on a detailed review of historical documentation, there is sufficient process knowledge to close CAU 130 using the SAFER process. Uncertainties are addressed by documented assumptions that are verified by sampling and analysis, data evaluation, and onsite observations, as necessary. Closure activities may proceed simultaneously with site characterization as sufficient data are gathered to confirm or disprove the assumptions made during selection of the corrective action. If, at any time during the closure process, new information is discovered that indicates that closure activities should be revised, closure activities will be re-evaluated as appropriate. 


\subsection{Summary of Corrective Actions and Closures}

The decision process for closure of CAU 130 is summarized in Figure 1-2. This process starts with the initial investigation in which the appropriate target population(s) within each CAS (defined in the DQO process, Appendix B) is sampled. If contaminants are detected at concentrations that are above the final action levels (FALs) and remediation is feasible, the nature and extent of contamination will be delineated by additional sampling. However, contingencies are built into the process in the event new information is identified that indicates the selected closure option should be revised. The process ends with closure of the site based on laboratory analytical results of the environmental samples and the preparation of a Closure Report (CR). Corrective action alternatives of closure in place and clean closure will be evaluated for each CAS with contaminants above FALs.

Decision points that require a consensus be reached between the NNSA/NSO and NDEP before continuing are indicated in Figure 1-2.

In addition to the previously discussed hold/decision points, work may be temporarily suspended until the issue can be satisfactorily resolved if any of the following unexpected conditions occur:

- Conditions outside the scope of work are encountered.

- Radiological screening yields results that require an upgrade in procedures to continue survey work in specific areas.

- Elevated levels of additional contaminants of concern (COCs) are found that were not originally identified as being present at the sites.

- Unexpected conditions including unexpected waste and/or contamination are encountered.

- $\quad$ Out-of-scope work activities are required due to the detection of other COCs that would require re-evaluating a disposal pathway, such as with hazardous or low-level waste.

- Unsafe conditions or work practices. 


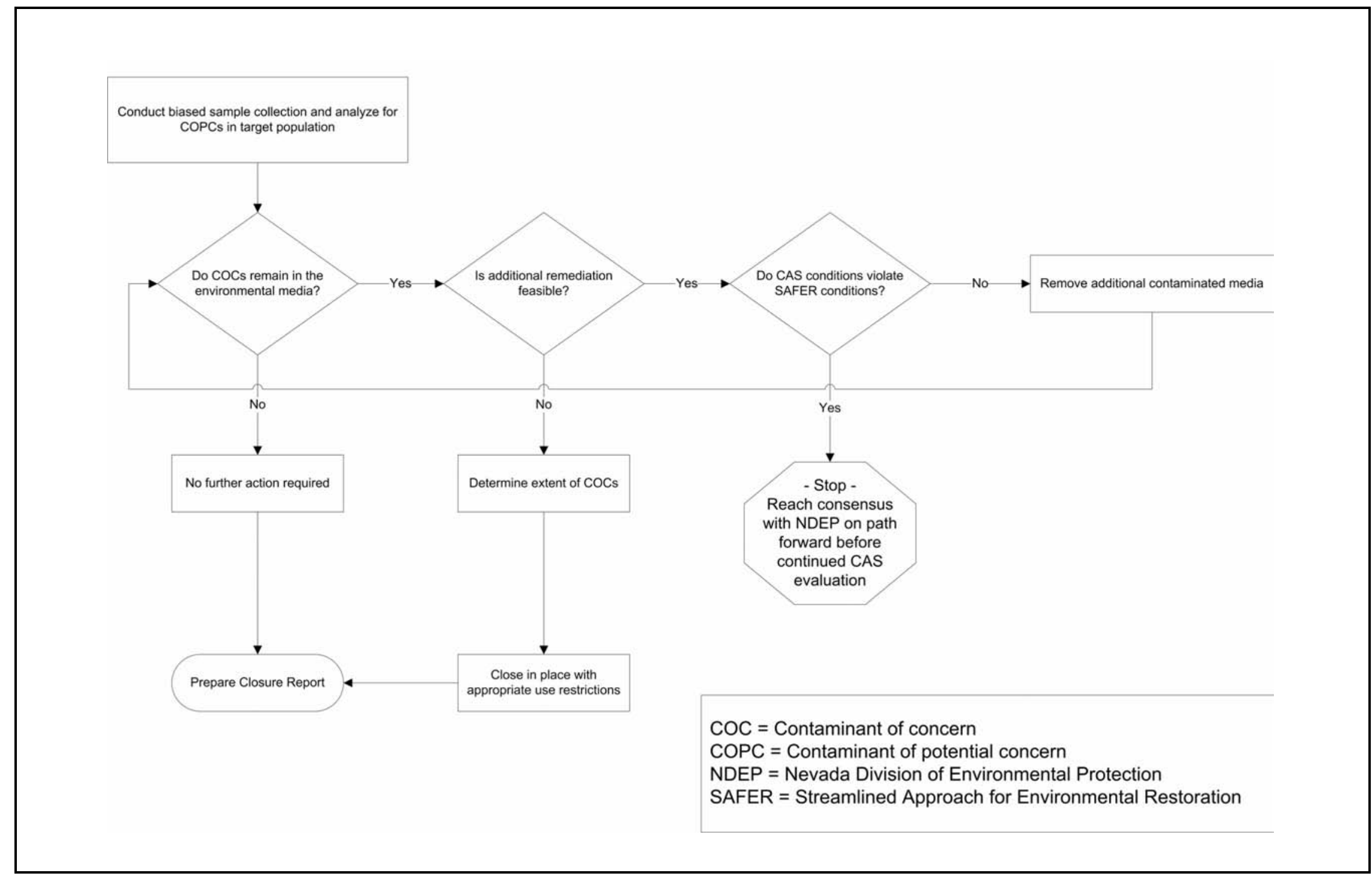

Figure 1-2

Corrective Action Unit 130 Closure Decision Process 


\subsection{Unit Description}

The CASs within CAU 130 are located within Areas 1, 7, 10, 20, 22, and 23 of the Nevada Test Site (NTS) (see Figure 1-1). The operational history, process knowledge, and existing information for each CAS are summarized in this section. Process knowledge for the CASs in CAU 130 has been obtained through historical document reviews, engineering drawing and map reviews, and interviews with past and present NTS employees. Some uncertainty remains regarding general knowledge of past operations for this CAU. Site-specific historical documentation pertaining to each CAS is also limited. Based on the process knowledge and information about the CASs, assumptions were made to formulate a conceptual site model (CSM) that describes the most probable scenario for the current conditions at each CAS. Section 3.2.5 provides additional information on the CSM developed for the CASs in CAU 130.

\subsection{Corrective Action Site 01-02-01, Underground Storage Tank}

Corrective Action Site 01-02-01 consists of a potential release associated with a underground storage tank (UST) located within the Apple II Historic District, between Buildings 1-31.1e1 and 1-31.4b1 in Area 1 of the NTS. A 6-inch (in.) covered metal pipe is visible at ground surface. The pipe cover is labeled “GAS.” Figure 2-1 shows CAS 01-02-01 location with respect to area buildings, surrounding roads, and other physical features.

\subsubsection{History and Process Knowledge}

The location of CAS 01-02-01 is within the Apple II test District near the center of the NTS on the western side of Yucca Flat. There were 17 projects conducted in relation to the Apple II tests. Of these 17 tests, two may be associated with CAS 01-02-01: Project 35.4a, named "Effects of a Nuclear Explosion on Industrial and Domestic Gas Storage and Distribution (Liquefied Petroleum Gas),” and Project 35.4b, named "Effects of a Nuclear Explosion on Industrial and Domestic Gas Storage and Distribution (Natural and Manufactured Gas).”

A natural and manufactured gas underground installation exists between Buildings 1-31.1e1 and 1-34.1b1. This installation includes " $\mathrm{H}$ " assemblies of 6-in. pipe, valves in valve pits, buried valves and street regulator valves, and service pipes connected to residential-type pressure regulators and 


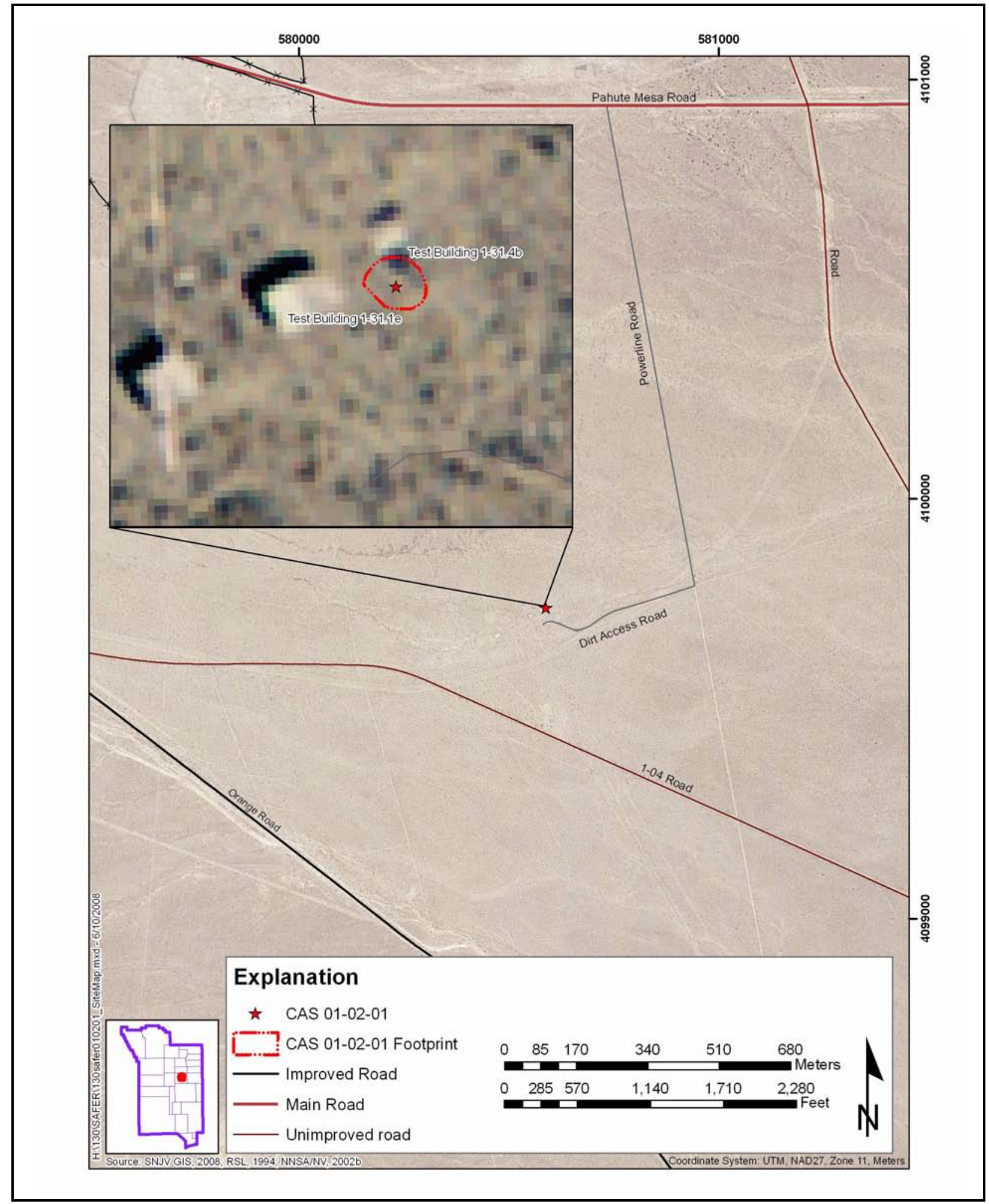

Figure 2-1

CAS 01-02-01, Underground Storage Tank, Location with Respect to Area Buildings, Surrounding Roads, and Other Physical Features 
meters that connected to gas appliances in the buildings (DRI, 2000). It is unknown whether there was a UST with natural, manufactured, or liquefied petroleum placed at CAS 01-02-01 as there is no indication on any historical photographs, engineering drawings, or maps.

\subsubsection{Available Characterization Information}

There are no analytical data for CAS 01-02-01. The geophysical survey in Figure 2-2 is the contoured normalized EM61 bottom coil response. Values higher than 20 millivolts indicate anomalous readings due to metallic material at or near the surface. The data indicate significant portions of the survey area have no surface or subsurface metal. Anomalies exist near the location of the two concrete and metal structures and around the steel "GAS" cap. The anomaly near the "GAS" cap is typical of a steel vertical stick-up pipe and not of a steel UST. No anomaly typical of a UST exists within the EM61 survey area. In addition, no linear anomalies typical of metallic pipelines and/or utilities are present in the survey area (Fahringer, 2004).

An aerial radiological survey was conducted of the NTS to include CAS 01-02-01. The survey measured the terrestrial gamma radiation at the levels of natural and man-made radiation. This survey at the location of CAS 01-02-01 shows a radiation level at or near background levels (BN, 1999).

\subsection{Corrective Action Site 07-02-01, Underground Storage Tanks}

Corrective Action Site 07-02-01 consists of a potential release associated with USTs located in Area 7, east of the T7c atmospheric test site. The CAS location is at an instrumentation shelter area which includes Station 7-235. Figure 2-3 shows CAS 07-02-01 with respect to surrounding roads, other physical features, and the man-made radiation zones.

\subsubsection{History and Process Knowledge}

Corrective Action Site 07-02-01 is located in Area 7 west of the T7c atmospheric test site. The site was identified by the original Reynolds Electrical Engineering Co., Inc. (REECo) document as possible buried USTs (REECo, 1991). The engineering drawings and site visit did not reveal any above ground features consistent with USTs (e.g., vent pipes). There is, however, a sign and opening to the Station 7-235 which was an instrument shelter during atmospheric testing. The as-built 

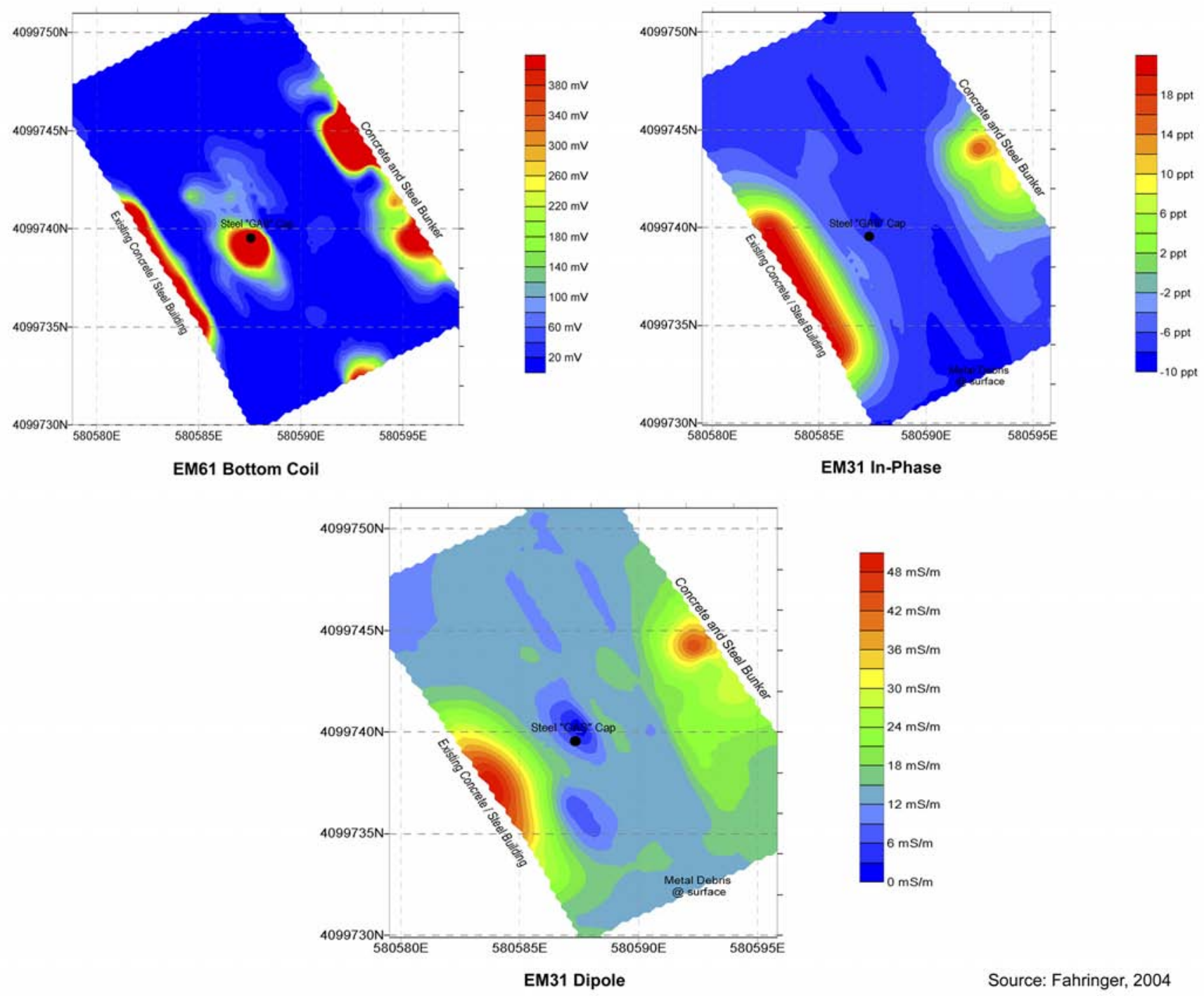

Figure 2-2

CAS 01-02-01, Underground Storage Tank, Geophysical Survey 


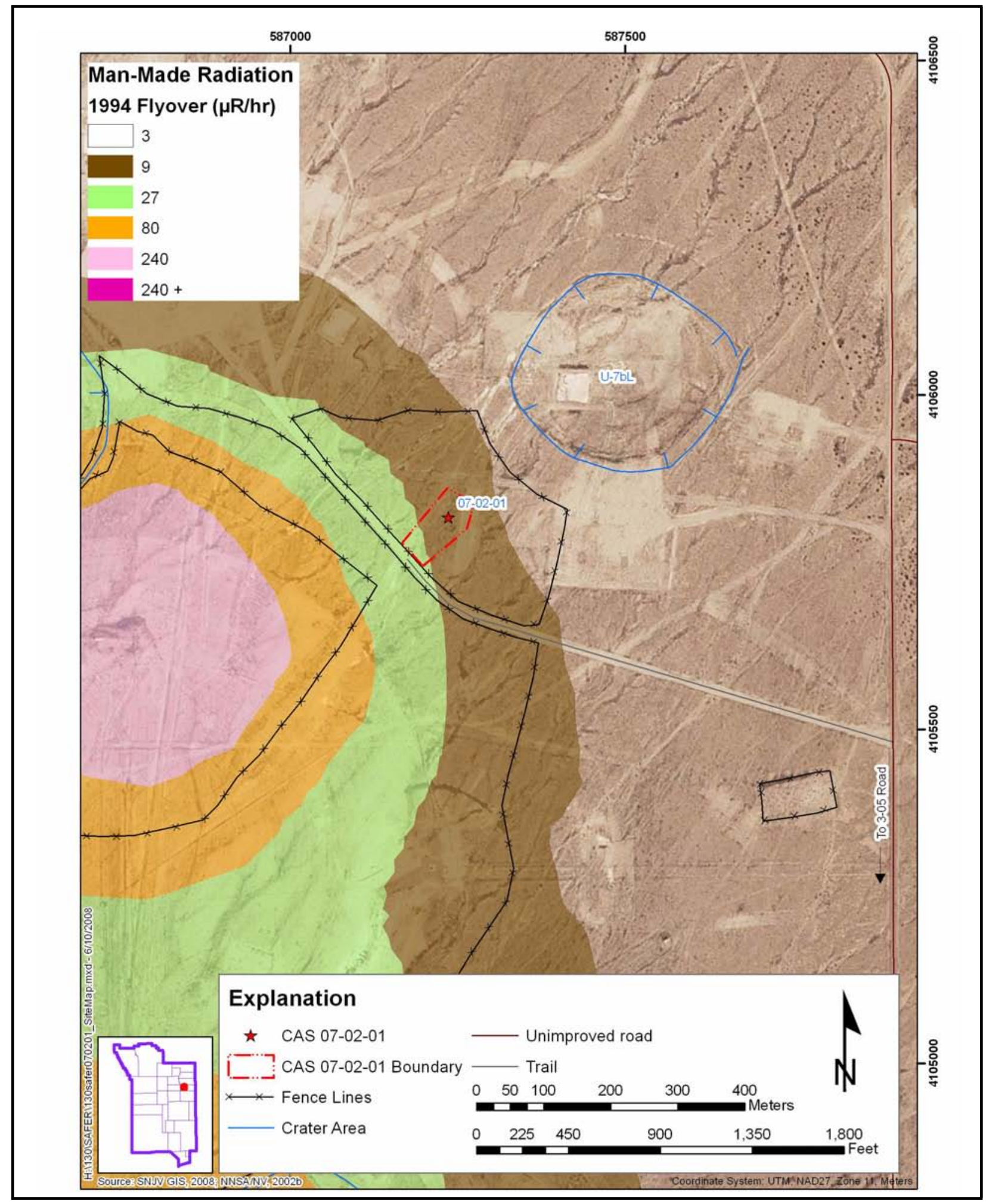

Figure 2-3

CAS 07-02-01, Underground Storage Tanks, Location with Respect to Surrounding Roads, Other Physical Features, and the Man-Made Radiation Zones 
drawing of Station 7-235 depicts a single chamber concrete structure measuring approximately 8 by 20 by 8 feet (ft) (H\&N, 1960). A personal interview reveals that the station(s) are empty, and the interviewee was not aware of any USTs in CAS 07-02-01 (Morrell, 2006).

\subsubsection{Available Characterization Information}

There are no analytical data for CAS 07-02-01. A geophysical survey conducted over approximately 12,000 square feet $\left(\mathrm{ft}^{2}\right)$ identified several anomalies. The electromagnetic sensor (EM61) as shown in Figure 2-4 detected a large anomaly, denoted “A,” which measures approximately 70 by $40 \mathrm{ft}$. Within the larger anomaly are four sub-features: “A-1,” “A-2,” “A-3,” and “A-4.” Sub-feature “A-2” correlates with the underground Station 7-235. The smaller anomaly "C" correlates with the northern soil mound of CAS 07-02-01. The geophysical survey detected small metal anomalies that resemble linear wire cables and debris (SAIC, 2003).

A radiological walkover survey was performed at CAS 07-02-01 around the potential UST locations, which encompassed approximately 47,000 $\mathrm{ft}^{2}$. No radiation detections were distinguishable from background (Nicosia, 2003). While CAS 07-02-01 is located within a posted contaminated area, the contamination is not from this CAS but is believed to be from ejected metal debris from atmospheric testing (DOE/NV, 2000). This area is also under the Soils Program.

\subsection{Corrective Action Site 10-02-01, Underground Storage Tank}

Corrective Action Site 10-02-01 is a potential release associated with a UST located in Area 10 between the U-10x and U-10k craters. The site has three pipes extending from the ground surface and a concrete pad that is covered with a thin layer of soil. Figure 2-5 shows CAS 10-02-01 with respect to surrounding roads and other physical features.

\subsubsection{Historical and Process Knowledge}

The historical and process knowledge for CAS 10-02-01 remains uncertain. There are no engineering drawings or maps identified for this site. Given the location, however, this site may have been affiliated with the testing in the area. The site could have been a transformer pad rather than a potential UST based upon the configuration of the galvanized/rigid piping extending from the ground (Madsen, 2007). 


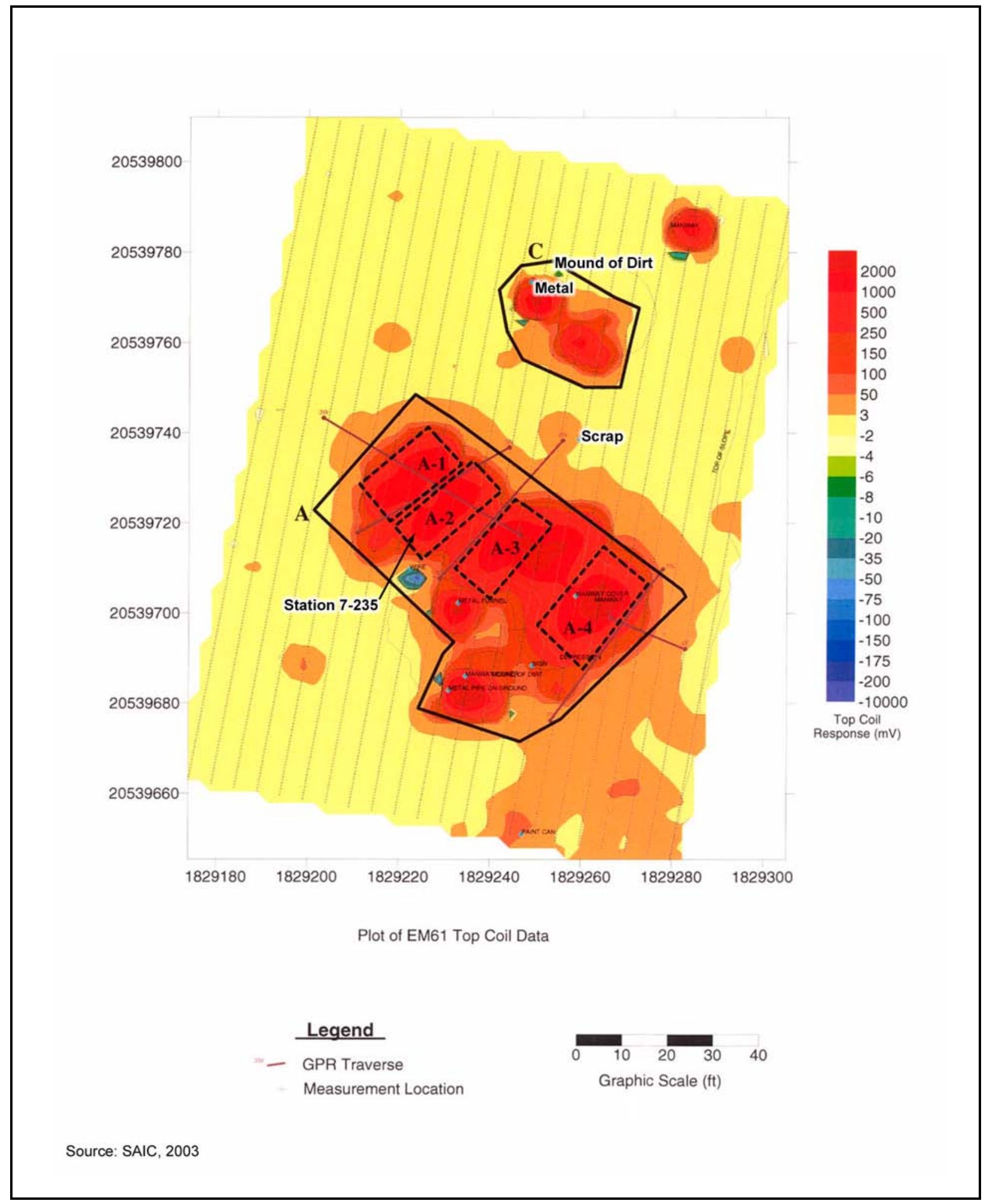

Figure 2-4

CAS 07-02-01, Underground Storage Tanks, Geophysical Survey 


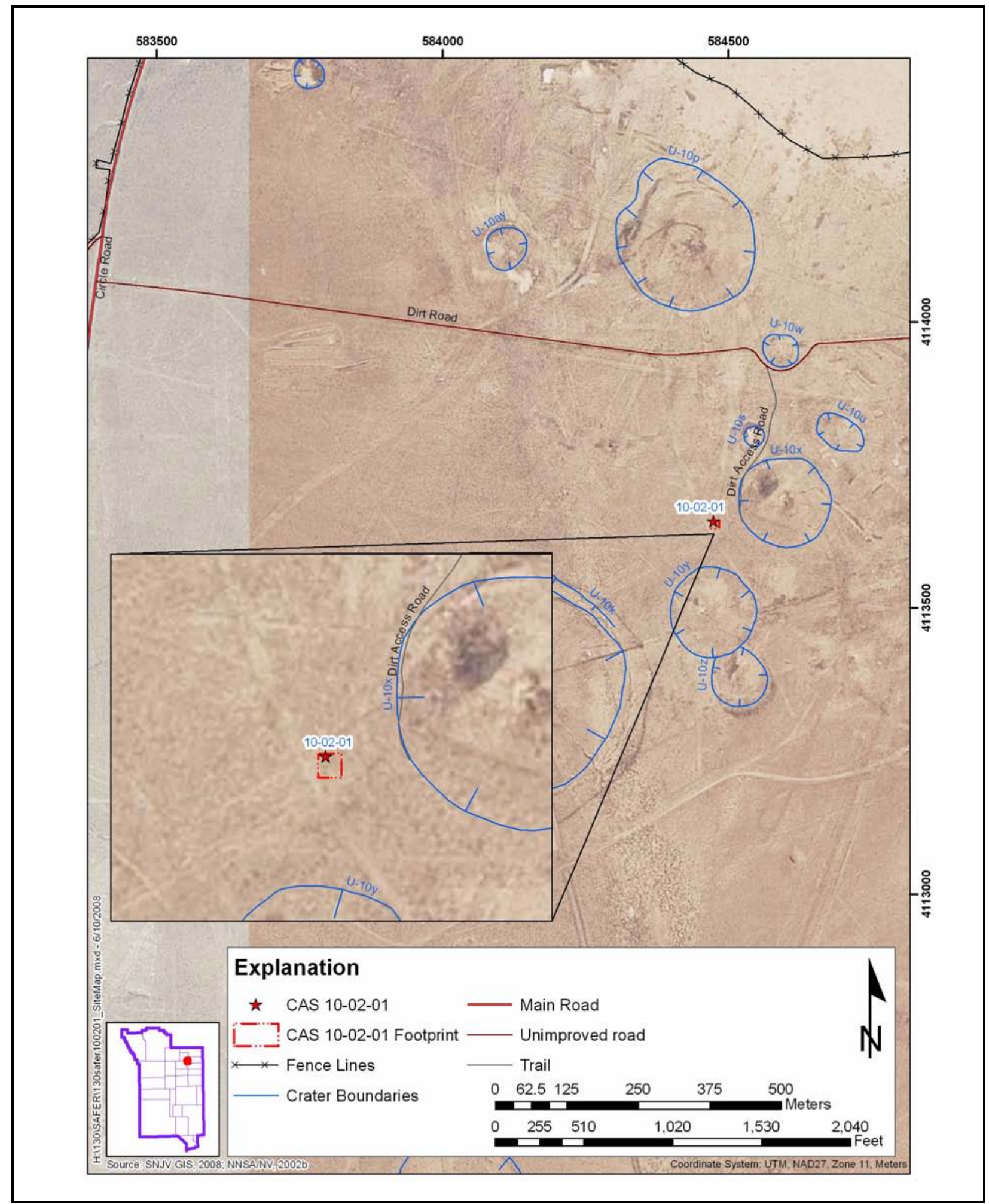

Figure 2-5

CAS 10-02-01, Underground Storage Tank, Location with Respect to Surrounding Roads and Other Physical Features 


\subsubsection{Available Characterization Information}

There are no analytical data for CAS 10-02-01. A geophysical survey was completed at the site to identify the possible location and depth of the UST and associated piping. The survey encompassed approximately 3,300 $\mathrm{ft}^{2}$. Figure 2-6 shows an anomaly approximately $25 \mathrm{ft}$ wide that was identified at the site. The anomaly is considered to be the size, geometric configuration, and magnitude consistent with a UST (SAIC, 2003).

A radiological walkover survey was performed at CAS 10-02-01 that encompassed approximately $12,500 \mathrm{ft}^{2}$. No radiation detections were distinguishable from background (Nicosia, 2003).

\subsection{Corrective Action Site 20-02-03, Underground Storage Tank}

Corrective Action Site 20-02-03 is a potential release associated with a UST located in Area 20 within the U-20az post-test cellar site. The UST is believed to be a 250-gallon (gal) gas sampling tank that was used during the post-test drillback operations of the Barnwell test. There are no surficial indications of a UST in the area (i.e., vent pipes). Figure 2-7 shows CAS 20-02-03 with respect to surrounding roads and other physical features.

\subsubsection{Historical and Process Knowledge}

Corrective Action Site 20-02-03 is located in Area 20, north of the U-20az (Barnwell) crater and west of the U-20az post-test cellar. Post-test gas sampling operations were performed by Lawrence Livermore National Laboratory. The planned engineering drawings indicate eight USTs to be installed for these operations. Because these drawings are not "as-built," they may not be accurate. Gas sampling began after the December 13, 1989, detonation of Barnwell through January 3, 1990. Upon completion of the gas-sampling operations, there were seven documented USTs excavated and moved to the Area 2 “Tank Farm” for decontamination and disposal (Author Unknown, 1994).

\subsubsection{Available Characterization Information}

There are no analytical data for CAS 20-02-03. An EM61 geophysical survey was performed at the CAS site marker location, and no anomalous features were detected. There was, however, an anomaly detected to the east of the original engineered planned location of the 250-gal UST. 


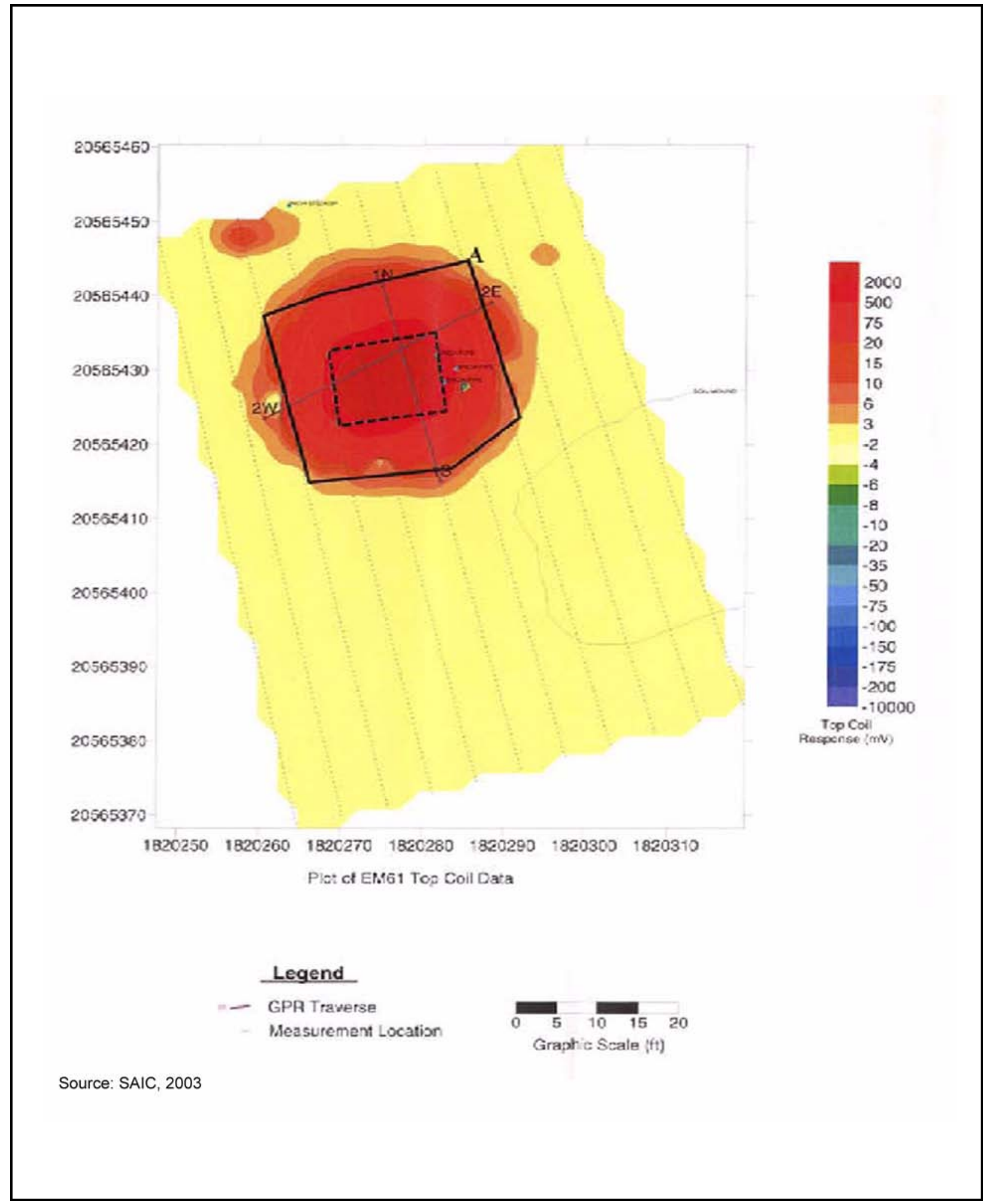

Figure 2-6

CAS 10-02-01, Underground Storage Tank, Geophysical Survey 


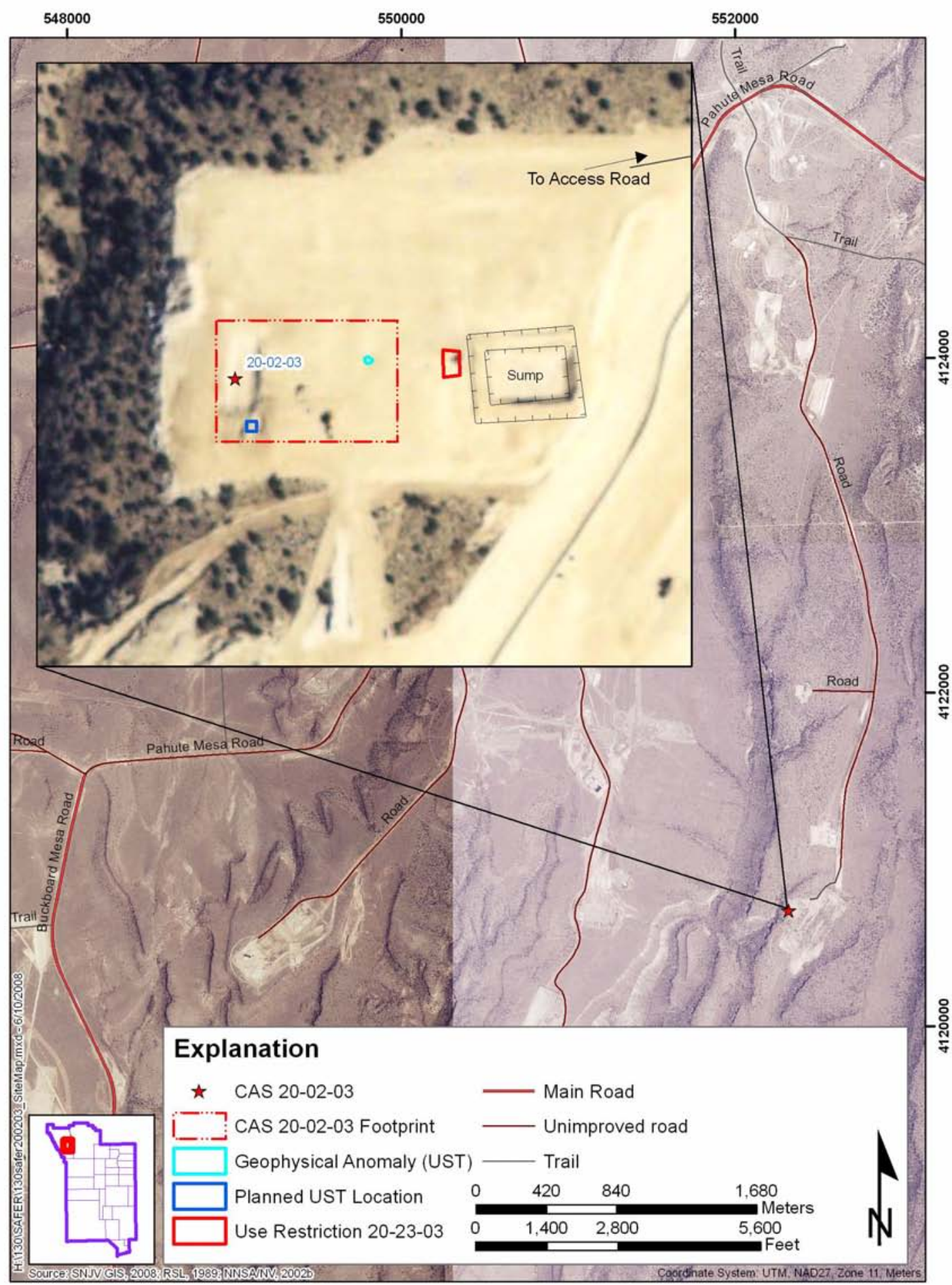

Figure 2-7

CAS 20-02-03, Underground Storage Tank, Location with Respect to Surrounding Roads and Other Physical Features 
Figure 2-8 depicts this anomaly to be very shallow, approximately $1.5 \mathrm{ft}$ below ground surface (bgs), and consistent with an approximate 250-gal UST (Fahringer, 2004).

An aerial radiological survey was performed throughout the Area 20 in 1980, and a walkover survey was performed at a nearby CAS 20-25-03 in 1997. No radiation detections were distinguishable from background (IT, 1997).

\subsection{Corrective Action Site 20-99-05, Tar Residue}

Corrective Action Site 20-99-05 consists of surface or near-surface releases associated with an area of tar residue located within the fenced boundary of the U20z potential crater. The tar residue is located approximately $500 \mathrm{ft}$ south of the U20z ground zero. The tar is a dark black, hardened, cracked, and brittle material that has a slight hydrocarbon odor. The tar is present on the ground surface in many small discontinuous areas within an approximate 40 by $30 \mathrm{ft}$ flat area where the soil consists of soft sand with a thin layer of gravel-sized pumice. The patches of tar range from approximately 0.5 to 2.0 in. thick. No soil staining was observed surrounding the tar. Figure 2-9 shows CAS 20-99-05 with respect to surrounding roads and other physical features.

\subsubsection{Historical and Process Knowledge}

Due to the location of the tar within the U20z potential crater area, it is assumed to be associated with operations that supported the Kasseri test, conducted on October 28, 1975. Original descriptions refer to the tar residue as coal tar epoxy (CTE), which was commonly used at the NTS to seal the stemming material during drilling activities.

\subsubsection{Available Characterization Information}

Corrective Action Site 20-99-05 was first categorized as a CTE spill in a letter entitled, Request for Plan on the Inventory of Inactive and Abandoned Waste Sites on the Nevada Test Site (Dickson, 1992). In this letter, REECo provided recommendations for sites listed in the Nevada Test Site Inventory of Inactive and Abandoned Facilities and Waste Sites (REECo, 1991), which included CAS 20-99-05 being reassigned a classification of CTE. A sampling and cleanup plan for CAS 20-99-05 was included in a REECo draft action plan (REECo, 1992a); however, no sampling results have been identified to support that the tar consists of CTE. 


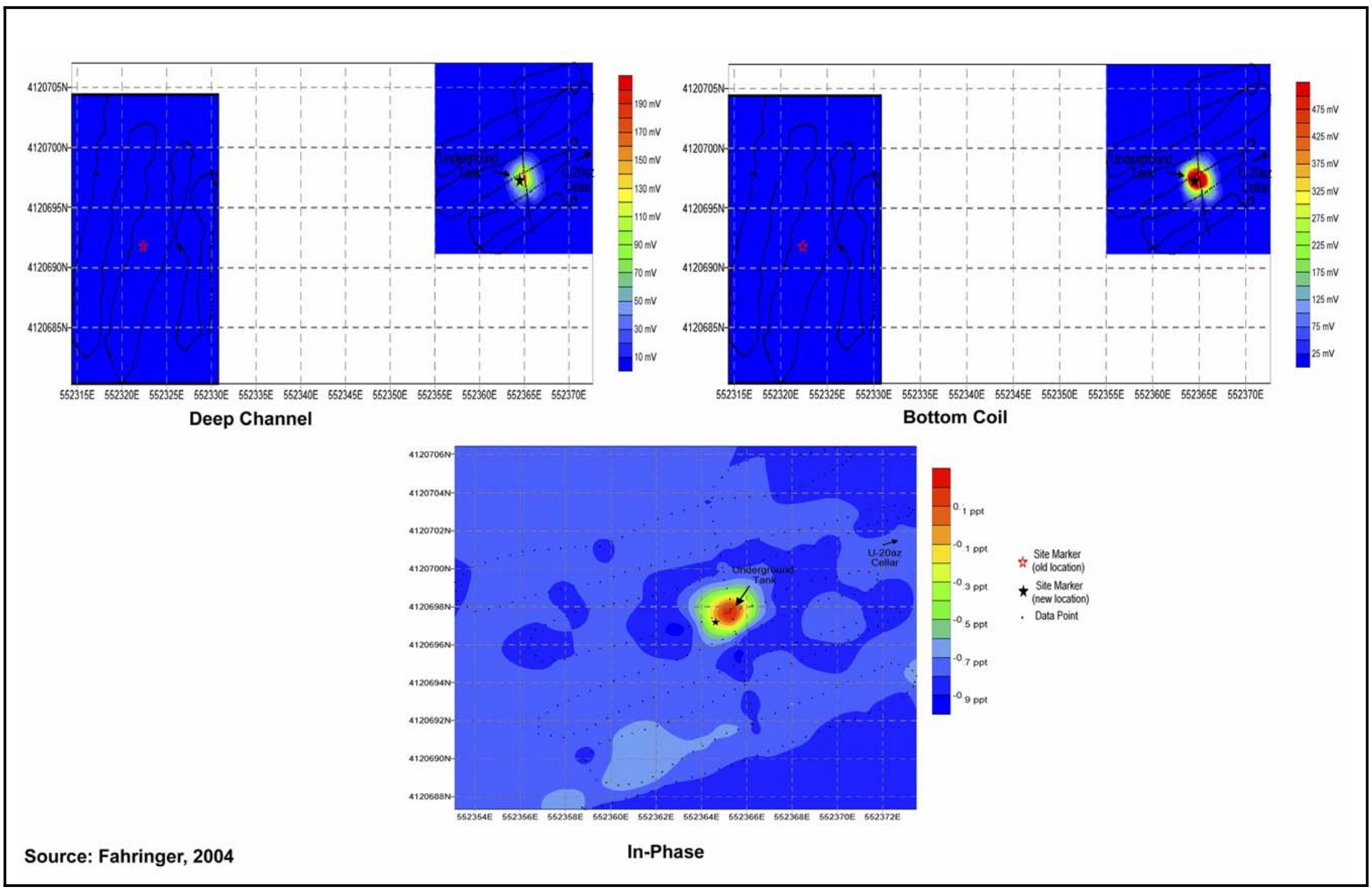

Figure 2-8

CAS 20-02-03, Underground Storage Tank, Geophysical Survey 


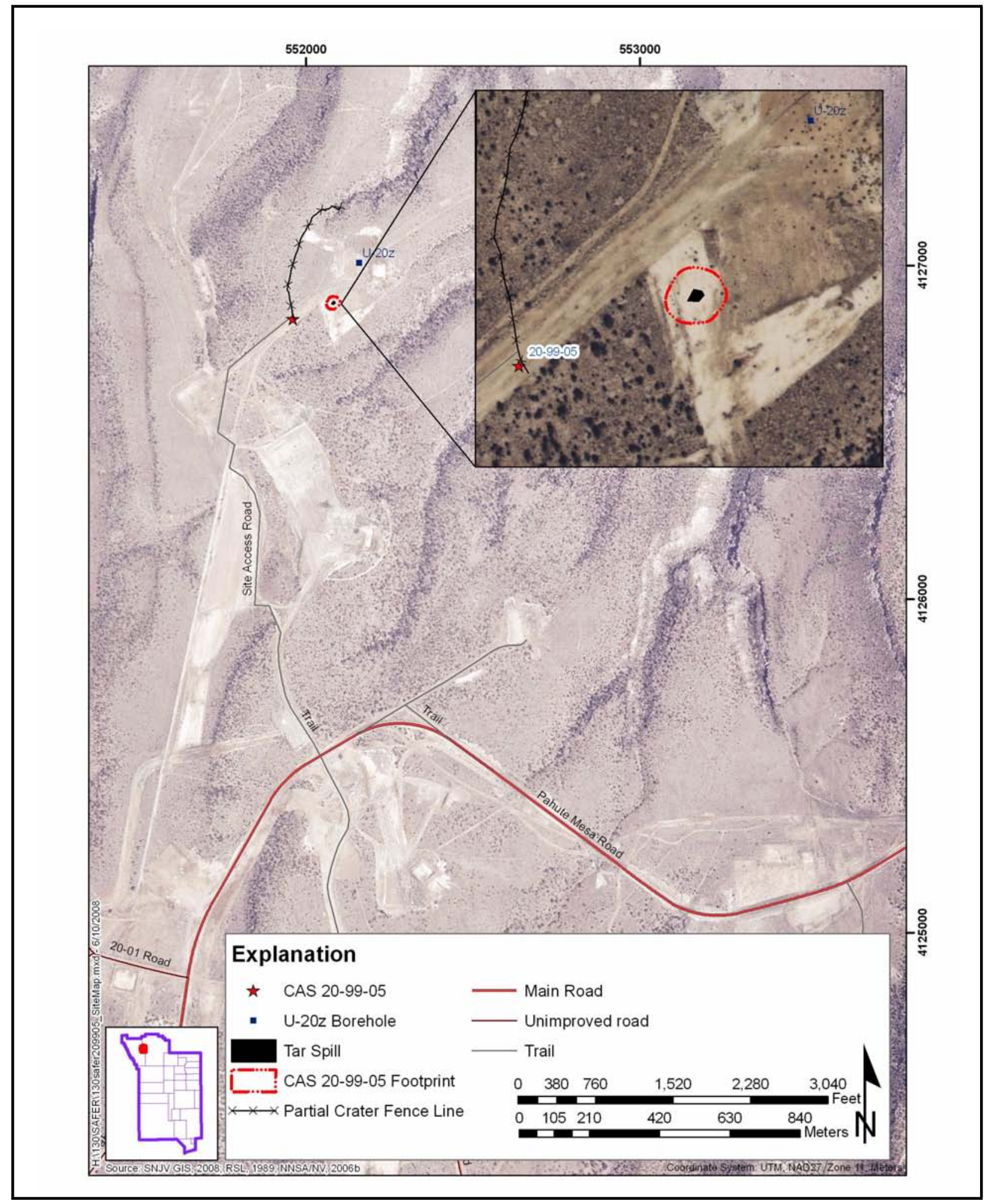

Figure 2-9

CAS 20-99-05, Tar Residue, Location with Respect to Surrounding Roads and Other Physical Features 


\subsection{Corrective Action Site 22-02-02, Buried UST Piping}

Corrective Action Site 22-02-02 is located in Area 22 at the former Camp Desert Rock. The CAS consists of potential releases associated with the buried UST piping that was connected to three 10,000-gal fuel storage tanks at the former gas station. The former tanks are not associated with this CAS. Figure 2-10 shows CAS 20-02-02 with respect to surrounding roads and other physical features.

\subsubsection{Historical and Process Knowledge}

Corrective Action Site 22-02-02 is in the former Camp Desert Rock of Area 22. Camp Desert Rock was the staging area and housing facility for military personnel involved with nuclear testing from 1951 to 1958 and Army subinstallation until 1964. This CAS has remnants of a former gas station to include a concrete island that may have been the fill station; a concrete sub-foundation, Building T-951, which may have been the former control flow room; and buried UST piping that connects the two. The gas station was serviced by three 10,000-gal tanks south of the former Building T-951 (USACE, 1994). The tank area is not within the scope of this CAS but is included in CAU 561, CAS 22-19-06, Buried Waste Disposal Site.

\subsubsection{Available Characterization Information}

There are no analytical data for CAS 22-02-02. An EM61 MK2 geophysical survey was performed at CAS 22-02-02. Figure 2-11 shows the data suggest an anomaly consistent with subsurface piping connecting the concrete island in the north-central part of the map with the concrete foundation located in the southeastern part of the survey area (Shaw, 2002).

A radiological survey was performed at CAS 22-02-02 that encompassed approximately 5,372 $\mathrm{ft}^{2}$. The data reveal that radioactivity is at or near background levels (IT, 2002).

\subsection{Corrective Action Site 23-02-07, Underground Storage Tank}

Corrective Action Site 23-02-07 is a potential release from a 2,500-gal UST located east of Warehouse 6 and north of Building 119 in Area 23. The UST is believed to have been used as a waste 


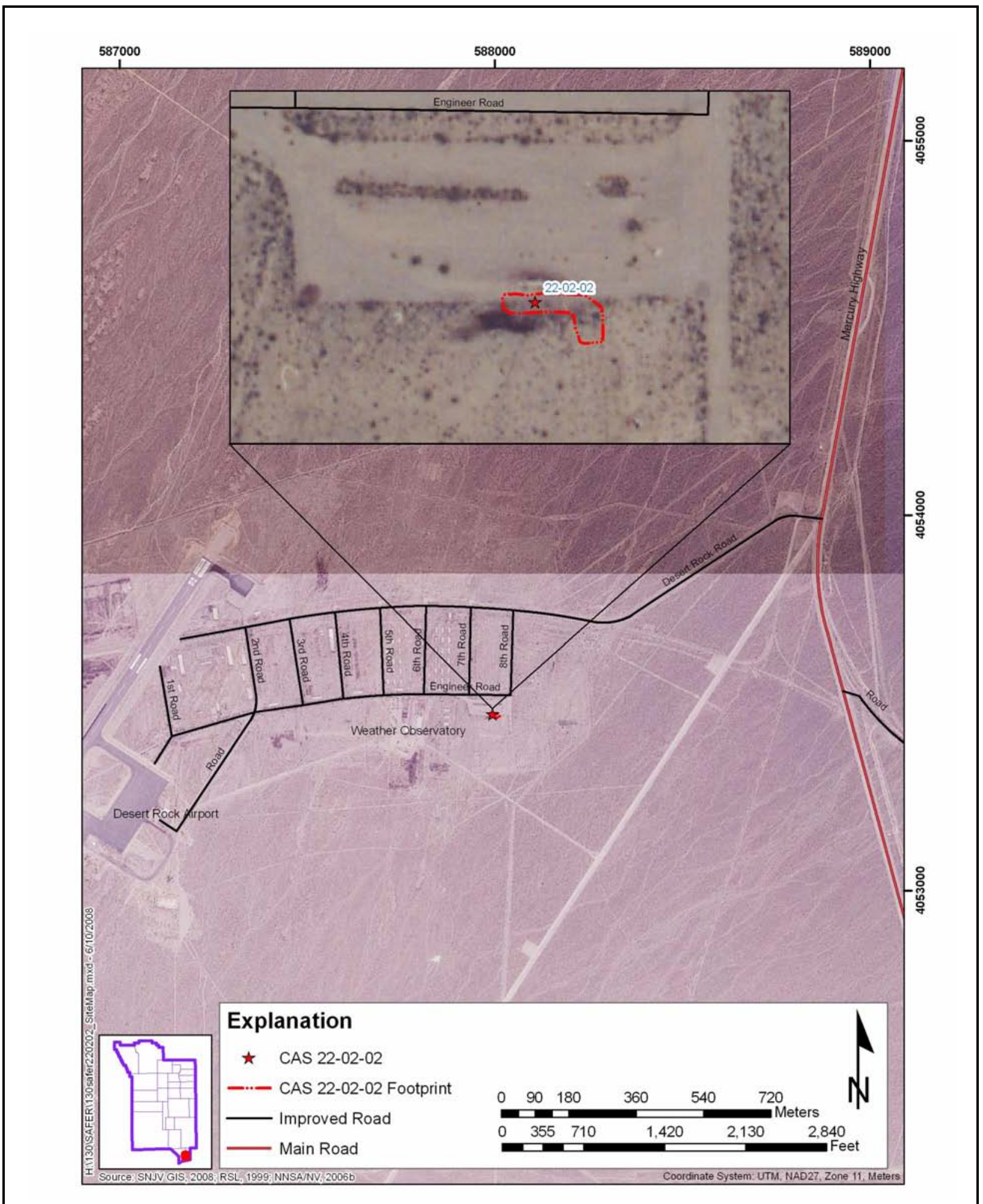

Figure 2-10

CAS 22-02-02, Buried UST Piping, Location with Respect to Surrounding Roads and Other Physical Features 


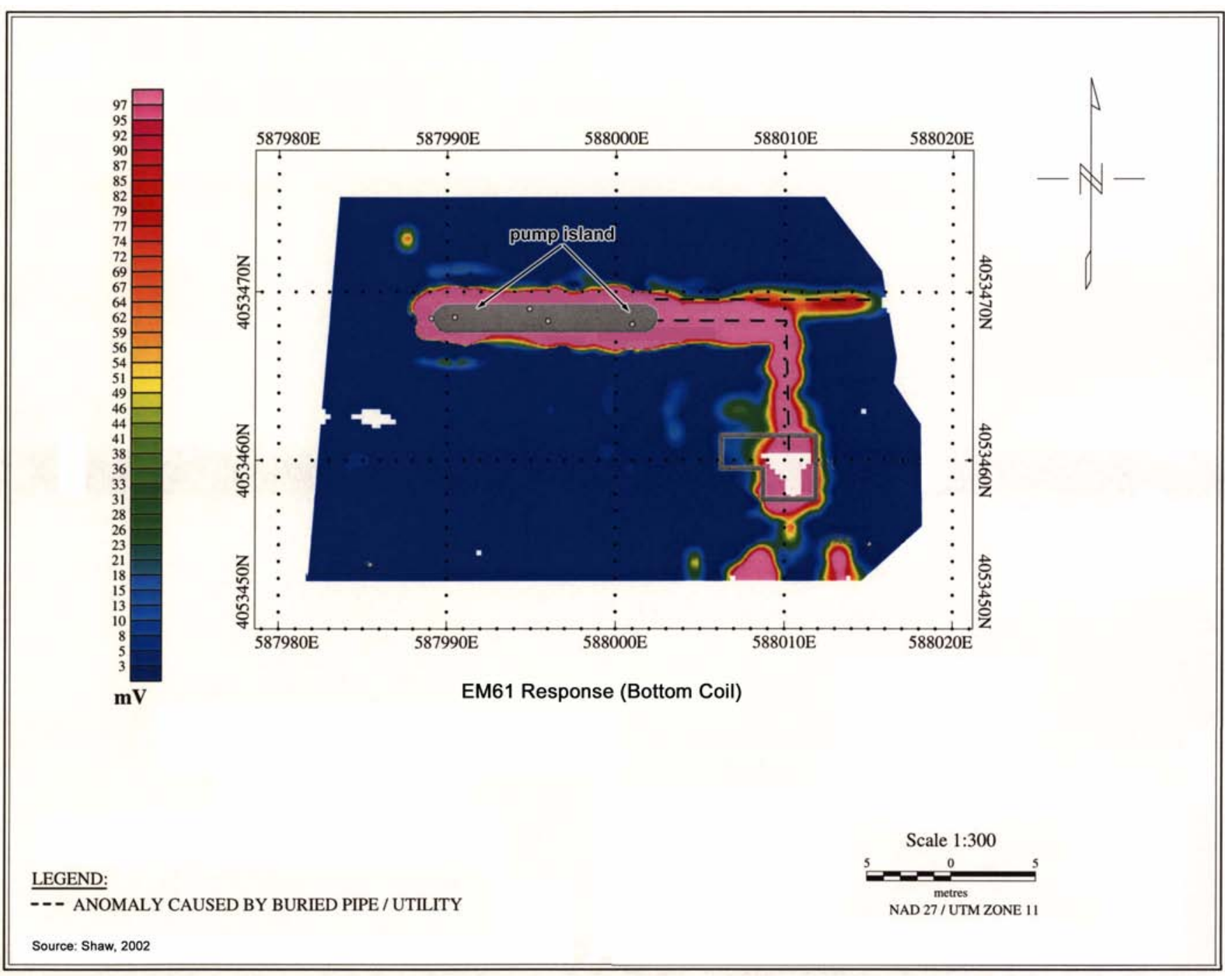

Figure 2-11

CAS 22-02-02, Buried UST Piping, Geophysical Survey 
oil storage tank. The UST is also identified as tank 23-119-1 by NDEP as closed. Figure 2-12 shows CAS 23-02-07 with respect to surrounding roads and other physical features.

\subsubsection{Historical and Process Knowledge}

Corrective Action Site 23-02-07 is located at the former gas station in Area 23 at the NTS. The CAS is described as a 2,500-gal UST (tank 23-119-1) used to store waste oil. The UST is registered as being filled with cement grout and closed in place in 1990 (REECo, 1992b).

\subsubsection{Available Characterization Information}

There are analytical data for CAS 23-02-07. A “Notification to Nevada Division of Environmental Protection (NDEP) of Tank Closures and Upgrades" states that samples were taken below the base of the tank. One sample from tank 23-119-1 indicated that the total petroleum hydrocarbons (TPH) concentration was 117 milligrams per kilogram (mg/kg). The records state that NDEP approved leaving the tank in place upon removing its contents, rinsing the tank, grouting the tank with cement, then backfilling and leaving the location to its original state (Haworth, 1990). 


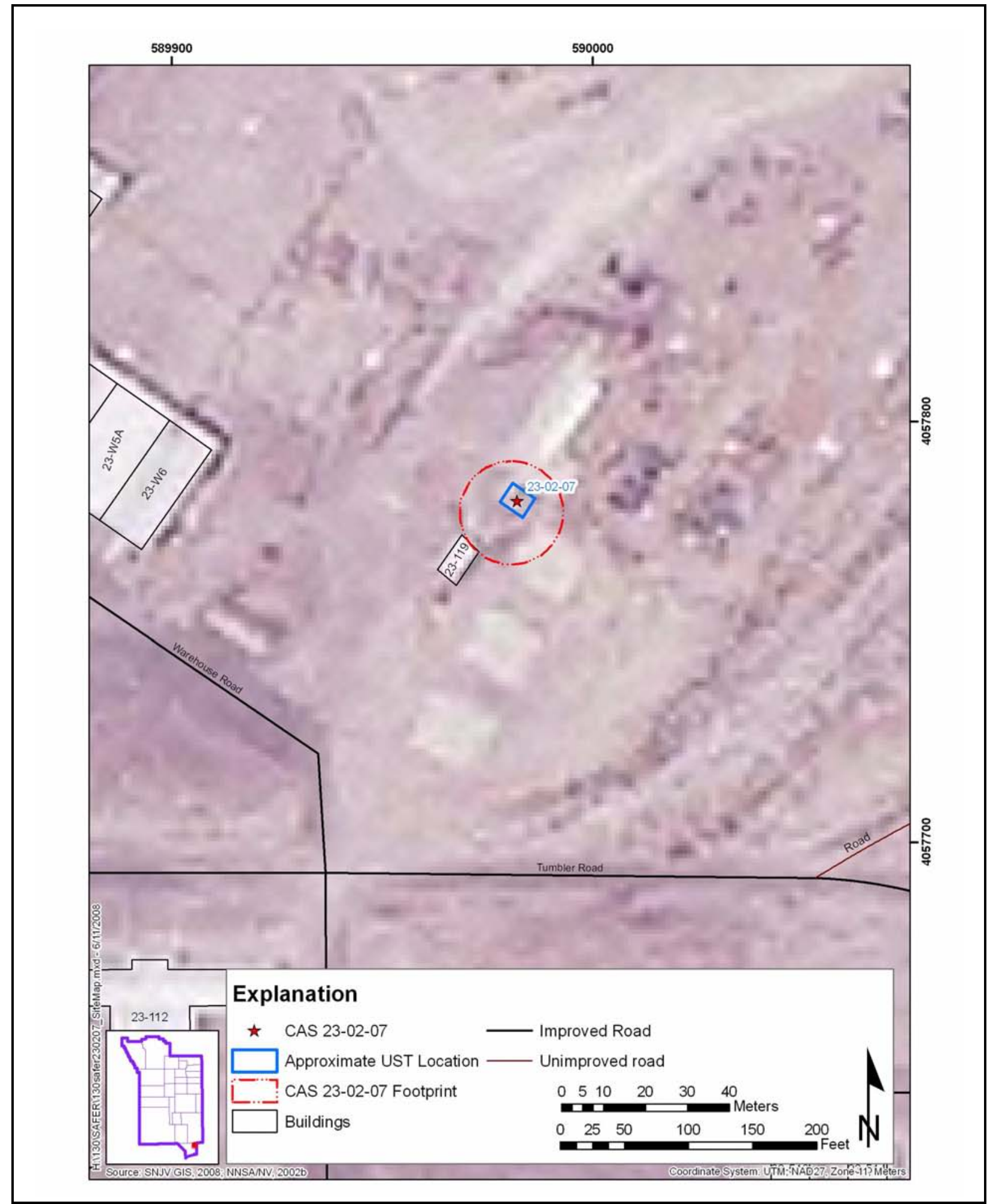

Figure 2-12

CAS 23-02-07, Underground Storage Tank, Location with Respect to Surrounding Roads and Other Physical Features 


\subsection{Data Quality Objectives}

\subsection{Summary of DQO Analysis}

This section contains a summary of the DQO process that is presented in Appendix B. The DQO process is a strategic planning approach based on the scientific method that is designed to ensure that the data collected will provide sufficient and reliable information to identify, evaluate, and technically defend the recommendation of viable corrective actions (e.g., no further action, clean closure, or closure in place).

The DQO strategy for CAU 130 was developed at a meeting on April 3, 2008. The DQOs were developed to identify data needs, clearly define the intended use of the environmental data, and design a data collection program that will satisfy these purposes. During the DQO discussions for this CAU, the informational inputs or data needs to resolve problem statements and decision statements were documented.

The problem statement for CAU 130 is: "Existing information on the nature and extent of potential contamination is insufficient to validate the assumptions used to select the corrective actions or to verify that closure objectives were met for the CASs in CAU 130.” To address this question, the resolution of two decisions statements is required:

- Decision I: “Is any COC present in environmental media?” For the judgmental sampling design, any analytical result for a COPC above the FAL will result in that COPC being designated as a COC. For the probabilistic sampling design, any COPC that has a 95 percent upper confidence limit (UCL) of the average exceeding the FAL, will result in that COPC being designated as a COC.

- Decision II: "Is sufficient information available to confirm that closure objectives were met?" Sufficient information is defined to include:

- Identifying the lateral and vertical extent of COC contamination in media, if present

- The information needed to characterize IDW for disposal

- The information needed to determine remediation waste types 
The presence of a COC would require a corrective action. A corrective action may also be necessary if there is a potential for wastes that are present at a site to impose COCs into site environmental media if the wastes were to be released. To evaluate the potential for site wastes to result in the introduction of a COC to the surrounding environmental media, the following conservative assumptions were made:

- Any containment of the wastes would fail at some point, and the wastes would be released to the surrounding media.

- The resulting concentration of contaminants in the surrounding media would be equal to the concentration of contaminants in the waste.

- Any liquid waste contaminant concentrations exceeding the Resource Conservation and Recovery Act (RCRA) toxicity characteristic concentration would result in COCs in the surrounding media.

Waste solids containing a contaminant exceeding an equivalent FAL concentration would be considered to be potential source material (PSM) and would require a corrective action. Waste liquids with contaminant concentrations exceeding an equivalent toxicity characteristic action level would be considered to be PSM and would require a corrective action.

Decision I samples will be submitted to analytical laboratories for the analyses listed in Table 3-1. The constituents reported for each analytical method are listed in Table 3-2.

The list of COPCs is intended to encompass all of the contaminants that could potentially be present at each CAS. These COPCs were identified during the planning process through the review of site history, process knowledge, personal interviews, past investigation efforts (where available), and inferred activities associated with the CASs. Contaminants detected at other similar or other NTS sites were also included in the COPC list to reduce the uncertainty about potential contamination at the CASs because complete information regarding activities performed at the CAU 130 sites is not available. 
Table 3-1

\section{Analytical Program ${ }^{a}$}

(Includes Waste Characterization Analyses)

\begin{tabular}{|c|c|c|c|c|c|c|c|}
\hline Analyses & $\begin{array}{c}\text { CAS } \\
01-02-01\end{array}$ & \begin{tabular}{|c|} 
CAS \\
$07-02-01$
\end{tabular} & $\begin{array}{c}\text { CAS } \\
10-02-01\end{array}$ & $\begin{array}{c}\text { CAS } \\
20-02-03\end{array}$ & $\begin{array}{c}\text { CAS } \\
20-99-05\end{array}$ & $\begin{array}{c}\text { CAS } \\
22-02-02\end{array}$ & $\begin{array}{c}\text { CAS } \\
23-02-07\end{array}$ \\
\hline \multicolumn{8}{|c|}{ Organic Contaminants of Potential Concern (COPCs) } \\
\hline Volatile Organic Compounds & $\mathrm{X}$ & $\mathrm{X}$ & $\mathrm{X}$ & $\mathrm{X}$ & $\mathrm{X}$ & $\mathrm{X}$ & $\mathrm{X}$ \\
\hline Semivolatile Organic Compounds & $\mathrm{X}$ & $\mathrm{X}$ & $\mathrm{X}$ & $\mathrm{X}$ & $\mathrm{X}$ & $\mathrm{X}$ & $\mathrm{X}$ \\
\hline $\begin{array}{l}\text { Total Petroleum Hydrocarbons- } \\
\text { Gasoline-Range Organics }\end{array}$ & $\mathrm{X}$ & $\mathrm{X}$ & 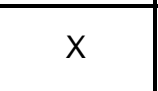 & $\mathrm{X}$ & -- & $\mathrm{X}$ & $\mathrm{X}$ \\
\hline $\begin{array}{l}\text { Total Petroleum Hydrocarbons- } \\
\text { Diesel-Range Organics }\end{array}$ & $\mathrm{X}$ & $\mathrm{X}$ & $\mathrm{X}$ & $\mathrm{X}$ & $\mathrm{X}$ & $\mathrm{X}$ & $\mathrm{X}$ \\
\hline Polychlorinated Biphenyls & -- & $\mathrm{x}$ & $\mathrm{X}$ & -- & -- & -- & $x$ \\
\hline \multicolumn{8}{|c|}{ Inorganic COPCs } \\
\hline $\begin{array}{c}\text { Resource Conservation and Recovery Act } \\
\text { Metals }\end{array}$ & $x$ & $x$ & $x$ & $x$ & $x$ & $x$ & $x$ \\
\hline \multicolumn{8}{|c|}{ Radionuclide COPCs } \\
\hline$\overline{\text { Gamma Spectroscopy }^{b}}$ & $\overline{\mathrm{X}}$ & $\overline{\mathrm{X}}$ & $\overline{\mathrm{X}}$ & $\overline{\mathrm{X}}$ & $\overline{-1-}$ & $\overline{\mathrm{X}}$ & $\overline{\mathrm{X}}$ \\
\hline \multicolumn{8}{|c|}{ Waste Characterization Analyses (if necessary) } \\
\hline$\overline{\text { TCLP VOCS }}$ & $\overline{\mathrm{X}}$ & $\overline{\mathrm{X}}$ & $\overline{\bar{X}}$ & $\overline{\mathrm{X}}$ & $\overline{\bar{X}}$ & $\overline{\mathrm{X}}$ & $\overline{\bar{X}}$ \\
\hline TCLP SVOCS & $\mathrm{X}$ & $x$ & $\mathrm{x}$ & $x$ & $\mathrm{x}$ & $\mathrm{x}$ & $\mathrm{x}$ \\
\hline TCLP RCRA Metals & $\mathrm{X}$ & $x$ & $\mathrm{x}$ & $x$ & $\mathrm{x}$ & $x$ & $\mathrm{X}$ \\
\hline Total Pesticides & $\mathrm{X}$ & $\mathrm{X}$ & $\mathrm{X}$ & $\mathrm{X}$ & $\mathrm{X}$ & $\mathrm{X}$ & $\mathrm{X}$ \\
\hline Total Herbicides & $\mathrm{x}$ & $\mathrm{x}$ & $\mathrm{X}$ & $\mathrm{x}$ & $\mathrm{X}$ & $\mathrm{x}$ & $\mathrm{X}$ \\
\hline PCBS & $x$ & $x$ & $\mathrm{X}$ & $x$ & $\mathrm{X}$ & $x$ & $\mathrm{X}$ \\
\hline TPH-DRO & $x$ & $x$ & $\mathrm{x}$ & $x$ & $\mathrm{X}$ & $x$ & $\bar{x}$ \\
\hline TPH-GRO & $x$ & $x$ & $x$ & $x$ & $\mathrm{x}$ & $x$ & $x$ \\
\hline Gamma Spectroscopy & $\mathrm{X}$ & $x$ & $\mathrm{X}$ & $x$ & $x$ & $x$ & $\mathrm{X}$ \\
\hline Isotopic Uranium & $x$ & $x$ & $\mathrm{x}$ & $x$ & $\bar{x}$ & $x$ & $\bar{x}$ \\
\hline Isotopic Plutonium & $\mathrm{X}$ & $x$ & $\mathrm{X}$ & $\mathrm{X}$ & $\mathrm{X}$ & $x$ & $\mathrm{X}$ \\
\hline Strontium-90 & $x$ & $\mathrm{X}$ & $\mathrm{X}$ & $\mathrm{X}$ & $x$ & $x$ & $x$ \\
\hline Gross Alpha/Gross Beta $^{c}$ & $\mathrm{X}$ & $\mathrm{X}$ & $\mathrm{X}$ & $\mathrm{X}$ & $\mathrm{X}$ & $\mathrm{X}$ & $\mathrm{X}$ \\
\hline Tritium $^{c}$ & $x$ & $x$ & $x$ & $\mathrm{x}$ & $x$ & $x$ & $\mathrm{X}$ \\
\hline
\end{tabular}

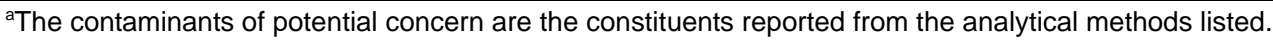

${ }^{b}$ Results of gamma analysis will be used to determine whether further radioanalytical analysis is warranted.

${ }^{c} \mathrm{Gross}$ alpha/gross beta and tritium will only be taken on decontamination rinsate.

DRO = Diesel-range organics

$\mathrm{GRO}=$ Gasoline-range organics

$\mathrm{PCB}=$ Polychlorinated biphenyl

RCRA = Resource Conservation and Recovery Act

$\mathrm{X}=$ Required analytical method

$--=$ Not required
SVOC $=$ Semivolatile organic compound

TCLP = Toxicity Characteristic Leaching Procedure

VOC $=$ Volatile organic compound 
Table 3-2

Constituents Reported by Analytical Methods

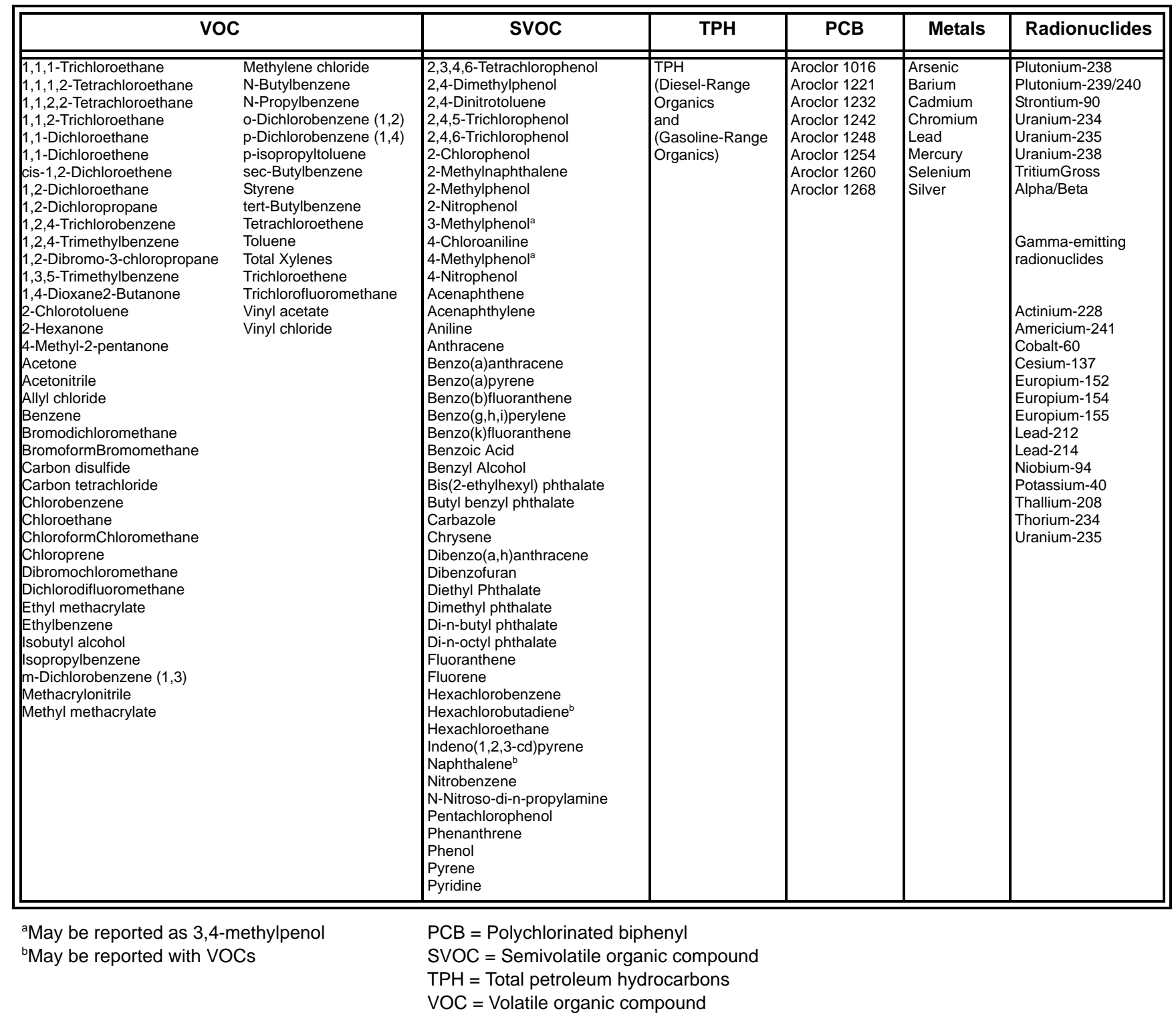

Analysis for polychlorinated biphenyls (PCBs) is not planned for CAS 01-02-01, CAS 20-02-03, or CAS 22-02-02. Analysis for PCBs, gamma spectroscopy, or TPH-gasoline-range organics is not planned for CAS 20-99-05. This is based on process knowledge, previous analyses, and the information about the types of materials (and potentially released) at each CAS. Corrective Action Site 01-02-01 was associated with a pipe labeled "GAS” and is believed to be natural, manufactured, or liquefied petroleum gas, and PCBs are not components of these materials. Corrective Action Site 20-02-03 is post-test gas sampling tank used during drill back operations and was not used to 
collect material potentially containing PCBs. Corrective Action Site 22-02-02 is associated with the Camp Desert Rock gas station fuel tanks and PCBs have not been reported to be present in gasoline in the past. Corrective Action Site 20-99-05 consists of a tar-like material believed to be a type of CTE. This type of material has been analyzed previously at other CAUs using these methods and the results have indicated that there has been no radiological, metal or PCB contaminants identified at concentrations exceeding preliminary action levels (PALs) in any sample. Therefore, no COPCs were identified during the DQO process for these CASs that would require these analyses.

During the review of site history documentation, process knowledge information, personal interviews, past investigation efforts (where available), and inferred activities associated with the CASs, some of the COPCs were identified as targeted contaminants at specific CASs. Targeted contaminants are those COPCs for which evidence in the available site and process information suggests that they may be reasonably suspected to be present at a given CAS. The targeted contaminants are required to meet a more stringent completeness criteria than other COPCs, thus providing greater protection against a decision error. Targeted contaminants for each CAU 130 CAS are identified in Table 3-3.

Table 3-3

Targeted Analytes for CAU 130

\begin{tabular}{||c|c|c||}
\hline Corrective Action Site & Chemical Targeted Analytes & Radiological Targeted Analytes \\
\hline \hline $01-02-01$ & VOCs, SVOCs & None \\
\hline $07-02-01$ & Lead (associated with lead brick[s]) & None \\
\hline $10-02-01$ & None & None \\
\hline $20-02-03$ & None & None \\
\hline $20-99-05$ & VOCs, SVOCs & None \\
\hline $22-02-02$ & $\begin{array}{c}\text { VOCs, SVOCs, Lead } \\
\text { (associated with leaded gasoline) }\end{array}$ & None \\
\hline $23-02-07$ & VOCs, SVOCs & None \\
\hline
\end{tabular}

SVOC $=$ Semivolatile organic compound $\mathrm{VOC}=$ Volatile organic compound 
Decision II samples will be submitted for the analysis of all unbounded COCs. In addition, samples will be submitted for analyses as needed to support waste management or health and safety decisions.

The data quality indicators (DQIs) of precision, accuracy, representativeness, completeness, comparability, and sensitivity needed to satisfy DQO requirements are discussed in Section 7.2. Laboratory data will be assessed in the CR to confirm or refute the CSM and determine whether the DQO data needs were met.

To satisfy the DQI of sensitivity (presented in Section 7.2.6), the analytical methods must be sufficient to detect contamination that is present in the samples at concentrations equal to the corresponding FALs. Analytical methods and minimum detectable concentrations (MDCs) for each CAU 130 COPC are provided in Tables 3-4 and 3-5. The MDC is the lowest concentration of a chemical or radionuclide that can be detected in a sample within an acceptable level of error. Due to changes in analytical methodology and changes in analytical laboratory contracts, information in Tables 3-4 and 3-5 that varies from corresponding information in the Quality Assurance Project Plan (QAPP) will supersede that information in the QAPP (NNSA/NV, 2002a). 
Table 3-4

Analytical Requirements for Radionuclides for CAU 130

\begin{tabular}{|c|c|c|c|c|c|}
\hline Analysis $^{a}$ & Matrix & $\begin{array}{c}\text { Analytical } \\
\text { Method }\end{array}$ & $\begin{array}{c}\text { Minimum } \\
\text { Detectable } \\
\text { Concentration } \\
\text { (MDC) }^{\text {b }}\end{array}$ & $\begin{array}{c}\text { Laboratory } \\
\text { Precision }\end{array}$ & $\begin{array}{l}\text { Laboratory } \\
\text { Accuracy } \\
\text { (\%R) }\end{array}$ \\
\hline \multicolumn{6}{|c|}{ Gamma-Emitting Radionuclides } \\
\hline \multirow[b]{2}{*}{$\begin{array}{c}\text { Gamma } \\
\text { Spectroscopy }\end{array}$} & $\overline{\text { Aqueous }}$ & EPA $901.1^{\mathrm{c}}$ & \multirow[b]{2}{*}{$\begin{array}{l}<\text { Preliminary } \\
\text { Action Levels }\end{array}$} & RPD & \multirow[b]{2}{*}{$\begin{array}{l}\text { Laboratory Control } \\
\text { Sample } \\
80-120 \% R\end{array}$} \\
\hline & Nonaqueous & HASL-300 ${ }^{f}$ & & $\begin{array}{c}35 \% \\
N D^{\mathrm{e}} \\
-2<N D^{\mathrm{e}}<2\end{array}$ & \\
\hline \multicolumn{6}{|c|}{ Other Radionuclides } \\
\hline \multirow[b]{2}{*}{ Tritium } & Aqueous & EPA 906.0 & \multirow{10}{*}{$\begin{array}{l}<\text { Preliminary } \\
\text { Action Levels }\end{array}$} & \multirow{10}{*}{$\begin{array}{c}\mathrm{RPD} \\
35 \%^{\mathrm{d}} \\
\mathrm{ND}^{\mathrm{e}} \\
-2<\mathrm{ND}^{\mathrm{e}}<2\end{array}$} & \multirow[b]{2}{*}{$\begin{array}{l}\text { Laboratory Control } \\
\text { Sample } \\
80-120 \% R\end{array}$} \\
\hline & Nonaqueous & $\begin{array}{c}\text { Approved } \\
\text { Laboratory } \\
\text { Procedure }^{g}\end{array}$ & & & \\
\hline Gross Alpha & All & EPA $900.0^{c}$ & & & \multirow{4}{*}{$\begin{array}{c}\text { Chemical Yield } \\
\text { 30-105\%R } \\
\text { (not applicable for } \\
\text { tritium and } \\
\text { gross-alpha/beta) }\end{array}$} \\
\hline Gross Beta & All & EPA $900.0^{c}$ & & & \\
\hline Plutonium-238 & All & HASL-300 & & & \\
\hline Plutonium-239/240 & All & HASL-300 & & & \\
\hline Strontium-90 & All & HASL-300 & & & \multirow{4}{*}{$\begin{array}{c}\text { Matrix Spike Sample } \\
61-140 \% \mathrm{R} \\
\text { (tritium and gross } \\
\text { alpha/beta only) }\end{array}$} \\
\hline Uranium-234 & All & HASL-300 & & & \\
\hline Uranium-235 & All & HASL-300 & & & \\
\hline Uranium-238 & All & HASL-300 & & & \\
\hline
\end{tabular}

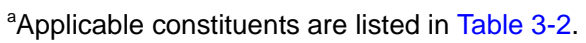

${ }^{\mathrm{b}}$ The MDC is the lowest concentration of a radionuclide present in a sample and can be detected with a 95\% confidence level.

${ }^{\mathrm{C}}$ Prescribed Procedures for Measurement of Radioactivity in Drinking Water (EPA, 1980)

${ }^{\mathrm{d} S}$ Sampling and Analysis Plan (Field Sampling Plan and Quality Assurance Project Plan) with Guidance (EPA, 2002)

${ }^{\text {eND }}$ is not RPD; rather, it is another measure of precision used to evaluate duplicate analyses. The ND is calculated as the difference between two results divided by the square root of the sum of the squares of their total propagated uncertainties. Evaluation of Radiochemical Data Usability (Paar and Porterfield, 1997)

${ }^{\mathrm{f}}$ The Procedures Manual of the Environmental Measurements Laboratory, HASL-300 (DOE, 1997)

${ }^{9}$ Laboratory procedure must be approved by appropriate project personnel.

EPA $=$ U.S. Environmental Protection Agency

HASL $=$ Health and Safety Laboratory

$\mathrm{ND}=$ Normalized difference

$\mathrm{RPD}=$ Relative percent difference

$\% \mathrm{R}=$ Percent recovery 
Table 3-5

Analytical Requirements for Chemical COPCs for CAU 130

\begin{tabular}{|c|c|c|c|c|c|}
\hline Analysis $^{a}$ & Matrix & $\begin{array}{l}\text { Analytical } \\
\text { Method } \\
(\mathrm{SW-846)})^{\mathrm{b}}\end{array}$ & $\begin{array}{c}\text { Minimum } \\
\text { Detectable } \\
\text { Concentration } \\
\text { (MDC) }^{\mathrm{c}}\end{array}$ & $\begin{array}{l}\text { Laboratory } \\
\text { Precision }\end{array}$ & $\begin{array}{c}\text { Laboratory } \\
\text { Accuracy } \\
\text { (\%R) }\end{array}$ \\
\hline \multicolumn{6}{|c|}{ ORGANICS } \\
\hline $\begin{array}{l}\text { Total Volatile Organic } \\
\text { Compounds }\end{array}$ & All & $8260 B$ & $\begin{array}{l}<\text { Preliminary } \\
\text { Action Levels }\end{array}$ & Lab-specific $^{d}$ & Lab-specific $^{d}$ \\
\hline $\begin{array}{l}\text { TCLP Volatile Organic } \\
\text { Compounds }\end{array}$ & Leachate & 1311/8260B & $\begin{array}{l}\leq \text { Regulatory } \\
\text { Limits }\end{array}$ & Lab-specific $^{d}$ & Lab-specific $^{d}$ \\
\hline $\begin{array}{l}\text { Total Semivolatile Organic } \\
\text { Compounds }\end{array}$ & All & $8270 \mathrm{C}$ & $\begin{array}{l}<\text { Preliminary } \\
\text { Action Levels }\end{array}$ & Lab-specific $^{d}$ & Lab-specific $^{d}$ \\
\hline $\begin{array}{l}\text { TCLP Semivolatile Organic } \\
\text { Compounds }\end{array}$ & Leachate & 1311/8270C & $\begin{array}{l}\leq \text { Regulatory } \\
\text { Limits }\end{array}$ & Lab-specific $^{d}$ & Lab-specific ${ }^{d}$ \\
\hline Polychlorinated Biphenyls & All & 8082 & \multirow{3}{*}{$\begin{array}{l}<\text { Preliminary } \\
\text { Action Levels }\end{array}$} & Lab-specific $^{d}$ & Lab-specific $^{d}$ \\
\hline $\begin{array}{l}\text { Total Petroleum Hydrocarbons- } \\
\text { Gasoline-Range Organics }\end{array}$ & All & $\begin{array}{c}\text { 8015B } \\
\text { (modified) }\end{array}$ & & Lab-specific $^{d}$ & Lab-specific $^{d}$ \\
\hline $\begin{array}{l}\text { Total Petroleum Hydrocarbons- } \\
\text { Diesel-Range Organics }\end{array}$ & All & $\begin{array}{c}\text { 8015B } \\
\text { (modified) }\end{array}$ & & Lab-specific $^{d}$ & Lab-specific $^{d}$ \\
\hline \multicolumn{6}{|c|}{ INORGANICS } \\
\hline RCRA Metals & All & $6010 \mathrm{~B}$ & $\begin{array}{l}<\text { Preliminary } \\
\text { Action Levels }\end{array}$ & \multirow{4}{*}{$\begin{array}{c}\text { RPD } \\
35 \% \\
\text { (nonaqueous) }^{\mathrm{e}} \\
20 \% \text { (aqueous) }^{\mathrm{e}} \\
\text { Absolute }^{\mathrm{D}} \\
\text { Difference }^{\mathrm{f}} \pm 2 \mathrm{x} \\
\mathrm{RL} \text { (nonaqueous) }^{\mathrm{f}} \\
\pm 1 \times \mathrm{RL} \text { (aqueous) }^{\mathrm{f}}\end{array}$} & \multirow{4}{*}{$\begin{array}{c}\text { Matrix Spike } \\
\text { Sample } \\
75-125 \% R^{b} \\
\text { Laboratory } \\
\text { Control } \\
\text { Sample } \\
80-120 \% R^{f}\end{array}$} \\
\hline TCLP Metals & Leachate & 1311/6010B & $\begin{array}{l}\leq \text { Regulatory } \\
\text { Limits }\end{array}$ & & \\
\hline Mercury & All & $7470 \mathrm{~A} / 7471 \mathrm{~A}$ & $\begin{array}{l}<\text { Preliminary } \\
\text { Action Levels }\end{array}$ & & \\
\hline TCLP Mercury & Leachate & 1311/7470A & $\begin{array}{l}\leq \text { Regulatory } \\
\text { Limits }\end{array}$ & & \\
\hline
\end{tabular}

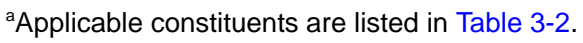

${ }^{\mathrm{b}}$ Test Methods for Evaluating Solid Waste, Physical/Chemical Methods (SW-846) (EPA, 1996)

${ }^{\mathrm{c}}$ The MDC is the lowest concentration that can be reliably achieved within specified limits of accuracy and precision. ${ }^{\mathrm{d}} \mathrm{RPD}$ and \%R performance criteria are developed by the analytical laboratory according to approved procedures.

'Sampling and Analysis Plan (Field Sampling Plan and Quality Assurance Project Plan) with Guidance (EPA, 2002)

'USEPA Contract Laboratory Program National Functional Guidelines for Inorganic Data Review (EPA, 2004a)

RCRA = Resource Conservation and Recovery Act

$\mathrm{RL}=$ Reporting limit

$\mathrm{RPD}=$ Relative percent difference

TCLP = Toxicity Characteristic Leaching Procedure

$\% \mathrm{R}=$ Percent recovery 


\subsection{Results of the DQO Analysis}

The following sections define the results of the DQO process.

\subsubsection{Action Level Determination and Basis}

The PALs presented in this section are to be used for site screening purposes. They are not necessarily intended to be used as cleanup action levels or FALs. However, they are useful in screening out contaminants that are not present in sufficient concentrations to warrant further evaluation, therefore streamlining the consideration of remedial alternatives. The risk-based corrective action (RBCA) process used to establish FALs is described in the Industrial Sites Project Establishment of Final Action Levels (NNSA/NSO, 2006a). This process conforms with Nevada Administrative Code (NAC) Section 445A.227, which lists the requirements for sites with soil contamination (NAC, 2006b). For the evaluation of corrective actions, NAC Section 445A.22705 (NAC, 2006c) recommends the use of American Society for Testing and Materials (ASTM) Method E 1739-95 (ASTM, 1995) to "conduct an evaluation of the site, based on the risk it poses to public health and the environment, to determine the necessary remediation standards (i.e., FALs) or to establish that corrective action is not necessary."

This RBCA process, summarized in Figure 3-1, defines three tiers (or levels) of evaluation involving increasingly sophisticated analyses:

- Tier 1 evaluation - sample results from source areas (highest concentrations) are compared to action levels based on generic (non-site-specific) conditions (i.e., the PALs established in the SAFER). The FALs may then be established as the Tier 1 action levels, or the FALs may be calculated using a Tier 2 evaluation.

- Tier 2 evaluation - conducted by calculating Tier 2 Site-Specific Target Levels (SSTLs) using site-specific information as inputs to the same or similar methodology used to calculate Tier 1 action levels. The Tier 2 SSTLs are then compared to individual sample results from reasonable points of exposure (as opposed to the source areas as is done in Tier 1) on a point-by-point basis. Total TPH concentrations will not be used for risk-based decisions under Tier 2 or Tier 3. Rather, the individual chemicals of concern will be compared to the SSTLS.

- Tier 3 evaluation - conducted by calculating Tier 3 SSTLs on the basis of more sophisticated risk analyses using methodologies described in Method E 1739-95 that consider site-, pathway-, and receptor-specific parameters. 


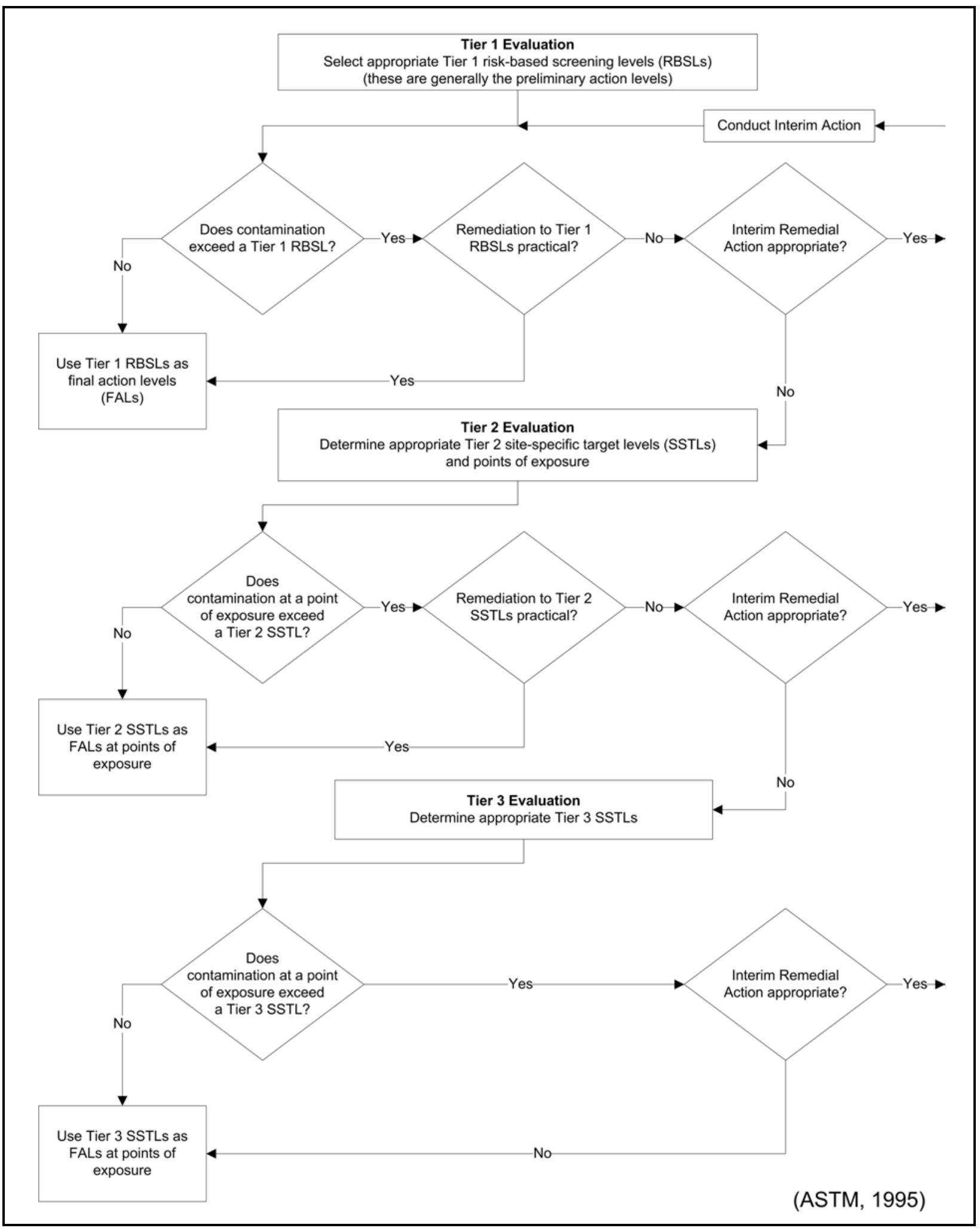

Figure 3-1

Risk-Based Corrective Action Decision Process 
Evaluation of DQO decisions will be based on conditions at the site following completion of any corrective actions. Any corrective actions conducted will be reported in the CR.

The FALs (along with the basis for their selection) will be defined in the CR, where they will be compared to laboratory results in the evaluation of site closure.

\subsubsection{Chemical PALs}

Except as noted herein, the chemical PALs are defined as the U.S. Environmental Protection Agency (EPA) Region 9 Risk-Based Preliminary Remediation Goals (PRGs) for chemical contaminants in industrial soils (EPA, 2004b). Background concentrations for RCRA metals will be used instead of PRGs when natural background concentrations exceed the PRG, as is often the case with arsenic on the NTS. Background is considered the mean plus two standard deviations of the mean for sediment samples collected by the Nevada Bureau of Mines and Geology throughout the Nevada Test and Training Range (formerly the Nellis Air Force Range) (NBMG, 1998; Moore, 1999). For detected chemical COPCs without established PRGs, the protocol used by the EPA Region 9 in establishing PRGs (or similar) will be used to establish PALs. If used, this process will be documented in the CR.

\subsubsection{Total Petroleum Hydrocarbon PALs}

The PAL for TPH is $100 \mathrm{mg} / \mathrm{kg}$ as listed in NAC 445A.2272 (NAC, 2006d).

\subsubsection{Radionuclide PALs}

The PALs for radiological contaminants are based on the National Council on Radiation Protection and Measurement (NCRP) Report No. 129 recommended screening limits for construction, commercial, industrial land-use scenarios (NCRP, 1999) using a 25-millirem-per-year (mrem/yr) dose constraint (Murphy, 2004) and the generic guidelines for residual concentration of radionuclides in DOE Order 5400.5 (DOE, 1993). These PALs are based on the construction, commercial, and industrial land-use scenario provided in the guidance and are appropriate for the NTS based on future land uses presented in Section B.2.2.6. 


\subsubsection{Hypothesis Test}

The baseline condition (i.e., null hypothesis) and alternative condition are:

- Baseline condition - closure objectives have not been met

- Alternative condition - closure objectives have been met

Sufficient evidence to reject the null hypothesis is:

- The identification of the lateral and vertical extent of COC contamination in media, if present.

- Sufficient information to properly dispose of investigation-derived waste (IDW) and remediation waste.

\subsubsection{Statistical Model}

A judgmental sampling design will be implemented to select sample locations and evaluate DQO decisions for CAU 130 CASs. The sampling designs will assume that the data are not normally distributed and that the statistical test will be to compare results to fixed threshold values (i.e., FALs).

\subsubsection{Design Description/Option}

The judgmental sampling approach will be used to collect samples from locations most likely to contain COCs, if present, within each CAS.

All sample locations will be selected to satisfy the DQI of representativeness in that samples collected from selected locations will best represent the populations of interest as defined in Section B.5.1. To meet this criterion for judgmentally sampled sites, a biased sampling strategy will be used for Decision I samples to target areas with the highest potential for contamination, if it is present anywhere in the CAS. Sample locations will be determined based on process knowledge, previously acquired data, or the field-screening and biasing factors listed in Section B.4.2.1. If biasing factors are present in soils below locations where Decision I samples were removed, additional Decision I soil samples will be collected at depth intervals selected by the Site Supervisor based on biasing factors to a depth where the biasing factors are no longer present. The Site Supervisor has the discretion to modify the judgmental sample locations, but only if the modified locations meet the decision needs and criteria stipulated in the DQOs. 
For sampling sites where no biasing criteria are present, random sample locations may be chosen using the Visual Sample Plan (VSP) software (PNNL, 2005). If a sample cannot be collected from a predetermined location for any reason (e.g., rock, caliche, or buried concrete), the Site Supervisor will establish an alternate location at the nearest location where a sample can be obtained.

Because individual sample results rather than an average concentration will be used to compare to FALs at the CASs undergoing judgmental sampling, statistical methods to generate site characteristics will not be used. Adequate representativeness of the entire target population may not be a requirement to developing a sampling design. If good prior information is available on the target site of interest, then the sampling may be designed to collect samples only from areas known to have the highest concentration levels on the target site. If the observed concentrations from these samples are below the action level, then a decision can be made that the site contains safe levels of the contaminant without the samples being truly representative of the entire area (EPA, 2006).

\subsubsection{Conceptual Site Model and Drawing}

The CSM describes the most probable scenario for current conditions at each site and defines the assumptions that are the basis for identifying the future land use, contaminant sources, release mechanisms, migration pathways, exposure points, and exposure routes. The CSM is also used to support appropriate sampling strategies and data collection methods. The CSM has been developed for CAU 130 using information from the physical setting, potential contaminant sources, release information, historical background information, knowledge from similar sites, and physical and chemical properties of the potentially affected media and COPCs. Figure 3-2 depicts a tabular representation of the conceptual pathways to receptors from CAU 130 sources. Figure 3-3 depicts a graphical representation of the CSM. If evidence of contamination that is not consistent with the presented CSM is identified during investigation activities, the situation will be reviewed, the CSM will be revised, the DQOs will be reassessed, and a recommendation will be made as to how best to proceed. In such cases, participants in the DQO process will be notified and given the opportunity to comment on and/or concur with the recommendation. A detailed discussion of the CSM is presented in Appendix B. 


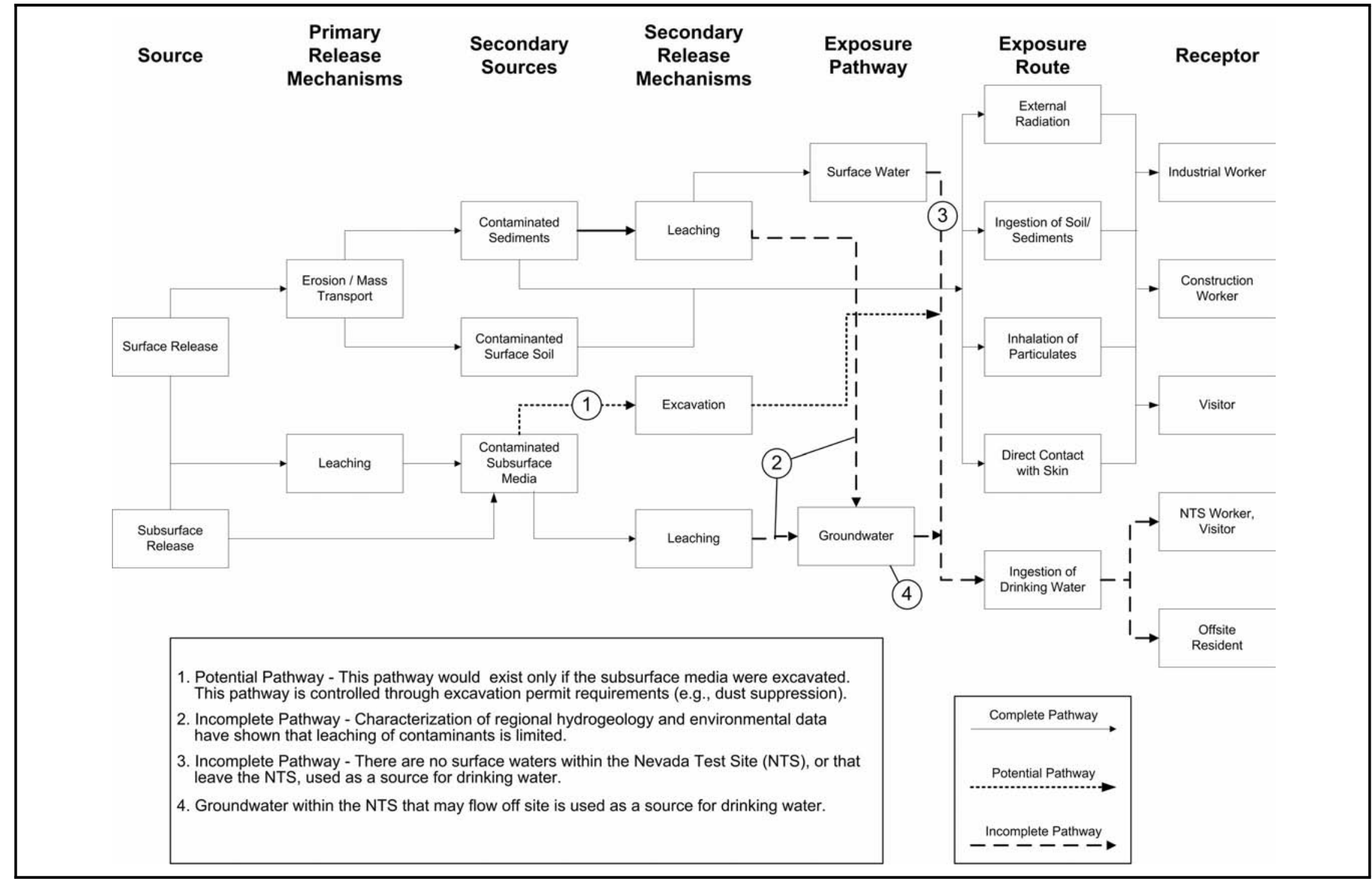

Figure 3-2

Conceptual Site Model Diagram for CAU 130 
H:1130ISAFERI130saferCSM_L.ai

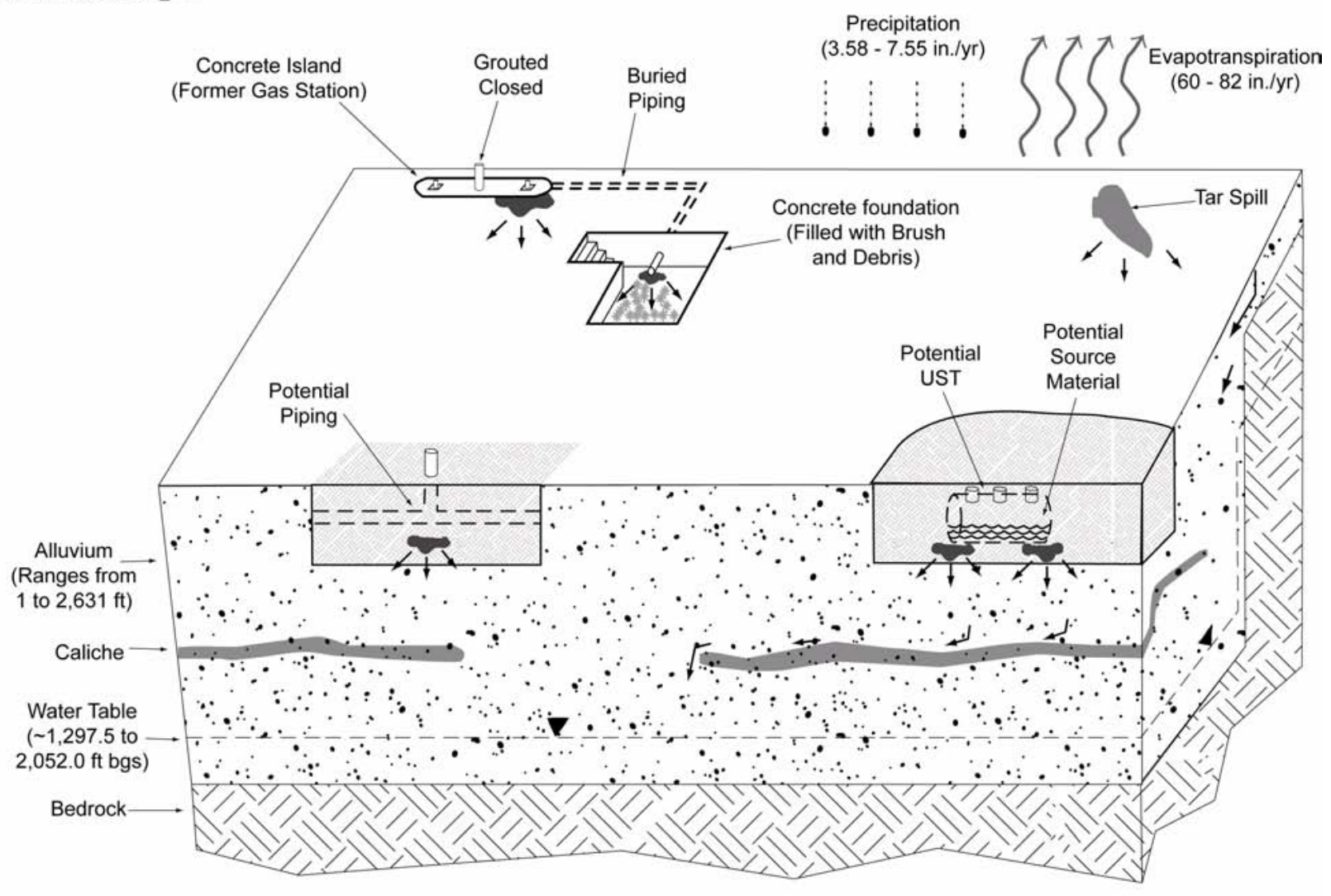

\section{Explanation \\ $\rightarrow$ Subsurface Transport \\ $\Longrightarrow$ Surface Transport \\ Potential Plume \\ Disturbed Soil \\ Buried Debris \\ Not to Scale}

Figure 3-3

Corrective Action Unit 130 Conceptual Site Model 


\subsection{Field Activities and Closure Objectives}

This section of the SAFER Plan provides a description of the field activities and closure objectives for CAU 130. The objectives for the field activities are to determine whether COCs exist. If remediation is determined to be feasible, then the extent of COCs will be determined so that a closure alternative may be implemented. All sampling activities will be conducted in compliance with the Industrial Sites QAPP (NNSA/NV, 2002a) and other applicable, approved procedures and instructions.

\subsection{Contaminants of Potential Concern}

The COPCs for CAU 130 are defined as the list of constituents represented by the analytical methods identified in Table 3-1 for Decision I environmental samples taken at each of the CASs. The constituents reported for each analytical method are listed in Table 3-2.

The list of COPCs is intended to encompass all of the contaminants that could potentially be present at each CAS. These COPCs were identified during the planning process through the review of site history, process knowledge, personal interviews, past investigation efforts (where available), and inferred activities associated with the CASs. Contaminants detected at other similar or other NTS sites were also included in the COPC list to reduce the uncertainty about potential contamination at the CASs because complete information regarding activities performed at the CAU 130 sites is not available.

During the review of site history documentation, process knowledge information, personal interviews, past investigation efforts (where available), and inferred activities associated with the CASs, some of the COPCs were identified as targeted contaminants at specific CASs as discussed in Section 3.1. Targeted contaminants are those COPCs for which evidence in the available site and process information suggests that they may be reasonably suspected to be present at a given CAS. The targeted contaminants are required to meet a more stringent completeness criteria than other COPCs, thus providing greater protection against a decision error. Targeted contaminants for each CAU 130 CAS are identified in Table 3-3. 


\subsection{Remediation}

The DQOs developed for CAU 130 identified data gaps that require additional data collection before identifying and implementing the preferred closure alternative for each CAS. A decision point approach, based on the DQOs, for making remediation decisions is summarized in Figure 1-2. The presence of contamination, if any, is assumed to be confined to the spatial boundaries of the sites as defined in the DQO process and CSM.

If COCs are identified within a CAS based on the initial investigation results, that CAS will be further assessed before implementing closure activities. If COPCs are not present at concentrations exceeding FALs, the CAS will be recommended for no further action. The objective of the initial investigation strategy is to determine whether COCs are present. Laboratory analytical results will be used to confirm the presence or absence of COCs.

If COCs are present, or it is decided that COCs may be present based on the presence of biasing factors, a corrective action of removal for disposal may be implemented and additional verification samples taken from biased locations within the excavation.

The judgmental sampling strategies for the CASs within CAU 130 are presented in Appendix B. Predetermined biased sample locations may be justified by the Site Supervisor, based on the criteria for satisfying DQO data needs listed in Appendix B. Additional samples may be collected for waste management characterization and disposal purposes.

\subsection{Verification}

The information necessary to satisfy the closure criteria will be generated for each CAU 130 CAS by collecting and analyzing samples collected during a field investigation. If a COC is present and removal of the COC is feasible, verification sampling of remaining environmental media will be required. The verification samples will be collected from the approximate center of the bottom of the excavation below the stained area and at lateral boundaries. The final locations and numbers of verification samples to be collected will be determined in the field based on the presence of any biasing factors as listed in Section B.4.2.1 of Appendix B, the size of the excavation, site conditions, and the professional judgment of the Site Supervisor. All verification sample locations must meet the 
DQO decision needs and criteria stipulated in Appendix B. The number and location of verification samples will be justified in the CR.

If a COC is present and removal of the COC is not feasible, information on the extent of COC contamination will be obtained by collecting step-out (Decision II) samples. Decision II sampling will consist of further defining the extent of contamination where COCs have been confirmed. Step-out (Decision II) sampling locations at each CAS will be selected based on the CSM, biasing factors, field-screening results (FSRs), existing data, and the outer boundary sample locations where COCs were detected. In general, step-out sample locations will be arranged in a triangular pattern around areas containing a COC at distances based on site conditions, COC concentrations, process knowledge, and other biasing factors. If COCs extend beyond step-out locations, additional Decision II samples will be collected from locations further from the source. If a spatial boundary is reached, the CSM is shown to be inadequate, or the Site Supervisor determines that extent sampling needs to be re-evaluated, work will be temporarily suspended, NDEP will be notified, and the investigation strategy will be re-evaluated.

The closure objectives will have been met and the CAS, will be proposed for closure if the following conditions are true:

- A COC is not present at a CAS, or a COC is present and the extent of each COC has been defined.

- Information is sufficient to characterize remediation waste and IDW for disposal.

Because this SAFER Plan only addresses contamination originating from the CAU, it may be necessary to distinguish overlapping contamination originating from other sources. For example, widespread surface radiological contamination originating from atmospheric tests will not be addressed in the CAU 130 investigation. To determine whether contamination is from the CAU or from other sources, soil samples may be collected from background locations at selected CASs.

Modifications to the investigation strategy may be required should unexpected field conditions be encountered at any CAS. Significant modifications shall be justified and documented in a Record of Technical Change before implementation. If an unexpected condition indicates that conditions are significantly different than the corresponding CSM, the activity will be rescoped and the decision 
makers will be notified. Field activities at CAU 130 include site preparation, sample location selection, sample collection activities, waste characterization, photodocumentation, and collection of geo-coordinates.

Table 4-1 summarizes the sampling approach to achieve closure objectives for each of the CASs in CAU 130.

Table 4-1

Sampling Approach for CAU 130 Corrective Action Sites (Page 1 of 3)

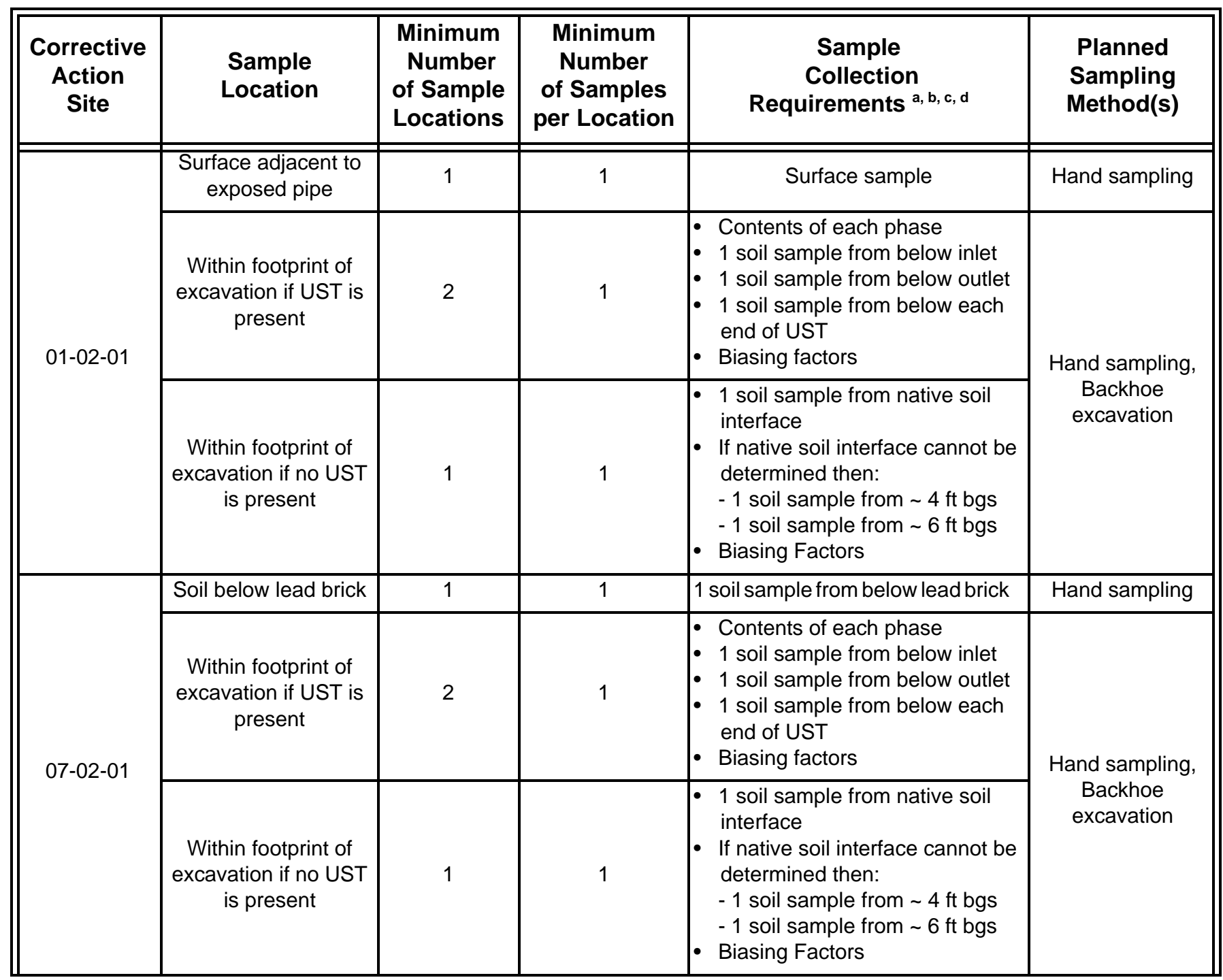


Table 4-1

Sampling Approach for CAU 130 Corrective Action Sites

(Page 2 of 3)

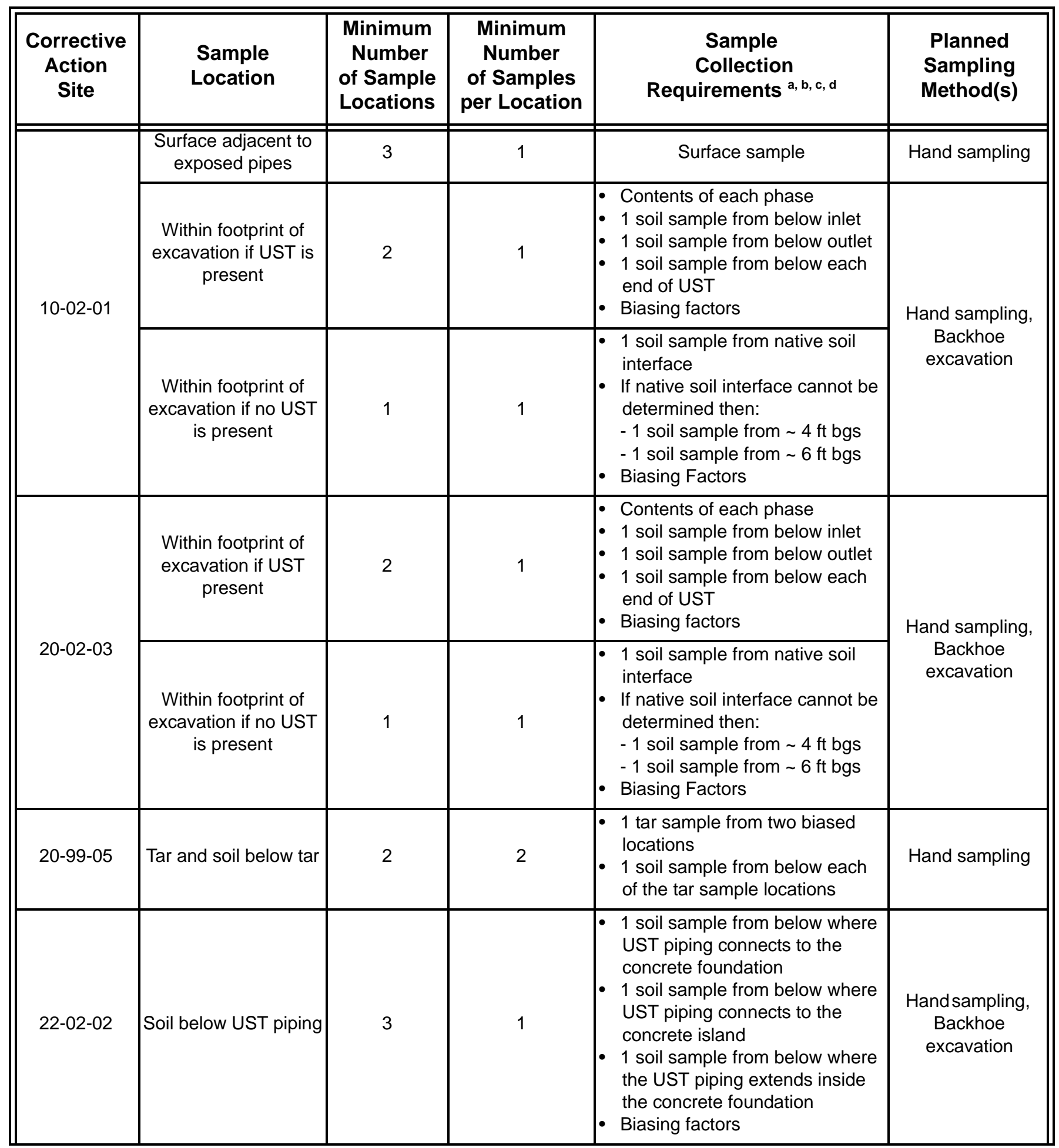


Table 4-1

Sampling Approach for CAU 130 Corrective Action Sites

(Page 3 of 3)

\begin{tabular}{|c|c|c|c|c|c|}
\hline $\begin{array}{l}\text { Corrective } \\
\text { Action } \\
\text { Site }\end{array}$ & $\begin{array}{l}\text { Sample } \\
\text { Location }\end{array}$ & $\begin{array}{l}\text { Minimum } \\
\text { Number } \\
\text { of Sample } \\
\text { Locations }\end{array}$ & $\begin{array}{c}\text { Minimum } \\
\text { Number } \\
\text { of Samples } \\
\text { per Location }\end{array}$ & $\begin{array}{c}\text { Sample } \\
\text { Collection } \\
\text { Requirements }^{a, b, c, d}\end{array}$ & $\begin{array}{l}\text { Planned } \\
\text { Sampling } \\
\text { Method(s) }\end{array}$ \\
\hline \multirow[b]{2}{*}{$23-02-07$} & $\begin{array}{c}\text { Within footprint of } \\
\text { excavation if UST is } \\
\text { present }\end{array}$ & 2 & 1 & $\begin{array}{l}\text { - } \text { Contents of each phase } \\
\text { - } 1 \text { soil sample from below inlet } \\
\text { - } 1 \text { soil sample from below outlet } \\
\text { end of UST } \\
\text { - Biasing factors }\end{array}$ & \multirow{2}{*}{$\begin{array}{c}\text { Hand sampling, } \\
\text { Backhoe } \\
\text { excavation }\end{array}$} \\
\hline & $\begin{array}{l}\text { Within footprint of } \\
\text { excavation if no UST } \\
\text { is present }\end{array}$ & 1 & 1 & $\begin{array}{l}\text { - } 1 \text { soil sample from native soil } \\
\text { interface } \\
\text { - If native soil interface cannot be } \\
\text { determined then: } \\
\text { - } 1 \text { soil sample from } \sim 4 \mathrm{ft} \mathrm{bgs} \\
\text { - } 1 \text { soil sample from } \sim 6 \mathrm{ft} \mathrm{bgs} \\
\text { Biasing Factors }\end{array}$ & \\
\hline
\end{tabular}

${ }^{a}$ For worker protection, field screening will not be conducted if a strong odor and/or visual evidence suggests contamination is present.

${ }^{\mathrm{b}}$ Additional samples may be collected at the discretion of the Site Supervisor.

${ }^{\mathrm{c}}$ Additional samples may be submitted at the discretion of the Site Supervisor.

${ }^{\mathrm{d}}$ Surface sample interval is 0 to 6 in. Shallow subsurface sample interval is $6 \mathrm{in}$. to $5 \mathrm{ft}$. Subsurface sample interval is greater than $5 \mathrm{ft}$.

bgs $=$ Below ground surface

$\mathrm{ft}=$ Foot

UST = Underground storage tank

\subsection{Closure}

The following activities, at a minimum, have been identified for closure of the CAU 130 CASs. The decision logic behind the activities is provided in Figure 1-2:

- If no COCs are detected, the CAS will be closed with no further action.

- If COCs are present and removal of the COCs is not feasible, closure in place will be the preferred corrective action alternative. The appropriate use restrictions will be implemented and documented in the SAFER CR.

- If COCs are present and removal of the COCs is feasible, clean closure will be the preferred corrective action alternative. The material to be remediated will be removed and disposed as waste, and verification samples will be collected in remaining soil. Verification analytical results will be documented in the SAFER CR.

- Identified USTs will be closed is accordance with NAC 459.9972 (NAC, 2007), and contents will be removed. 
- Identified UST contents, if any, will be disposed of in accordance with Section 6.0 of this SAFER Plan.

- Identified lead brick(s) will be disposed of in accordance with Section 6.0 of this SAFER Plan.

Following completion of CAI and waste management activities, the following actions will be implemented before closure of the site Real Estate/Operations Permit:

- Removing all equipment, wastes, debris, and materials associated with the CAI

- Removing all signage and fencing (unless part of a corrective action)

- Grading site to pre-investigation condition (unless changed condition is necessary under a corrective action)

- Inspecting site and certifying that restoration activities have been completed

\subsection{Duration}

Table 4-2 is a tentative duration of activities (in calendar days) for SAFER activities:

Table 4-2

SAFER Field Activities

\begin{tabular}{|c|c|}
\hline Duration (days) & Activity \\
\hline \hline 20 & Site Preparation \\
\hline 3 & Site Mobilization \\
\hline 30 & Field Work \\
\hline 28 & Sample Analysis \\
\hline 42 & Data Validation and Assessment \\
\hline 195 & Closure Report \\
\hline 180 & Waste Management and Disposition \\
\hline
\end{tabular}




\subsection{Reports and Records Availability}

Reports generated during ongoing field activities will be provided to NDEP upon request. Historic information and documents referenced in this plan are retained in the NNSA/NSO project files in Las Vegas, Nevada, and can be obtained through written request to the NNSA/NSO Project Manager. This document is available in the DOE public reading rooms located in Las Vegas and Carson City, Nevada, or by contacting the appropriate DOE project manager. The NDEP maintains the official Administrative Record for all activities conducted under the auspices of the FFACO. 


\subsection{Investigation/Remediation Waste Management}

Management of IDW will be based on regulatory requirements, field observations, process knowledge, and laboratory results from CAU 130 investigation samples.

Disposable sampling equipment, personal protective equipment (PPE), and rinsate are considered potentially contaminated waste only by virtue of contact with potentially contaminated media (e.g., soil) or potentially contaminated debris (e.g., construction materials). Therefore, sampling and analysis of IDW, separate from analyses of site investigation samples, may not be necessary for all IDW. However, if associated investigation samples are found to contain contaminants above regulatory levels, conservative estimates of total waste contaminant concentrations may be made based on the mass of the waste, the amount of contaminated media contained in the waste, and the maximum concentration of contamination found in the media. Direct samples of IDW may also be taken to support waste characterization.

Sanitary, hazardous, radioactive, and/or mixed waste, if generated, will be managed and disposed of in accordance with applicable DOE orders, U.S. Department of Transportation (DOT) regulations, state and federal waste regulations, and agreements and permits between DOE and NDEP.

\subsection{Waste Minimization}

Investigation activities are planned to minimize IDW generation. This will be accomplished by incorporating the use of process knowledge, visual examination, and/or radiological survey and swipe results. When possible, disturbed media (such as soil removed during trenching, or decontamination) or debris will be returned to its original location. Contained media (e.g., soil managed as waste) as well as other IDW will be segregated to the greatest extent possible to minimize generation of hazardous, radioactive, or mixed waste. Hazardous material used at the sites will be controlled in order to limit unnecessary generation of hazardous or mixed waste. Administrative controls, including decontamination procedures, recycle/reuse, and waste characterization strategies, will minimize waste generated during investigations. 


\subsection{Potential Waste Streams}

Waste generated during the corrective action activities may include the following potential waste streams:

- Personal protective equipment and disposable sampling equipment (e.g., plastic, paper, sample containers, aluminum foil, spoons, bowls)

- Decontamination rinsate

- Environmental media (e.g., soil)

- Remediation debris in investigation area (e.g., UST)

- Surface debris in investigation area (e.g., construction debris, scrap, lead brick)

- Field-screening waste (e.g., spent solvent, disposable sampling equipment, and/or PPE contaminated by field-screening activities)

The onsite management and ultimate disposition of wastes will be determined based on a determination of the waste type (e.g., sanitary, low-level, hazardous, hydrocarbon, mixed), or the combination of waste types. A determination of the waste type will be guided by several factors, including, but not limited to: the analytical results of samples either directly or indirectly associated with the waste, historical site knowledge, knowledge of the waste generation process, field observations, field-monitoring results/FSRs, and/or radiological survey/swipe results.

Guidance from the NV/YMP Radiological Control (RadCon) Manual (NNSA/NSO, 2004) shall be used to determine whether such materials may be declared nonradioactive. Onsite IDW management requirements by waste type are detailed in the following sections. Applicable waste management regulations and requirements are listed in Table 6-1. 
Table 6-1

Waste Management Regulations and Requirements

\begin{tabular}{|c|c|c|}
\hline Waste Type & Federal Regulation & Additional Requirements \\
\hline Solid (nonhazardous) & N/A & $\begin{array}{c}\text { NRS }^{\mathrm{a}} 444.440-444.620 \\
\text { NAC }^{\mathrm{b}} 444.570-444.7499 \\
\text { NTS Landfill Permit SW13.097.04 }{ }^{\mathrm{c}}, \text { Rev. } 5 \\
\text { NTS Landfill Permit SW13.097.03 }{ }^{\mathrm{d}} \text {, Rev. } 7\end{array}$ \\
\hline Liquid/Rinsate (nonhazardous) & N/A & $\begin{array}{l}\text { Water Pollution Control General Permit } \\
\text { GNEV93001, Rev. 3iv }\end{array}$ \\
\hline Hazardous & $\begin{array}{c}\text { RCRA }^{f}, \\
40 \text { CFR } 260-282\end{array}$ & $\begin{array}{c}\mathrm{NRS}^{\mathrm{a}} 459.400-459.600 \\
\mathrm{NAC}^{\mathrm{b}} 444.850-444.8746 \\
\text { POC }^{\mathrm{g}}\end{array}$ \\
\hline Low-Level Radioactive & N/A & DOE Orders and NTSWAC ${ }^{h}$ \\
\hline Mixed & $\begin{array}{c}\text { RCRA }^{f} \\
40 \text { CFR 260-282 }\end{array}$ & $\begin{array}{l}\text { NTSWAC } \\
\text { POC }^{\mathrm{h}}\end{array}$ \\
\hline Hydrocarbon & $\mathrm{N} / \mathrm{A}$ & NTS Landfill Permit SW13.097.02i, Rev. 7 \\
\hline Polychlorinated Biphenyls & $\begin{array}{c}\text { TSCA }^{j} \\
40 \text { CFR } 761\end{array}$ & $\begin{array}{l}\text { NRS }^{a} 459.400-459.600 \\
\text { NAC }^{b} 444.940-444.9555\end{array}$ \\
\hline Asbestos & $\begin{array}{c}\text { TSCA }^{\mathrm{j}} \\
40 \text { CFR } 763\end{array}$ & $\begin{array}{l}\text { NRS }^{a} 618.750-618.840 \\
\text { NAC }^{b} 444.965-444.976\end{array}$ \\
\hline
\end{tabular}

${ }^{\mathrm{a} N e v a d a}$ Revised Statutes (NRS, 2007a, b, and c)

${ }^{\mathrm{b}}$ Nevada Administrative Code (NAC, 2006a)

${ }^{\mathrm{c} A r e a} 23$ Class II Solid Waste Disposal Site (NDEP, 2006a)

${ }^{\mathrm{d} A r e a} 9$ Class III Solid Waste Disposal Site (NDEP, 2006c)

${ }^{\mathrm{e}}$ Nevada Test Site Sewage Lagoons (NDEP, 2005)

${ }^{\mathrm{f}}$ Resource Conservation and Recovery Act (CFR, 2007a)

${ }^{9}$ Nevada Test Site Performance Objective for the Certification of Nonradioactive Hazardous Waste (BN, 1995)

${ }^{\mathrm{h}}$ Nevada Test Site Waste Acceptance Criteria, Rev. 6 (NNSA/NSO, 2006b)

iArea 6 Class III Solid Waste Disposal Site for hydrocarbon waste (NDEP, 2006b)

${ }^{\mathrm{j}}$ Toxic Substances Control Act (CFR, 2007b and c)

CFR $=$ Code of Federal Regulations

DOE $=$ U.S. Department of Energy

N/A = Not applicable

NAC $=$ Nevada Administrative Code

NDEP $=$ Nevada Division of Environmental Protection

NRS $=$ Nevada Revised Statutes

NTS = Nevada Test Site

NTSWAC $=$ Nevada Test Site Waste Acceptance Criteria

$\mathrm{POC}=$ Performance Objective for the Certification of Nonradioactive Hazardous Waste

RCRA = Resource Conservation and Recovery Act

TSCA = Toxic Substances Control Act 


\subsubsection{Sanitary Waste}

Sanitary IDW generated at each CAS will be collected, managed, and disposed of in accordance with the sanitary waste management regulations and the permits for operation of the NTS 10c Industrial Waste Landfill (see Table 6-1).

Office trash and lunch waste will be placed in the dumpster to be transported to the sanitary landfill for disposal. Industrial IDW generated at each CAS will be placed in a roll-off box located in Mercury, or other approved roll-off box location for ultimate disposal in the 10c Industrial Waste Landfill.

\subsubsection{Low-Level Radioactive Waste}

Radiological swipe surveys and/or direct-scan surveys may be conducted on reusable sampling equipment and the PPE and disposable sampling equipment waste streams exiting a radiologically controlled area (RCA). This allows for the immediate segregation of radioactive waste from waste that may be unrestricted regarding radiological release. Removable contamination limits, as defined in the current version of the NV/YMP RadCon Manual (NNSA/NSO, 2004), will be used to determine whether such waste may be declared unrestricted regarding radiological release versus being declared radioactive waste. Direct sampling of the waste may be conducted to aid in determining whether a particular waste unit (e.g., drum of soil) contains low-level radioactive waste, as necessary. Waste that is determined to be below the release values, by either direct radiological survey/swipe results or through process knowledge, will not be managed as potential radioactive waste but will be managed in accordance with the appropriate section of this document. Wastes with values/release criteria in excess will be managed as potential radioactive waste, and managed in accordance with this section and any other applicable sections of this document.

Low-level radioactive waste, if generated, will be managed in accordance with the contractor-specific waste certification program plan, DOE orders, and the requirements of the current version of the Nevada Test Site Waste Acceptance Criteria (NTSWAC) (NNSA/NSO, 2006b). Potential radioactive waste drums containing soil, PPE, disposable sampling equipment, and/or rinsate may be staged and managed at a designated radioactive material area (RMA) or RCA when full or at the end of an investigation phase. 


\subsubsection{Hazardous Waste}

The CAU will have waste accumulation areas established according to the needs of the project. Satellite accumulation areas and hazardous waste accumulation areas (HWAAs) will be managed consistent with the requirements of federal and state regulations (see Table 6-1). The HWAAs will be properly controlled for access, and will be equipped with spill kits and appropriate spill containment. Wastes will be placed in DOT-compliant containers. All containerized hazardous waste will be handled, inspected, and managed in accordance with the hazardous waste regulations (see Table 6-1). These provisions include managing the waste in containers compatible with the waste type, and segregating incompatible waste types so that in the event of a spill, leak, or release, incompatible wastes shall not contact one another. The HWAAs will be covered under a site-specific emergency response and contingency action plan until such time that the waste is determined to be nonhazardous or all containers of hazardous waste have been removed from the storage area. Hazardous waste will be characterized, managed, and disposed in accordance with federal requirements. Resource Conservation and Recovery Act-“listed” waste has not been identified at CAU 130.

\subsubsection{Hydrocarbon Waste}

Hydrocarbon soil waste containing more than $100 \mathrm{mg} / \mathrm{kg}$ of TPH will be managed on site in a drum or other appropriate container until fully characterized. Hydrocarbon waste may be disposed of at a designated hydrocarbon landfill, an appropriate hydrocarbon waste management facility (e.g., recycling facility), or other method in accordance with State of Nevada regulations (see Table 6-1).

\subsubsection{Mixed Low-Level Waste}

Mixed waste, if generated, shall be managed and dispositioned according to the requirements of RCRA, or subject to agreements between NNSA/NSO and the State of Nevada, as well as DOE requirements for radioactive waste (see Table 6-1). Mixed waste that does not meet NTSWAC will require development of a treatment and disposal plan under the requirements of the Mutual Consent Agreement between DOE and the State of Nevada (NDEP, 1995). 


\subsubsection{Polychlorinated Biphenyls}

The management of PCBs is governed and implemented by Toxic Substances Control Act (TSCA) regulation (see Table 6-1). Polychlorinated biphenyl contamination may be found as a sole contaminant or in combination with any of the types of waste discussed in this document. For example, PCBs may be a co-contaminant in soil that contains a RCRA "characteristic" waste (PCB/hazardous waste), or in soil that contains radioactive wastes (PCB/radioactive waste), or even in mixed waste (PCB/radioactive/hazardous waste). If regulated PCB waste is generated, it will be managed according to federal and State of Nevada requirements, and agreements with NNSA/NSO.

\subsection{Management of Specific Waste Streams}

\subsubsection{Personal Protective Equipment}

Personal protective equipment and disposable sampling equipment will be visually inspected for stains, discoloration, and gross contamination as the waste is generated, and also evaluated for radiological contamination. Staining and/discoloration will be assumed to be the result of contact with potentially contaminated media such as soil, sludge, or liquid. Gross contamination is the visible contamination of an item (e.g., clumps of soil/sludge on a sampling spoon or free liquid smeared on a glove). While gross contamination can often be removed through decontamination methods, removal of gross contamination from small items, such as gloves or booties is not typically conducted. Any IDW grossly contaminated will be segregated and managed as potentially "characteristic" hazardous waste. This segregated population of waste will either: (1) be assigned the characterization of the soil/sludge that was sampled, (2) be sampled directly, or (3) undergo further evaluation using associated soil/sludge sample results to determine how much soil/sludge would need to be present in the waste to exceed regulatory levels. Waste that is determined to be hazardous will be entered into an approved waste management system, where it will be managed and dispositioned according to RCRA requirements or subject to agreements between NNSA/NSO and the State of Nevada (see Table 6-1). The PPE and equipment that is not visibly stained, discolored, or grossly contaminated and that is within the radiological free-release criteria will be managed as nonhazardous sanitary waste. 


\subsubsection{Management of Decontamination Rinsate}

Rinsate waste may be generated from the decontamination of field sampling equipment and may be managed as RCRA-hazardous or non-hazardous waste, depending on process knowledge and associated analytical data. Depending on the radiological characterization of the rinsate waste, non-hazardous rinsate may be managed for disposal at the point of generation in accordance with an NNSA/NSO approved Fluid Management Plan, or disposed elsewhere in accordance with the receiving facility's waste acceptance criteria. Hazardous and/or radioactive rinsate wastes will be managed and disposed in accordance with federal and state regulations, and the waste acceptance criteria of the appropriate waste disposal facility.

Wet or dry decontamination may be performed over the sampling site. In such cases, decontamination rinsate waste may be generated. If it is generated, it will be containerized, characterized and managed as noted above. When onsite equipment decontamination is performed, it will be done in such a manner as to introduce no new contaminants to the sampling site or to cause existing contaminants to migrate from the site.

\subsubsection{Management of Soil}

This waste stream consists of soil removed for disposal during soil sampling, excavation, and/or drilling. This waste stream will be characterized based on laboratory analytical results from representative locations. If the soil is determined to potentially contain COCs, the material will either be managed on site or containerized for transportation to an appropriate disposal site.

Onsite management of the waste soil will be allowed only if it is managed within an area of concern and it is appropriate to defer the management of the waste until the final remediation of the site. If this option is chosen, the waste soil shall be protected from run-on and runoff using appropriate protective measures based on the type of contaminant(s) (e.g., covered with plastic and bermed).

Management of soil waste for disposal consists of placing the waste in containers, labeling the containers, temporarily storing the containers until shipped, and shipping the waste to a disposal site. The containers, labels, management of stored waste, transport to the disposal site, and disposal shall be appropriate for the type of waste (e.g., hazardous, hydrocarbon, mixed). 
Note that soil placed back into an excavation in the same approximate location from which it originated is not considered to be a waste.

\subsubsection{Management of Debris}

This waste stream can vary depending on site conditions. Debris that requires removal must be characterized for proper management and disposition. Historical site knowledge, knowledge of the waste generation process, field observations, field-monitoring results/FSRs, radiological survey/swipe results and/or the analytical results of samples either directly or indirectly associated with the waste may be used to characterized the debris. Debris will be visually inspected for stains, discoloration, and gross contamination. Debris may be deemed reusable, recyclable, sanitary waste, hazardous waste, PCB waste, or low-level waste. Waste that is not sanitary will be entered into an approved waste management system, where it will be managed and dispositioned according to federal, state requirements, and agreements between NNSA/NSO and the State of Nevada (see Table 6-1). Debris may be managed on site by berming and covering next to the excavation, by placing in a container(s), or by being left on the footprint of the CAS and its disposition deferred until implementation of corrective action at the site.

\subsubsection{Field-Screening Waste}

The use of field test kits and/or instruments may result in the generation of small quantities of hazardous wastes. If hazardous waste is produced by field screening, it will be segregated from other IDW and managed in accordance with the hazardous waste regulations. For sites where field-screening samples contain radioactivity above background levels, field-screening methods that have the potential to generate hazardous waste will not be used, thus avoiding the potential to generate mixed waste. In the event a mixed waste is generated, the waste will be managed in accordance with Section 6.2.5 of this document. 


\subsection{Quality Assurance/Quality Control}

The overall objective of the characterization activities described in this SAFER Plan is to collect accurate and defensible data to support the selection and implementation of a closure alternative for each CAS in CAU 130. Sections 7.1 and 7.2 discuss the collection of required quality control (QC) samples in the field and quality assurance (QA) requirements for laboratory/analytical data to achieve closure. Unless otherwise stated in this SAFER Plan or required by the results of the DQO process (see Appendix B), this investigation will adhere to the Industrial Sites QAPP (NNSA/NV, 2002a).

\subsection{Sample Collection Activities}

Field QC samples will be collected in accordance with established procedures. Field QC samples are collected and analyzed to aid in determining the validity of environmental sample results. The number of required QC samples depends on the types and number of environmental samples collected. The minimum frequency of collecting and analyzing QC samples for this investigation, as determined in the DQO process, include:

- $\quad$ Trip blanks (1 per sample cooler containing VOC environmental samples)

- Equipment rinsate blanks (1 per sampling event for each type of decontamination procedure)

- $\quad$ Source blanks (1 per uncharacterized lot of source material that contacts sampled media)

- Field duplicates (1 per 20 environmental samples or 1 per CAS per matrix, if less than 20 collected)

- $\quad$ Field blanks (1 per CAS)

- Laboratory QC samples (1 per 20 environmental samples or 1 per CAS per matrix, if less than 20 collected)

Additional QC samples may be submitted based on site conditions at the discretion of the Task Manager or Site Supervisor. Field QC samples shall be analyzed using the same analytical procedures implemented for associated environmental samples. Additional details regarding field QC samples are available in the Industrial Sites QAPP (NNSA/NV, 2002a). 


\subsection{Applicable Laboratory/Analytical Data Quality Indicators}

The DQIs are qualitative and quantitative descriptors used in interpreting the degree of acceptability or utility of data. Data quality indicators are used to evaluate the entire measurement system and laboratory measurement processes (i.e., analytical method performance) as well as to evaluate individual analytical results (i.e., parameter performance). The quality and usability of data used to make DQO decisions will be assessed based on the following DQIs:

- Precision

- Accuracy/bias

- Representativeness

- Comparability

- Completeness

- Sensitivity

Table 7-1 provides the established analytical method/measurement system performance criteria for each of the DQIs and the potential impacts to the decision if the criteria are not met. The following subsections discuss each of the DQIs that will be used to assess the quality of laboratory data. Due to changes in analytical methodology and changes in analytical laboratory contracts, criteria for precision and accuracy in Tables 3-4 and 3-5 that vary from corresponding information in the QAPP will supersede that information in the QAPP (NNSA/NV, 2002a).

Table 7-1

Laboratory and Analytical Performance Criteria for CAU 130 Data Quality Indicators (Page 1 of 2)

\begin{tabular}{|c|c|c|}
\hline $\begin{array}{l}\text { Data Quality } \\
\text { Indicator }\end{array}$ & Performance Metric & $\begin{array}{l}\text { Potential Impact on Decision } \\
\text { If Performance Metric Not Met }\end{array}$ \\
\hline Precision & $\begin{array}{l}\text { At least } 80 \% \text { of the sample results for each } \\
\text { measured contaminant are not qualified for } \\
\text { precision based on the criteria for each analytical } \\
\text { method-specific and laboratory-specific criteria } \\
\text { presented in Tables 3-4 and 3-5. }\end{array}$ & $\begin{array}{l}\text { If the performance metric is not met, the } \\
\text { affected analytical results from each affected } \\
\text { CAS will be assessed to determine whether } \\
\text { there is sufficient confidence in analytical } \\
\text { results to use the data in making DQO } \\
\text { decisions. }\end{array}$ \\
\hline Accuracy & $\begin{array}{l}\text { At least } 80 \% \text { of the sample results for each } \\
\text { measured contaminant are not qualified for } \\
\text { accuracy based on the method-specific and } \\
\text { laboratory-specific criteria presented in } \\
\text { Tables 3-4 and 3-5. }\end{array}$ & $\begin{array}{l}\text { If the performance metric is not met, the } \\
\text { affected analytical results from each affected } \\
\text { CAS will be assessed to determine whether } \\
\text { there is sufficient confidence in analytical } \\
\text { results to use the data in making DQO } \\
\text { decisions. }\end{array}$ \\
\hline Representativeness & $\begin{array}{l}\text { Samples contain contaminants at concentrations } \\
\text { present in the environmental media from which } \\
\text { they were collected. }\end{array}$ & $\begin{array}{c}\text { Analytical results will not represent true site } \\
\text { conditions. Inability to make appropriate } \\
\text { DQO decisions. }\end{array}$ \\
\hline
\end{tabular}


Table 7-1

Laboratory and Analytical Performance Criteria for CAU 130 Data Quality Indicators (Page 2 of 2)

\begin{tabular}{||c|c|c|}
\hline $\begin{array}{c}\text { Data Quality } \\
\text { Indicator }\end{array}$ & Performance Metric & $\begin{array}{c}\text { Potential Impact on Decision } \\
\text { If Performance Metric Not Met }\end{array}$ \\
\hline \hline Comparability & $\begin{array}{c}\text { Sampling, handling, preparation, analysis, } \\
\text { reporting, and data validation are performed } \\
\text { using standard methods and procedures. }\end{array}$ & $\begin{array}{c}\text { Inability to combine data with data obtained } \\
\text { from other sources and/or inability to } \\
\text { compare data to regulatory action levels. }\end{array}$ \\
\hline Completeness & $\begin{array}{c}80 \% \text { of the CAS-specific COPCs have valid } \\
\text { results. }\end{array}$ & $\begin{array}{c}\text { Cannot support/defend decision on whether } \\
\text { COCs are present. }\end{array}$ \\
\hline Sensitivity & $\begin{array}{c}\text { Minimum detectable concentrations are less than } \\
\text { or equal to respective FALs. }\end{array}$ & $\begin{array}{c}\text { Cannot determine whether COCs are } \\
\text { present or migrating at levels of concern. }\end{array}$ \\
\hline Extent Completeness & $\begin{array}{c}100 \% \text { of COCs used to define extent have valid } \\
\text { results. }\end{array}$ & $\begin{array}{c}\text { Extent of contamination cannot be } \\
\text { accurately determined. }\end{array}$ \\
\hline $\begin{array}{c}\text { Clean Closure } \\
\text { Completeness }\end{array}$ & $\begin{array}{c}100 \% \text { of targeted contaminants have valid } \\
\text { results. }\end{array}$ & $\begin{array}{c}\text { Cannot determine whether COCs remain in } \\
\text { soil. }\end{array}$ \\
\hline
\end{tabular}

CAS $=$ Corrective Action Site

$\mathrm{COC}=$ Contaminant of concern

$\mathrm{COPC}=$ Contaminant of potential concern

$\mathrm{DQO}=$ Data quality objective
FAL $=$ Final action level

ND $=$ Normalized difference

$\mathrm{RPD}=$ Relative percent difference

\subsubsection{Precision}

Precision is a measure of the repeatability of the analysis process from sample collection through analysis results. It is used to assess the variability between two equal samples.

Determinations of precision will be made for field duplicate samples and laboratory duplicate samples. Field duplicate samples will be collected simultaneously with samples from the same source under similar conditions in separate containers. The duplicate sample will be treated independently of the original sample in order to assess field impacts and laboratory performance on precision through a comparison of results. Laboratory precision is evaluated as part of the required laboratory internal QC program to assess performance of analytical procedures. The laboratory sample duplicates are an aliquot, or subset, of a field sample generated in the laboratory. They are not a separate sample but a split, or portion, of an existing sample. Typically, laboratory duplicate QC samples may include matrix spike duplicate (MSD) and laboratory control sample (LCS) duplicate samples for organic, inorganic, and radiological analyses. 
Precision is a quantitative measure used to assess overall analytical method and field-sampling performance as well as to assess the need to "flag” (qualify) individual parameter results when corresponding QC sample results are not within established control limits.

The criteria used for the assessment of inorganic chemical precision when both results are greater than or equal to $5 \mathrm{x}$ reporting limit (RL) is 20 percent and 35 percent for aqueous and soil samples, respectively. When either result is less than $5 x \mathrm{RL}$, a control limit of $\pm 1 x \mathrm{RL}$ and $\pm 2 \mathrm{x}$ RL for aqueous and soil samples, respectively, is applied to the absolute difference.

The criteria used for the assessment of organic chemical precision is based on professional judgment using laboratory derived control limits.

The criteria used for the assessment of radiological precision when both results are greater than or equal to 5x MDC is 20 percent and 35 percent for aqueous and soil samples, respectively. When either result is less than 5x MDC, the normalized difference (ND) should be between -2 and +2 for aqueous and soil samples. The parameters to be used for assessment of precision for duplicates are listed in Table 3-5.

Any values outside the specified criteria do not necessarily result in the qualification of analytical data. It is only one factor in making an overall judgment about the quality of the reported analytical results. The performance metric for assessing the DQI of precision on DQO decisions (see Table 7-1) is that at least 80 percent of sample results for each measured contaminant are not qualified due to duplicates exceeding the criteria. If this performance is not met, an assessment will be conducted in the CR on the impacts to DQO decisions specific to affected contaminants and CASs.

\subsubsection{Accuracy}

Accuracy is a measure of the closeness of an individual measurement to the true value. It is used to assess the performance of laboratory measurement processes.

Accuracy is determined by analyzing a reference material of known parameter concentration or by reanalyzing a sample to which a material of known concentration or amount of parameter has been added (spiked). Accuracy will be evaluated based on results from three types of spiked samples: matrix spike (MS), LCS, and surrogates (organics). The LCS sample is analyzed with the field 
samples using the same sample preparation, reagents, and analytical methods employed for the samples. One LCS will be prepared with each batch of samples for analysis by a specific measurement.

The criteria used for the assessment of inorganic chemical accuracy are 75 to 125 percent for MS recoveries and 80 to 120 percent for LCS recoveries. For organic chemical accuracy, MS and LCS laboratory-specific percent recovery criteria developed and generated in-house by the laboratory according to approved laboratory procedures are applied. The criteria used for the assessment of radiochemical accuracy are 80 to 120 percent for LCS and MS recoveries.

Any values outside the specified criteria do not necessarily result in the qualification of analytical data. It is only one factor in making an overall judgment about the quality of the reported analytical results. Factors beyond laboratory control, such as sample matrix effects, can cause the measured values to be outside of the established criteria. Therefore, the entire sampling and analytical process may be evaluated when determining the usability of the affected data.

The performance metric for assessing the DQI of accuracy on DQO decisions (see Table 7-1) is that at least 80 percent of the sample results for each measured contaminant are not qualified for accuracy. If this performance is not met, an assessment will be conducted in the CR on the impacts to DQO decisions specific to affected contaminants and CASs.

\subsubsection{Representativeness}

Representativeness is the degree to which sample characteristics accurately and precisely represent a characteristics of a population or an environmental condition (EPA, 2002). Representativeness is assured by a carefully developing the sampling strategy during the DQO process such that false negative and false positive decision errors are minimized. The criteria listed in DQO Step 6 - Specify the Tolerable Limits on Decision Errors are:

- For Decision I judgmental sampling, having a high degree of confidence that the sample locations selected will identify COCs if present anywhere within the CAS. 
- For Decision II, having a high degree of confidence that analyses conducted will be sufficient to detect any COCs present in the samples.

- For Decision II, having a high degree of confidence that the sample locations selected will identify the extent of COCs.

These are qualitative measures that will be used to assess measurement system performance for representativeness. The assessment of this qualitative criterion will be presented in the CR.

\subsubsection{Comparability}

Comparability is a qualitative parameter expressing the confidence with which one dataset can be compared to another (EPA, 2002). The criteria for the evaluation of comparability will be that all sampling, handling, preparation, analysis, reporting, and data validation were performed using approved standard methods and procedures. This will ensure that data from this project can be compared to regulatory action levels that were developed based on data generated using the same or comparable methods and procedures. An evaluation of comparability will be presented in the CR.

\subsubsection{Completeness}

Completeness is defined as generating sufficient data of the appropriate quality to satisfy the data needs identified in the DQOs. For judgmental sampling, completeness will be evaluated using both a quantitative measure and a qualitative assessment. The quantitative measurement to be used to evaluate completeness is presented in Table 7-1 and is based on the percentage of measurements made that are judged to be valid. For the judgmental sampling approach, the completeness goal for targeted contaminants and the remaining COPCs is 100 and 80 percent, respectively. If this goal is not achieved, the dataset will be assessed for potential impacts on making DQO decisions.

The qualitative assessment of completeness is an evaluation of the sufficiency of information available to make DQO decisions. This assessment will be based on meeting the data needs identified in the DQOs and will be presented in the CR. Additional samples will be collected if it is determined that the number of samples do not meet completeness criteria. 


\subsubsection{Sensitivity}

Sensitivity is the capability of a method or instrument to discriminate between measurement responses representing different levels of the variable of interest (EPA, 2002). The evaluation criteria for this parameter will be that measurement sensitivity (detection limits) will be less than or equal to the corresponding FALs. If this criterion is not achieved, the affected data will be assessed for usability and potential impacts on meeting site characterization objectives. This assessment will be presented in the CR. 


\subsection{References}

ASTM, see American Society for Testing and Materials.

American Society for Testing and Materials. 1995. Standard Guide for Risk-Based Corrective Action Applied at Petroleum Release Sites, ASTM E 1739-95 (Reapproved 2002). Philadelphia, PA.

Author Unknown. 1994. “Expended Gas Sample Tank - Disposal Checklist,” 16 August.

Las Vegas, NV.

BN, see Bechtel Nevada.

Bechtel Nevada. 1995. Nevada Test Site Performance Objective for Certification of Nonradioactive Hazardous Waste, Rev. 0, G-E11/96.01. Las Vegas, NV.

Bechtel Nevada. 1999. An Aerial Radiological Survey of the Nevada Test Site, DOE/NV/11718--324. Prepared for the U.S. Department of Energy, Nevada Operations Office. Nellis Air Force Base, NV: Remote Sensing Laboratory.

CFR, see Code of Federal Regulations.

Code of Federal Regulations. 2007a. Title 40 CFR, Parts 260-282, "Hazardous Waste Management System: General.” Washington, DC: U.S. Government Printing Office.

Code of Federal Regulations. 2007b. Title 40 CFR, Parts 761, "Polychlorinated Biphenyls (PCBs) Manufacturing, Processing, Distribution in Commerce, and Use Prohibitions.” Washington, DC: U.S. Government Printing Office.

Code of Federal Regulations. 2007c. Title 40 CFR, Part 763, “Asbestos.” Washington, DC:

U.S. Government Printing Office.

DOE, see U.S. Department of Energy.

DOE/NV, see U.S. Department of Energy, Nevada Operations Office.

DRI, see Desert Research Institute.

Desert Research Institute. 2000. Survival Town: The Apple-2 Historic District, Nevada Test Site, Nye County, Nevada. September. Prepared for the U.S. Department of Energy, Nevada Operations Office. Las Vegas, NV. 
Dickson, H.W., Reynolds Electrical \& Engineering Co., Inc. 1992. Letter to J.K. Magruder entitled, "Request for Plan on the Inventory of Inactive and Abandoned Waste Sites on the Nevada Test Site (NTS),” 9 April. U.S. Department of Energy. Las Vegas, NV.

EPA, see U.S. Environmental Protection Agency.

FFACO, see Federal Facility Agreement and Consent Order.

Fahringer, P., Stoller-Navarro Joint Venture. 2004. Memorandum to E. Shupp (SNJV) entitled, “CAS 01-02-01 Geophysics-Memorandum of Findings, April 2004,” 28 April. Las Vegas, NV.

Federal Facility Agreement and Consent Order. 1996 (as amended February 2008). Agreed to by the State of Nevada; U.S. Department of Energy, Environmental Management; U.S. Department of Defense; and U.S. Department of Energy, Legacy Management.

H\&N see Holmes \& Narver, Inc.

Haworth, O., Bechtel Nevada. 1990. Letter entitled "Notification to Nevada Department of Environmental Protection (NDEP) of Tank Closures and Upgrades.” 17 December. Las Vegas, NV.

Holmes \& Narver, Inc. 1960. Facilities Brochure of the Nevada Test Site for the United States Atomic Energy Commission. Prepared for the U.S. Atomic Energy Commission.

IT, see IT Corporation.

IT Corporation. 1997. “Radiological Survey, ER Spills/Background Sampling,” 28 August. Las Vegas, NV.

IT Corporation. 2002. “Radiological Survey Form Completed by C. Speer,” 16 August. Las Vegas, NV.

Madsen, D., National Security Technologies, LLC. 2007. Correspondence with C. Hall (SNJV) regarding CASs 01-02-01 and 10-02-01, 3 January. Las Vegas, NV.

Moore, J., Science Applications International Corporation. 1999. Memorandum to M. Todd (SAIC) entitled, “Background Concentrations for NTS and TTR Soil Samples,” 3 February. Las Vegas, NV: IT Corporation.

Morrell, D., SN Technologies. 2006. Record of Telecon with D. Siekerman (SNJV) regarding Bunker 7-235, 23 October. Las Vegas, NV. 
Murphy, T., Bureau of Federal Facilities. 2004. Letter to R. Bangerter (NNSA/NSO) entitled, "Review of Industrial Sites Project Document Guidance for Calculating Industrial Sites Project Remediation Goals for Radionuclides in Soil Using the Residual Radiation (RESRAD) Computer Code.” 19 November. Las Vegas, NV.

NAC, see Nevada Administrative Code.

NBMG, see Nevada Bureau of Mines and Geology.

NCRP, see National Council on Radiation Protection and Measurements.

NDEP, see Nevada Division of Environmental Protection.

NNSA/NSO, see U.S. Department of Energy, National Nuclear Security Administration Nevada Site Office.

NNSA/NV, see U.S. Department of Energy, National Nuclear Security Administration Nevada Operations Office.

NRS, see Nevada Revised Statutes.

National Council on Radiation Protection and Measurements. 1999. Recommended Screening Limits for Contaminated Surface Soil and Review of Factors Relevant to Site-Specific Studies, NCRP Report No. 129. Bethesda, MD.

Nevada Administrative Code. 2006a. NAC 444, "Sanitation.” Carson City, NV. As accessed at http://www.leg.state.nv.us/nac on 26 March 2008.

Nevada Administrative Code. 2006b. NAC 445A.22705, “Contamination of Soil: Evaluation of Site by Owner or Operator; Review of Evaluation by Division.” As accessed at http://www.leg.state.nv.us/nac on 26 March 2008.

Nevada Administrative Code. 2006c. NAC 445A.227, “Contamination of Soil: Order by Director for Corrective Action; Factors To Be Considered in Determining Whether Corrective Action Required.” As accessed at http://www.leg.state.nv.us/nac on 26 March 2008.

Nevada Administrative Code. 2006d. NAC 445A.2272, "Contamination of Soil: Establishment of Action Levels.” Carson City, NV. As accessed at http://www.leg.state.nv.us/nac on 26 March 2008.

Nevada Administrative Code. 2007. NAC 459.9972, “Assessment Required before Closure of Tank; Removal of Tank from Ground.” Carson City, NV. As accessed at http//www/leg.state.nv/nac on 26 March 2008. 
Nevada Bureau of Mines and Geology. 1998. Mineral and Energy Resource Assessment of the Nellis Air Force Range, Open-File Report 98-1. Reno, NV.

Nevada Division of Environmental Protection. 1995. Mutual Consent Agreement between the State of Nevada and the U.S. Department of Energy for the Storage of Low-Level Land Disposal Restricted Mixed Waste. Carson City, NV.

Nevada Division of Environmental Protection. 2005. State of Nevada Water Pollution Control General Permit, No. GNEV93001, Rev. 3iv. Carson City, NV.

Nevada Division of Environmental Protection. 2006a. Class II Solid Waste Disposal Site for Municipal and Solid Waste, Area 23 of the NTS, Permit SW 13.097.04, Rev. 5. Carson City, NV.

Nevada Division of Environmental Protection. 2006b. Class III Solid Waste Disposal Site for Hydrocarbon Burdened Soils, Area 6 of the NTS, Permit SW 13.097.02, Rev. 7. Carson City, NV.

Nevada Division of Environmental Protection. 2006c. Class III Solid Waste Disposal Site; U10c, Area 9 of the NTS, Permit SW 13.097.03, Rev. 7. Carson City, NV.

Nevada Revised Statutes. 2007a. NRS 444.440 - 444.620, “Collection and Disposal of Solid Waste.” Carson City, NV.

Nevada Revised Statutes. 2007b. NRS 459.400 - 459.600, “Disposal of Hazardous Waste.” Carson City, NV.

Nevada Revised Statutes. 2007c. NRS 618.750 - 618.840, “Disposal of Hazardous Waste.” Carson City, NV.

Nicosia, W., Stoller-Navarro Joint Venture. 2003. Memorandum to M. England (SAIC) entitled, "Radiological Land Area Surveys of Various Locations at the Nevada Test Site for Preliminary Assessments,” 3 March.

PNNL, see Pacific Northwest National Laboratory.

Paar, J.G., and D.R. Porterfield. 1997. Evaluation of Radiochemical Data Usability, ES/ER/MS-5. April. Oak Ridge, TN: U.S. Department of Energy.

Pacific Northwest National Laboratory. 2005. Visual Sampling Plan Version 4.0, User's Guide PNNL-14002. Richland, WA.

REECo, see Reynolds Electrical \& Engineering Co., Inc.

RSL, see Remote Sensing Laboratory. 
Remote Sensing Laboratory. 1989. Aerial photograph “6611-150,” 23 September. Las Vegas, NV: EG\&G Energy Measurements, Inc.

Remote Sensing Laboratory. 1994. Aerial photograph “7876-151,” 28 August. Las Vegas, NV: EG\&G Energy Measurements, Inc.

Remote Sensing Laboratory. 1998. Aerial photograph “9997-4,” 14 March. Las Vegas, NV: DOE-RSL.

Remote Sensing Laboratory. 1999. Aerial photograph “9997-4,” 14 March. Las Vegas, NV: DOE-RSL.

Reynolds Electrical \& Engineering Co., Inc. 1991. Nevada Test Site Inventory of Inactive and Abandoned Facilities and Waste Sites, Areas 5-10, Volume 2 of 5, DOE/NV/10630-18. Las Vegas, NV.

Reynolds Electrical \& Engineering Co., Inc. 1992a. Draft Action Plan to Characterize and Remediate the Remaining Sites Listed in the NTS Inventory of Inactive and Abandoned Facilities and Waste Sites. June. Prepared for the U.S. Department of Energy, Environmental Restoration and Waste Management Division. Las Vegas, NV.

Reynolds Electrical \& Engineering Co., Inc. 1992b. Detailed Site Activity Summary NTS Cleanup and Restoration, 14 May. Las Vegas, NV.

SAIC see Scientific Applications International Corporation.

Shaw, see Shaw Environmental and Infrastructure, Inc.

SNJV GIS, see Stoller-Navarro Joint Venture Geographic Information Systems.

Scientific Applications International Corporation. 2003. Surface Geophysical Survey Final Report Corrective Action Units Nevada Test Site, SAIC Project 01-1030-08-2013-018. May. Prepared for SHAW Environmental, Inc. Las Vegas, NV.

Shaw Environmental and Infrastructure, Inc. 2002. Results of Geophysical Survey, Selected FFACO Sites, Nevada Test Site (NTS), 27 September. Sacramento, CA.

Stoller-Navarro Joint Venture Geographic Information Systems. 2007. ESRI ArcGIS Software.

Stoller-Navarro Joint Venture Geographic Information Systems. 2008. ESRI ArcGIS Software.

USACE, see U.S. Army Corps of Engineers. 
U.S. Army Corps of Engineers. 1994. Camp Desert Rock INPR website. As accessed at http://dogbert.ncr.usace.army.mil/military/derp/fuds/projects/cpdesert/preasses/inpr/inpr.htmon 13 February 2008.

U.S. Department of Energy. 1993. Radiation Protection of the Public and the Environment, DOE Order 5400.5, Change 2. Washington, DC: U.S. Government Printing Office.

U.S. Department of Energy. 1997. The Procedures Manual of the Environmental Measurements Laboratory, HASL-300, 28th Ed., Vol. I. New York, NY.

U.S. Department of Energy, National Nuclear Security Administration Nevada Operations Office. 2002a. Industrial Sites Quality Assurance Project Plan, Nevada Test Site, Nevada, Rev. 3, DOE/NV--372. Las Vegas, NV.

U.S. Department of Energy, National Nuclear Security Administration Nevada Operations Office. 2002b. Nevada Test Site Orthophoto Site Atlas, DOE/NV/11718--604. Prepared by Bechtel Nevada. Las Vegas, NV.

U.S. Department of Energy, National Nuclear Security Administration Nevada Site Office. 2004. NV/YMP Radiological Control Manual, Rev. 5, DOE/NV/11718-079, UC-702. Prepared by A.L. Gile of Bechtel Nevada. Las Vegas, NV.

U.S. Department of Energy, National Nuclear Security Administration Nevada Site Office. 2006a. Industrial Sites Project Establishment of Final Action Levels, DOE/NV--1107, Rev. 0. Las Vegas, NV.

U.S. Department of Energy, National Nuclear Security Administration Nevada Site Office. 2006b. Nevada Test Site Waste Acceptance Criteria, DOE/NV--325, Rev. 6-02. Las Vegas, NV

U.S. Department of Energy, Nevada Operations Office. 2000. Nevada Test Site, NV Digital Orthophoto Quadrangles showing approximate location of CAS 07-02-01, 26 August. Las Vegas, NV.

U.S. Environmental Protection Agency. 1980. Prescribed Procedures for Measurement of Radioactivity in Drinking Water, EPA 600/4-80-032. Washington, DC.

U.S. Environmental Protection Agency. 1996. Test Method for Evaluating Solid Waste Physical/Chemical Methods, SW-846, 3rd Edition. Washington, DC.

U.S. Environmental Protection Agency. 2002. Guidance for Quality Assurance Project Plans, EPA QA/G5. Washington, DC.

U.S. Environmental Protection Agency. 2004a. USEPA Contract Laboratory Program National Functional Guidelines for Inorganic Data Review. Washington, DC. 
U.S. Environmental Protection Agency. 2004b. Region 9 Preliminary Remediation Goals (PRGs). As accessed at http://www.epa.gov/region09/waste/sfund/prg/index.htm on 26 March 2008. Prepared by S.J. Smucker. San Francisco, CA.

U.S. Environmental Protection Agency. 2006. EPA Guidance on Systematic Planning Using the Data Quality Objectives Process, EPA QA/G-4. Washington, DC. 


\section{Appendix A}

\section{Project Organization}




\section{A.1.0 Project Organization}

The NNSA/NSO Federal Sub-Project Manager Kevin Cabble, who can be reached at (702) 295-5000. The NNSA/NSO Task Manager is Janis Romo, who can be reached at (702) 295-0838.

The identification of the project Health and Safety Officer and the Quality Assurance Officer can be found in the appropriate plan. However, personnel are subject to change and it is suggested that the NNSA/NSO Federal Sub-Project Manager be contacted for further information. The Task Manager will be identified in the FFACO Monthly Activity Report before the start of field activities. 


\section{Appendix B}

\section{Data Quality Objective Process}




\section{B.1.0 Introduction}

The DQO process described in this appendix is a seven-step strategic systematic planning method used to plan data collection activities and define performance criteria for the CAU 130, Storage Tanks, field investigation. The DQOs are designed to ensure that the data collected will provide sufficient and reliable information to determine the appropriate corrective actions, verify the adequacy of existing information, provide sufficient data to implement the corrective actions, and verify that closure was achieved.

The CAU 130 investigation will be based on the DQOs presented in this appendix as developed by representatives of the NDEP and NNSA/NSO. The seven steps of the DQO process presented in Sections B.2.0 through B.8.0 were developed in accordance with EPA Guidance on Systematic Planning Using the Data Quality Objectives Process (EPA, 2006) and the CAS-specific information presented in Section B.2.0.

The DQO process for CAU 130 presents a judgmental sampling approach. In general, the procedures used in the DQO process provide:

- A method to establish performance or acceptance criteria, which serve as the basis for designing a plan for collecting data of sufficient quality and quantity to support the goals of a study.

- Criteria that will be used to establish the final data collection design such as:

- The nature of the problem that has initiated the study and a conceptual model of the environmental hazard to be investigated

- The decisions or estimates that need to be made and the order of priority for resolving them

- The type of data needed

- An analytic approach or decision rule that defines the logic for how the data will be used to draw conclusions from the study findings

- Acceptable quantitative criteria on the quality and quantity of the data to be collected, relative to the ultimate use of the data. 
- A data collection design that will generate data meeting the quantitative and qualitative criteria specified. A data collection design specifies the type, number, location, and physical quantity of samples and data, as well as the QA and QC activities that will ensure that sampling design and measurement errors are managed sufficiently to meet the performance or acceptance criteria specified in the DQOs. 


\section{B.2.0 Step 1 - State the Problem}

Step 1 of the DQO process defines the problem that requires study, identifies the planning team, and develops a conceptual model of the environmental hazard to be investigated.

The problem statement for the CAU 130 CASs is: "Existing information on the nature and extent of potential contamination is insufficient to evaluate and confirm closure of the individual CASs in CAU 130.”

\section{B.2.1 Planning Team Members}

The DQO planning team consists of representatives from NDEP, NNSA/NSO, Stoller-Navarro Joint Venture (SNJV), and National Security Technologies, LLC (NSTec). The DQO planning team met on April 3, 2008, for the DQO meeting. The primary decision-makers are NDEP and NNSA/NSO representatives.

\section{B.2.2 Conceptual Site Model}

The CSM is used to organize and communicate information about site characteristics. It reflects the best interpretation of available information at any point in time. The CSM is a primary vehicle for communicating assumptions about release mechanisms, potential migration pathways, or specific constraints. It provides a summary of how and where contaminants are expected to move and what impacts such movement may have. It is the basis for assessing how contaminants could reach receptors both in the present and future. The CSM describes the most probable scenario for current conditions at each site and defines the assumptions that are the basis for identifying appropriate sampling strategy and data collection methods. Accurate CSMs are important as they serve as the basis for all subsequent inputs and decisions throughout the DQO process.

The CSM was developed for CAU 130 using information from the physical setting, potential contaminant sources, release information, historical background information, knowledge from similar sites, and physical and chemical properties of the potentially affected media and COPCs. 
The CSM consists of:

- Potential contaminant releases including media subsequently affected.

- Release mechanisms (the conditions associated with the release).

- Potential contaminant source characteristics, including contaminants suspected to be present and contaminant-specific properties.

- Site characteristics including physical, topographical, and meteorological information.

- Migration pathways and transport mechanisms that describe the potential for migration and where the contamination may be transported.

- The locations of points of exposure where individuals or populations may come in contact with a COC associated with a CAS.

- $\quad$ Routes of exposure where contaminants may enter the receptor.

If additional elements are identified during the investigation that are outside the scope of the CSM, the situation will be reviewed and a recommendation will be made as to how to proceed. In such cases, NDEP and NNSA/NSO will be notified and given the opportunity to comment on, and concur with, the recommendation.

The applicability of the CSM to each CAS is summarized in Figure B.2-1 and discussed below. Table B.2-1 provides information on CSM elements that will be used throughout the remaining steps of the DQO process. Figure B.2-2 represents site conditions applicable to this CSM.

\section{B.2.2.1 Contaminant Release}

The most likely locations of the contamination and releases to the environment are the soils directly below or adjacent to the CSM's surface and subsurface components (i.e., potential USTs, associated underground piping, concrete pads). The CSM accounts for potential releases resulting from overflow of system components that are present at the ground surface (e.g., fill ports for USTs) and surface spills. Any contaminants migrating from CASs, regardless of physical or chemical characteristics, are expected to exist at interfaces, and in the soil adjacent to disposal features in lateral and vertical directions. 


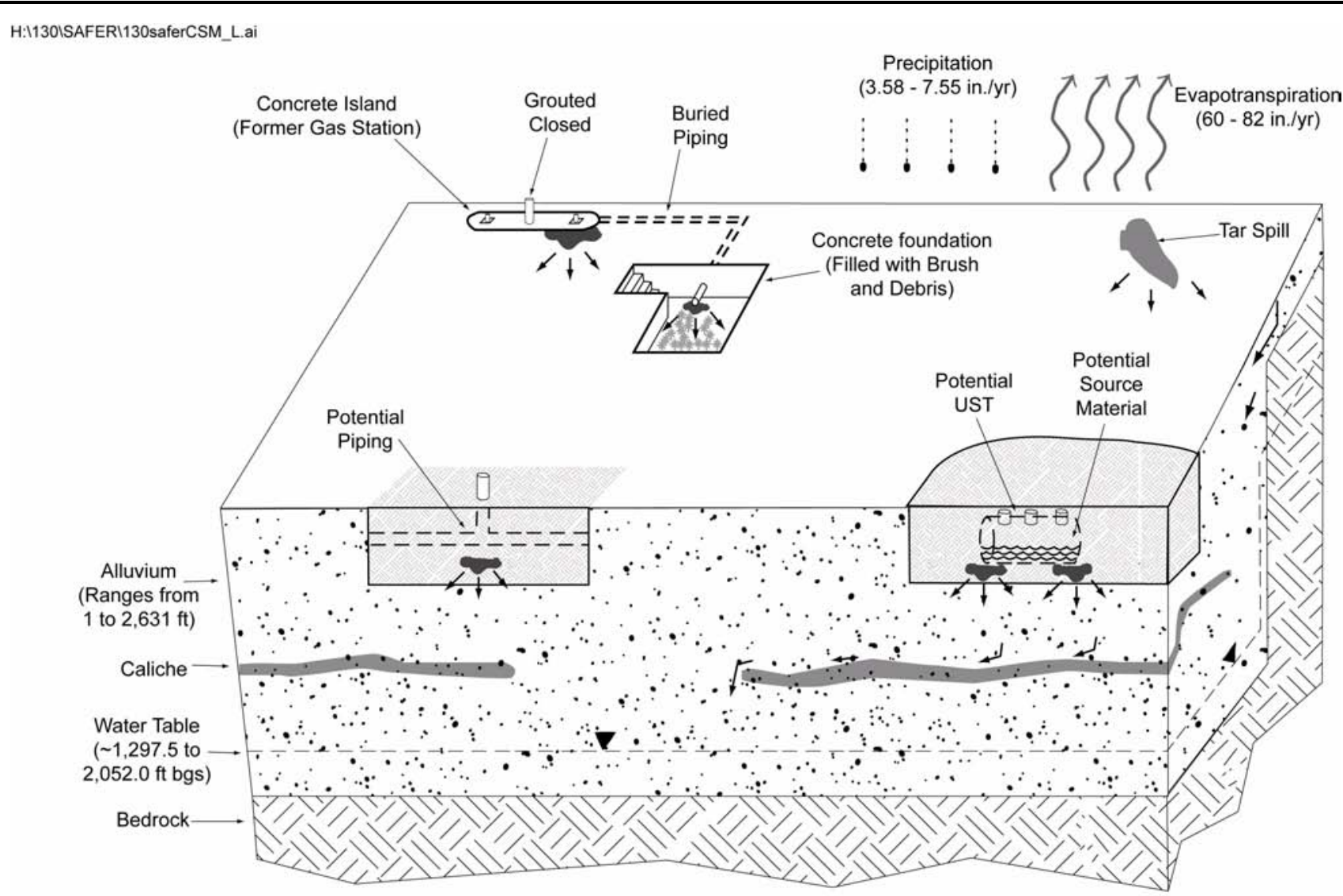

\section{Explanation \\ $\rightarrow$ Subsurface Transport \\ $\Rightarrow$ Surface Transport \\ Potential Plume \\ Disturbed Soil \\ Buried Debris \\ Not to Scale}

Figure B.2-1

Conceptual Site Model for CAU 130 CASs 
Table B.2-1

Conceptual Site Model Description of Elements for Each CAS in CAU 130

(Page 1 of 2)

\begin{tabular}{|c|c|c|c|c|c|c|c|}
\hline CAS Identifier & 01-02-01 & $07-02-01$ & $10-02-01$ & $20-02-03$ & $20-99-05$ & $22-02-02$ & 23-02-07 \\
\hline CAS Description & $\begin{array}{l}\text { Underground } \\
\text { Storage Tank }\end{array}$ & $\begin{array}{l}\text { Underground } \\
\text { Storage Tanks }\end{array}$ & $\begin{array}{l}\text { Underground } \\
\text { Storage Tank }\end{array}$ & $\begin{array}{l}\text { Underground } \\
\text { Storage Tank }\end{array}$ & Tar Residue & $\begin{array}{l}\text { Buried UST } \\
\text { Piping }\end{array}$ & $\begin{array}{l}\text { Underground } \\
\text { Storage Tank }\end{array}$ \\
\hline Site Status & \multicolumn{7}{|c|}{ Sites are inactive and/or abandoned } \\
\hline Exposure Scenario & \multicolumn{6}{|c|}{ Occasional Use Area(s) } & $\begin{array}{c}\text { Industrial Use } \\
\text { Area }\end{array}$ \\
\hline $\begin{array}{l}\text { Sources of Potential } \\
\text { Soil Contamination }\end{array}$ & $\begin{array}{c}\text { Release } \\
\text { associated with } \\
\text { the contents of } \\
\text { UST }\end{array}$ & $\begin{array}{c}\text { Release } \\
\text { associated with } \\
\text { the contents of } \\
\text { USTs and/or } \\
\text { instruments } \\
\text { Release } \\
\text { associated with } \\
\text { lead brick(s), } \\
\text { subsurface piping }\end{array}$ & $\begin{array}{c}\text { Release } \\
\text { associated with } \\
\text { the contents of } \\
\text { UST }\end{array}$ & $\begin{array}{c}\text { Release } \\
\text { associated with } \\
\text { the contents of } \\
\text { UST }\end{array}$ & $\begin{array}{c}\text { Release } \\
\text { associated with a } \\
\text { tar residue }\end{array}$ & $\begin{array}{c}\text { Release } \\
\text { associated with } \\
\text { the buried UST } \\
\text { piping }\end{array}$ & $\begin{array}{c}\text { Release } \\
\text { associated with } \\
\text { UST }\end{array}$ \\
\hline $\begin{array}{l}\text { Location of } \\
\text { Contamination/ } \\
\text { Release Point }\end{array}$ & $\begin{array}{l}\text { Surface (overfills) } \\
\text { and subsurface } \\
\text { (leaks) at or near } \\
\text { UST }\end{array}$ & $\begin{array}{c}\text { Surface and } \\
\text { subsurface at or } \\
\text { near Station 7-235, } \\
\text { UST and/or } \\
\text { instrumentation, } \\
\text { lead brick(s), } \\
\text { subsurface piping }\end{array}$ & $\begin{array}{c}\text { Surface (overfills) } \\
\text { and subsurface } \\
\text { (leaks) at or near } \\
\text { UST }\end{array}$ & $\begin{array}{l}\text { Surface (overfills) } \\
\text { and subsurface } \\
\text { (leaks) at or near } \\
\text { UST }\end{array}$ & $\begin{array}{c}\text { Surface and } \\
\text { shallow } \\
\text { subsurface at or } \\
\text { near tar }\end{array}$ & $\begin{array}{c}\text { Surface and } \\
\text { subsurface at or } \\
\text { near buried UST } \\
\text { piping and } \\
\text { concrete } \\
\text { structures }\end{array}$ & $\begin{array}{l}\text { Subsurface (leaks) } \\
\text { at or near UST }\end{array}$ \\
\hline Amount Released & Unknown & Unknown & Unknown & Unknown & Unknown & Unknown & Unknown \\
\hline Affected Media & \multicolumn{7}{|c|}{ Surface and shallow subsurface soil; debris such as concrete } \\
\hline $\begin{array}{c}\text { Potential } \\
\text { Contaminants }\end{array}$ & $\begin{array}{c}\text { VOCs, SVOCs, } \\
\text { TPH-GRO/DRO, } \\
\text { RCRA Metals, } \\
\text { Radionuclides }\end{array}$ & $\begin{array}{l}\text { VOCs, SVOCs, } \\
\text { RCRA Metals, } \\
\text { PCBs, } \\
\text { Radionuclides }\end{array}$ & $\begin{array}{c}\text { VOCs, SVOCs, } \\
\text { TPH-DRO/GRO, } \\
\text { RCRA Metals, } \\
\text { PCBs, } \\
\text { Radionuclides }\end{array}$ & $\begin{array}{l}\text { VOC, SVOCs, } \\
\text { TPH-DRO/ GRO, } \\
\text { RCRA Metals, } \\
\text { Radionuclides }\end{array}$ & $\begin{array}{l}\text { VOCs, SVOCs, } \\
\text { TPH-DRO }\end{array}$ & $\begin{array}{c}\text { VOCs, SVOCs, } \\
\text { TPH-GRO/DRO, } \\
\text { RCRA Metals }\end{array}$ & $\begin{array}{c}\text { VOCs, SVOCs, } \\
\text { TPH-DRO/GRO, } \\
\text { PCBs, RCRA } \\
\text { Metals }\end{array}$ \\
\hline
\end{tabular}


Table B.2-1

Conceptual Site Model Description of Elements for Each CAS in CAU 130

(Page 2 of 2)

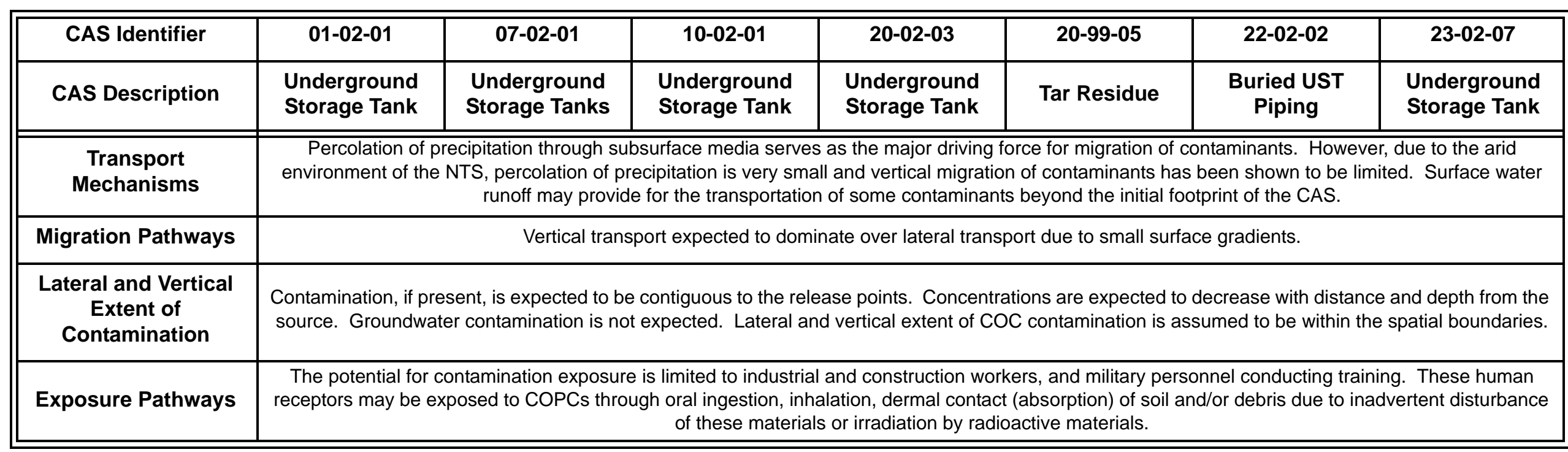

$\mathrm{COC}=$ Contaminant of concern

COPC $=$ Contaminant of potential concern

$\mathrm{DRO}=$ Diesel-range organics

GRO $=$ Gasoline-range organics

NTS = Nevada Test Site

$\mathrm{PCB}=$ Polychlorinated biphenyl
RCRA = Resource Conservation and Recovery Act

SVOC $=$ Semivolatile organic compound

$\mathrm{TPH}=$ Total petroleum hydrocarbons

UST = Underground storage tank

VOC $=$ Volatile organic compound 


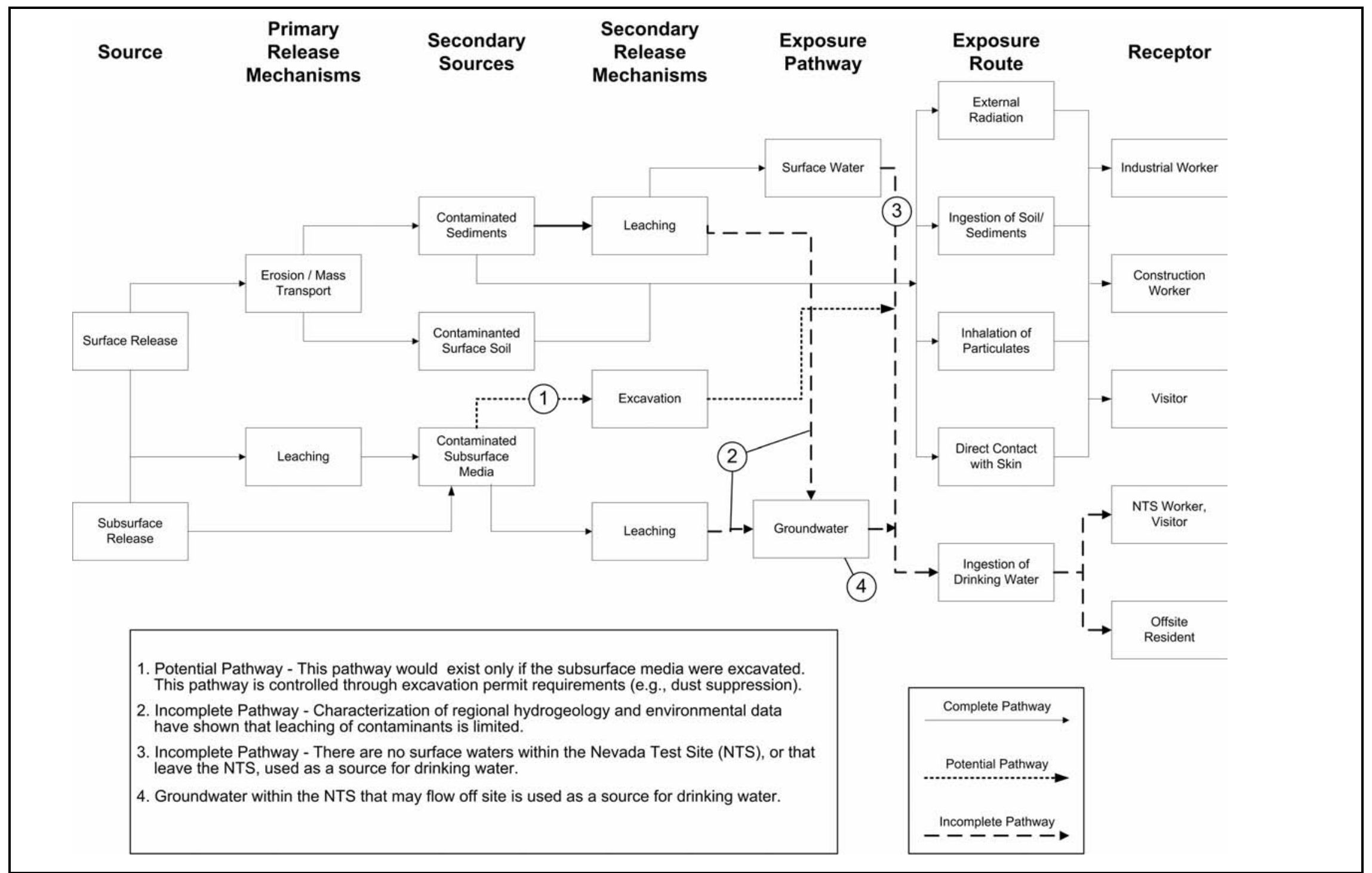

Figure B.2-2

Conceptual Site Model Diagram for CAU 130, Storage Tanks 


\section{B.2.2.2 Potential Contaminants}

The COPCs were identified during the planning process through the review of site history, process knowledge, personal interviews, past investigation efforts (where available), and inferred activities associated with the CASs. Because complete information regarding activities performed at the CAU 130 sites is not available, contaminants detected at similar NTS sites were included in the contaminant lists to reduce uncertainty. The list of COPCs is intended to encompass all of the contaminants that could potentially be present at each CAS. The COPCs applicable to Decision I environmental samples from each of the CASs of CAU 130 are defined as the constituents reported from the analytical methods stipulated in Table B.2-2.

During the review of site history documentation, process knowledge information, personal interviews, past investigation efforts (where available), and inferred activities associated with the CASs, some of the COPCs were identified as targeted contaminants at specific CASs. Targeted contaminants are those COPCs for which evidence in the available site and process information suggests that they may be reasonably suspected to be present at a given CAS. The targeted contaminants are required to meet a more stringent completeness criteria than other COPCs thus providing greater protection against a decision error (see Section B.2.2). Targeted contaminants for each CAU 130 CAS are identified in Table B.2-3.

\section{B.2.2.3 Contaminant Characteristics}

Contaminant characteristics include, but are not limited to: solubility, density, and adsorption potential. In general, contaminants with large particle size, low solubility, high affinity for media, and/or high density can be expected to be found relatively close to release points. Contaminants with small particle size, high solubility, low affinity for media, and/or low density are found further from release points or in low areas where evaporation of ponding will concentrate dissolved constituents. Volatile COPCs may impact the air, and COPCs contained in a liquid or are "dusts" dissolved by rainwater may infiltrate the subsoil. 
Table B.2-2

Analytical Program ${ }^{\mathrm{a}}$

(Includes Waste Characterization Analyses)

\begin{tabular}{|c|c|c|c|c|c|c|c|}
\hline Analyses & $\begin{array}{c}\text { CAS } \\
01-02-01\end{array}$ & $\begin{array}{c}\text { CAS } \\
07-02-01\end{array}$ & $\begin{array}{c}\text { CAS } \\
10-02-01\end{array}$ & $\begin{array}{c}\text { CAS } \\
20-02-03\end{array}$ & $\begin{array}{c}\text { CAS } \\
20-99-05\end{array}$ & $\begin{array}{c}\text { CAS } \\
22-02-02\end{array}$ & $\begin{array}{c}\text { CAS } \\
23-02-07\end{array}$ \\
\hline \multicolumn{8}{|c|}{ Organic Contaminants of Potential Concern (COPCs) } \\
\hline Volatile Organic Compounds & $\mathrm{X}$ & $\mathrm{X}$ & $\mathrm{X}$ & $\mathrm{X}$ & $\mathrm{X}$ & $\mathrm{X}$ & $\mathrm{X}$ \\
\hline Semivolatile Organic Compounds & $\mathrm{X}$ & $\mathrm{X}$ & $\mathrm{X}$ & $\mathrm{X}$ & $\mathrm{X}$ & $\mathrm{X}$ & $\mathrm{X}$ \\
\hline $\begin{array}{l}\text { Total Petroleum Hydrocarbons- } \\
\text { Gasoline-Range Organics }\end{array}$ & $\mathrm{X}$ & $\mathrm{X}$ & $\mathrm{X}$ & $\mathrm{X}$ & -- & $\mathrm{X}$ & $\mathrm{X}$ \\
\hline $\begin{array}{l}\text { Total Petroleum Hydrocarbons- } \\
\text { Diesel-Range Organics }\end{array}$ & $\mathrm{X}$ & $\mathrm{X}$ & $\mathrm{X}$ & $\mathrm{X}$ & $\mathrm{X}$ & $\mathrm{X}$ & $\mathrm{X}$ \\
\hline Polychlorinated Biphenyls & -- & $x$ & $x$ & -- & -- & -- & $\mathrm{X}$ \\
\hline \multicolumn{8}{|c|}{ Inorganic COPCs } \\
\hline $\begin{array}{c}\text { Resource Conservation and Recovery Act } \\
\text { Metals }\end{array}$ & $x$ & $x$ & $x$ & $x$ & $x$ & $x$ & $x$ \\
\hline \multicolumn{8}{|c|}{ Radionuclide COPCs } \\
\hline$\overline{\text { Gamma Spectroscopy }^{b}}$ & $\overline{\mathrm{X}}$ & $\overline{\mathrm{X}}$ & $\overline{\mathrm{X}}$ & $\overline{\mathrm{X}}$ & 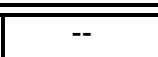 & $\overline{\mathrm{X}}$ & $\overline{\mathrm{X}}$ \\
\hline \multicolumn{8}{|c|}{ Waste Characterization Analyses (if necessary) } \\
\hline$\overline{\text { TCLP VOCS }}$ & $\overline{\mathrm{X}}$ & $\overline{\bar{X}}$ & $\overline{\mathrm{X}}$ & $\bar{X}$ & $\overline{\mathrm{X}}$ & $\bar{X}$ & $\overline{\mathrm{X}}$ \\
\hline TCLP SVOCS & $\mathrm{X}$ & $\mathrm{X}$ & $x$ & $\mathrm{X}$ & $x$ & $\mathrm{X}$ & $x$ \\
\hline TCLP RCRA Metals & $x$ & $x$ & $x$ & $x$ & $x$ & $\mathrm{X}$ & $x$ \\
\hline Total Pesticides & $\mathrm{X}$ & $\mathrm{X}$ & $\mathrm{X}$ & $\mathrm{X}$ & $\mathrm{X}$ & $\mathrm{X}$ & $\mathrm{X}$ \\
\hline Total Herbicides & $\mathrm{X}$ & $\mathrm{X}$ & $x$ & $\mathrm{X}$ & $\mathrm{X}$ & $x$ & $\mathrm{X}$ \\
\hline PCBs & $\mathrm{X}$ & $\mathrm{X}$ & $x$ & $x$ & $x$ & $x$ & $x$ \\
\hline TPH-DRO & $\mathrm{X}$ & $\mathrm{X}$ & $x$ & $x$ & $\mathrm{X}$ & $\mathrm{X}$ & $x$ \\
\hline TPH-GRO & $\mathrm{X}$ & $x$ & $x$ & $x$ & $x$ & $x$ & $x$ \\
\hline Gamma Spectroscopy & $\mathrm{x}$ & $\mathrm{X}$ & $x$ & $x$ & $x$ & $\mathrm{X}$ & $x$ \\
\hline Isotopic Uranium & $x$ & $x$ & $\bar{x}$ & $x$ & $\bar{x}$ & $x$ & $\bar{x}$ \\
\hline Isotopic Plutonium & $\mathrm{X}$ & $\mathrm{X}$ & $x$ & $\mathrm{X}$ & $x$ & $\mathrm{X}$ & $x$ \\
\hline Strontium-90 & $\mathrm{X}$ & $\mathrm{X}$ & $\mathrm{X}$ & $\mathrm{X}$ & $x$ & $\mathrm{X}$ & $x$ \\
\hline Gross Alpha/Gross Beta $^{c}$ & $\mathrm{X}$ & $\mathrm{X}$ & $\mathrm{X}$ & $\mathrm{X}$ & $\mathrm{X}$ & $x$ & $\mathrm{x}$ \\
\hline Tritium $^{c}$ & $x$ & $x$ & $\mathrm{X}$ & $x$ & $x$ & $x$ & $x$ \\
\hline
\end{tabular}

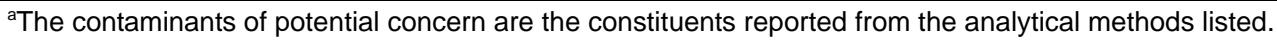

${ }^{\mathrm{b}}$ Results of gamma analysis will be used to determine whether further radioanalytical analysis is warranted.

${ }^{\circ} \mathrm{Gross}$ alpha/gross beta and tritium will only be taken on decontamination rinsate.

DRO = Diesel-range organics

$\mathrm{GRO}=$ Gasoline-range organics

$\mathrm{PCB}=$ Polychlorinated biphenyl

RCRA = Resource Conservation and Recovery Act

$\mathrm{X}=$ Required analytical method

$--=$ Not required
SVOC = Semivolatile organic compound

TCLP = Toxicity Characteristic Leaching Procedure

VOC $=$ Volatile organic compound 
Table B.2-3

Targeted Contaminants for CAU 130

\begin{tabular}{|c|c|c|}
\hline $\begin{array}{l}\text { Corrective Action } \\
\text { Site }\end{array}$ & $\begin{array}{l}\text { Targeted Chemical } \\
\text { Contaminants }\end{array}$ & $\begin{array}{c}\text { Targeted } \\
\text { Radiological } \\
\text { Contaminants }\end{array}$ \\
\hline 01-02-01 & $\begin{array}{l}\text { VOCS, SVOCs, } \\
\text { TPH-DRO }\end{array}$ & None \\
\hline 07-02-01 & $\begin{array}{l}\text { Lead (associated with } \\
\text { lead brick[s]) }\end{array}$ & None \\
\hline 10-02-01 & None & None \\
\hline $20-02-03$ & None & None \\
\hline 20-99-05 & $\begin{array}{l}\text { VOCs, SVOCs, } \\
\text { TPH-DRO }\end{array}$ & None \\
\hline $22-02-02$ & $\begin{array}{c}\text { VOCs, SVOCs, } \\
\text { TPH-GRO/DRO, Lead } \\
\text { (associated with } \\
\text { leaded gasoline) }\end{array}$ & None \\
\hline $23-02-07$ & $\begin{array}{l}\text { VOCS, SVOCs, } \\
\text { TPH-DRO }\end{array}$ & None \\
\hline $\begin{array}{l}\text { DRO = Diesel-range orgar } \\
\text { GRO = Gasoline-range or } \\
\text { SVOC = Semivolatile orga }\end{array}$ & \multicolumn{2}{|c|}{$\begin{array}{l}\text { TPH }=\text { Total petroleum hydrocarbons } \\
\text { VOC = Volatile organic compound }\end{array}$} \\
\hline
\end{tabular}

\section{B.2.2.4 Site Characteristics}

Site characteristics are defined by the interaction of physical, topographical, and meteorological attributes and properties. Physical properties include permeability, porosity, hydraulic conductivity, degree of saturation, sorting, chemical composition, and organic content. Topographical and meteorological properties and attributes include slope stability, precipitation frequency and amounts, precipitation runoff pathways, drainage channels and ephemeral streams, and evapotranspiration potential.

The structural geology of the NTS is complex. Thousands of normal faults throughout the area are responsible for the main characteristics of the Basin and Range topography (Winograd and Thordarson, 1975). Along with the normal faults, strike-slip faults and shear zones cut and offset thrust faults in several places within the NTS. Because the complexity of the structural geology, regional movement of groundwater may be influenced. 


\section{B.2.2.5 Migration Pathways and Transport Mechanisms}

Migration pathways of potential contaminants include lateral migration across surface soils/sediments and vertical migration of potential contaminants into and through subsurface soils.

Infiltration and percolation of precipitation serves as a driving force for downward migration of contaminants. Groundwater, however, is not expected to be impacted in the CAU 130 Areas $(1,7,10$, 20,22 , or 23) of the NTS. The inflitration of precipitation through subsurface media typically serves as the major driving force for migration of contaminants. Because of the arid environment of the NTS, percolation of precipitation is small, and migratin of potential contaminants has been shown to be limited. Evaporation potentials at the NTS range between 60 to 82 inches per year (in./yr), which significantly exceeds the NTS annual average precipitation. The annual average precipitation across the NTS ranges from 3.58 to $7.55 \mathrm{in} . / \mathrm{yr}$ (ARL/SORD, 2006).

Potential contaminants can be expected to be found relatively close to their release points, or in low areas where settling may occur and evaporation may concentrate the constituents. Given the relatively shallow relief at these CASs, lateral migration of potential contaminants of any major distance is unlikely. Because of the expected limited mobility, the affected media is typically the surface and shallow subsurface soil. Concentrations are expected to decrease with horizontal and vertical distance from the potential sources.

Infiltration of COPCs beyond shallow subsurface soil is not a concern at these CASs. While potential contaminants within weathered hydrocarbon spill/release may cover visible areas, they tend to be present in higher concentrations near the point of discharge and decrease with increased distance, both laterally and vertically.

\section{B.2.2.6 Exposure Scenarios}

Human receptors may be exposed to COPCs through oral ingestion, inhalation, dermal contact (absorption) of soil or debris due to inadvertent disturbance of these materials or irradiation by radioactive materials. The land-use and exposure scenarios for the CAU 130 CASs are listed in Table B.2-4. These are based on NTS current and future land use (DOE/NV, 1998). Although all CASs are located in areas where structures from past activities exist, no facilities are present that would allow these to be used as an assigned work station for NTS site personnel. However, as site 
personnel may periodically perform work at these sites, they are considered to be remote work areas. There is still the possibility, however, that site workers could occupy these locations on an occasional and temporary basis such as short-term maintenance activities or a military exercise. Therefore, these sites are classified as occasional work areas and industrial work areas.

Table B.2-4

\section{Land Use and Exposure Scenarios}

\begin{tabular}{|c|c|c|}
\hline $\begin{array}{l}\text { Corrective } \\
\text { Action Site }\end{array}$ & Record of Decision Land Use Zone & Exposure Scenario \\
\hline $23-02-07$ & $\begin{array}{l}\text { Reserved Zone } \\
\text { This area includes land and facilities that provide } \\
\text { widespread flexible support for diverse short-term } \\
\text { testing and experimentation. The reserved zone is also } \\
\text { used for short duration exercises and training such as } \\
\text { nuclear emergency response and Federal Radiological } \\
\text { Monitoring and Assessment Center training and } \\
\text { U.S. Department of Defense land-navigation exercises } \\
\text { and training. }\end{array}$ & $\begin{array}{c}\text { Industrial Area } \\
\text { Worker will be exposed to the site full time } \\
\text { (225 days per year, } 10 \text { hours per day for } 25 \\
\text { years). Active powered buildings with toilets } \\
\text { are present at the site. }\end{array}$ \\
\hline $22-02-02$ & $\begin{array}{l}\text { Solar Enterprise Zone } \\
\text { This area is designated for the development of a solar } \\
\text { power generation facility, and light industrial equipment } \\
\text { and commercial manufacturing capability. }\end{array}$ & \multirow{3}{*}{$\begin{array}{l}\text { Occasional Use Area } \\
\text { Worker will be exposed to the site occasionally } \\
\text { (up to } 80 \text { hours per year for } 5 \text { years). Site } \\
\text { structures are not present for shelter and } \\
\text { comfort of the worker }\end{array}$} \\
\hline $01-02-01$ & $\begin{array}{l}\text { Nuclear and High Explosives Test } \\
\text { This area is designated within the Nuclear Test Zone for } \\
\text { additional underground nuclear weapons tests and } \\
\text { outdoor high-explosive tests. This zone includes } \\
\text { compatible defense and nondefense research, } \\
\text { development, and testing activities. }\end{array}$ & \\
\hline $\begin{array}{l}07-02-01 \\
10-02-01 \\
20-02-03 \\
20-99-05\end{array}$ & $\begin{array}{l}\text { Nuclear Test } \\
\text { This area is reserved for dynamic experiments, } \\
\text { hydrodynamic tests, and underground nuclear weapons } \\
\text { and weapons effects tests. This zone includes } \\
\text { compatible defense and nondefense research, } \\
\text { development, and testing activities. }\end{array}$ & \\
\hline
\end{tabular}




\section{B.3.0 Step 2 - Identify the Goal of the Study}

Step 2 of the DQO process states how environmental data will be used in meeting objectives and solving the problem, identifies study questions or decision statement(s), and considers alternative outcomes or actions that can occur upon answering the question(s). Figure B.3-1 depicts the sequential flow of questions, answers, and action alternatives required to fulfill the objectives of the SAFER process.

\section{B.3.1 Decision Statements}

The Decision I statement is: “Is any COC present in environmental media within the CAS?” For judgmental sampling design, any analytical result for a COPC above the FAL will result in that COPC being designated as a COC. A COC may also be defined as a contaminant that, in combination with other like contaminants, is determined to jointly pose an unacceptable risk based on a multiple constituent analysis (NNSA/NSO, 2006). If a COC is detected, then Decision II must be resolved.

The Decision II statement is: "If a COC is present, is sufficient information available to meet the closure objectives?” Sufficient information is defined to include:

- Identifying the volume of media containing any COC bounded by analytical sample results in lateral and vertical directions.

- The information needed to characterize IDW and potential remediation waste for disposal.

- The information needed to evaluate the feasibility of remediation alternatives (bioassessment if natural attenuation or biodegradation is considered, and geotechnical data if construction or evaluation of barriers is considered).

A corrective action will be determined for any site containing a COC. The evaluation of the need for corrective action will include the potential for wastes that are present at a site to cause the future contamination of site environmental media if the wastes were to be released. To evaluate the potential for UST contents to result in the introduction of a COC to the surrounding environmental media, the following conservative assumptions were made:

- Any containment would fail at some point, and the contents would be released to the surrounding media. 


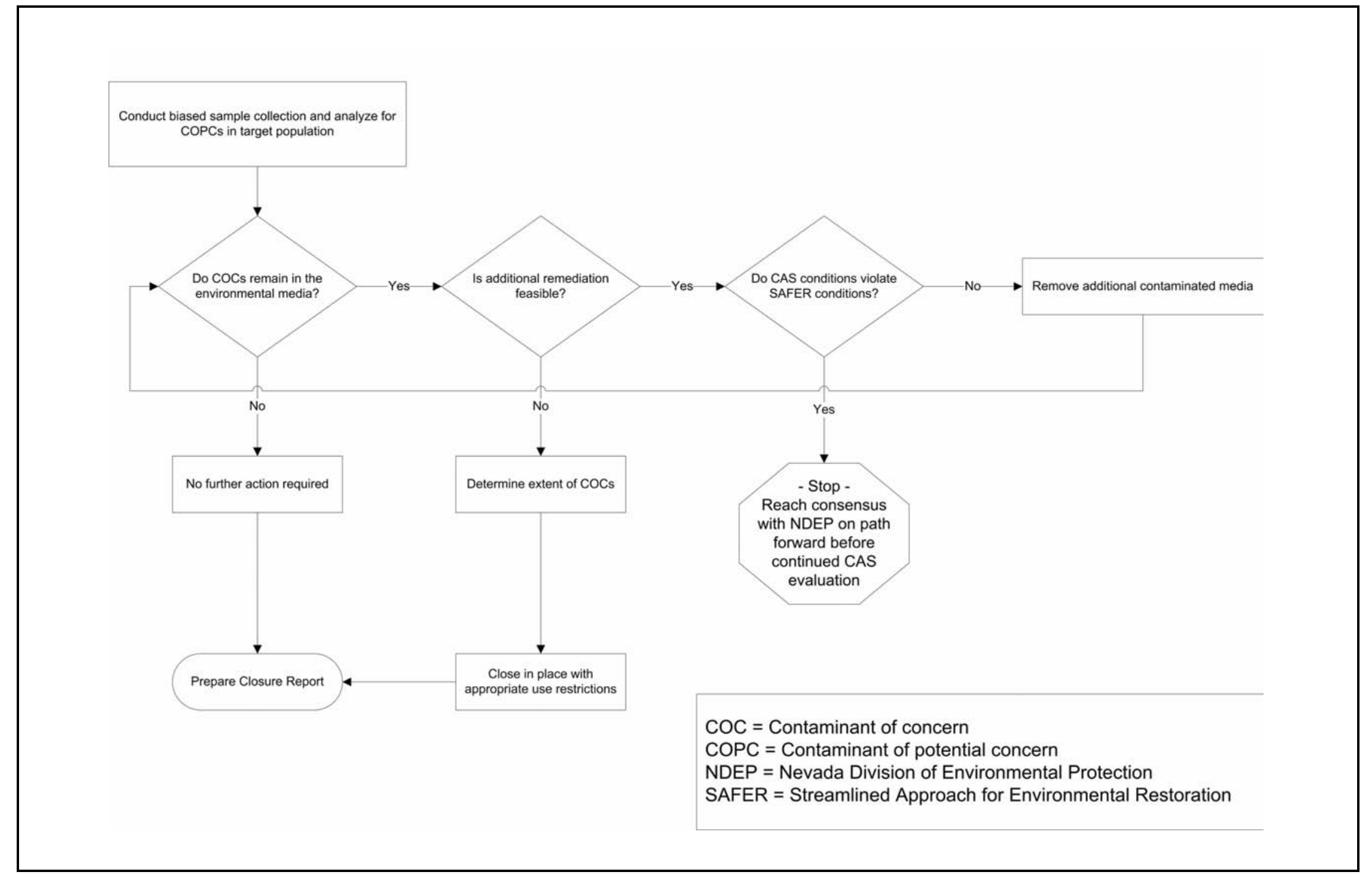

Figure B.3-1

SAFER Closure Decision Process for CAU 130 
- The resulting concentration of contaminants in the surrounding media would be equal to the concentration of contaminants in the tank waste.

- Any liquid contaminant in the UST exceeding the RCRA toxicity characteristic concentration would result in COCs in the surrounding media.

- If it is determined that the tar at CAS 20-99-05 is PSM (i.e., the tar contains a contaminant exceeding an equivalent FAL concentration), then a corrective action would be required (e.g., removal of the tar, if feasible).

The criteria for a non-liquid waste to be PSM is that it contains a contaminant exceeding an equivalent FAL concentration. The criteria for a liquid to be PSM is that it contains a contaminant concentration exceeding an equivalent toxicity characteristic action level. Any PSMs would require a corrective action.

If sufficient information is not available to meet the closure objectives, then site conditions will be re-evaluated and additional samples will be collected (as long as the scope of the investigation is not exceeded and any CSM assumption has not been shown to be incorrect).

\section{B.3.2 Alternative Actions to the Decisions}

This section identifies actions that may be taken to solve the problem depending on the possible outcomes of the investigation.

\section{B.3.2.1 Alternative Actions to Decision I}

If no COC associated with a release from the CAS is detected, then further assessment of the CAS is not required, and the corrective action alternative of no further action will be selected. If a COC associated with a release from the CAS is detected, then additional sampling will be conducted to determine the extent of COC contamination. If the extent of the contamination is defined and additional remediation is feasible, then clean close the site by removing the contaminated media until all contamination has been removed. If the extent of contamination has been determined and additional remediation is not feasible, then the extent of contamination will be defined and the contaminated area will be closed in place with appropriate use restrictions. 
If the collection of verification samples confirms that all the contaminated media has been removed, then the clean closure objectives will have been met. If contamination still exists and additional remediation would violate the conditions of the SAFER, then work will stop and a consensus reached with NDEP on the path forward before continuing the investigation of the CAS.

\section{B.3.2.2 Alternative Actions to Decision II}

If sufficient information is available to define the extent of the COCs and confirm that closure objectives were met, then further assessment of the CAS is not required. If sufficient information is not available to define the extent of contamination or confirm that closure objectives were met, then additional samples will be collected until the extent is defined. 


\section{B.4.0 Step 3 - Identify Information Inputs}

Step 3 of the DQO process identifies the information needed, determines sources for information, and identifies sampling and analysis methods that will allow reliable comparisons with FALs.

\section{B.4.1 Information Needs}

To resolve Decision I (determine whether a COC is present at a given CAS), samples need to be collected and analyzed following these two criteria:

- $\quad$ Samples must be collected in areas most likely to contain a COC (judgmental sampling).

- The analytical suite selected must be sufficient to identify any COCs present in the samples.

To resolve Decision II (determine whether sufficient information is available to confirm that closure objectives were met at each CAS), samples must be collected and analyzed to meet the following criteria:

- Samples must be collected in areas contiguous to the contamination but where contaminant concentrations are below FALs.

- Samples of the waste or environmental media must provide sufficient information to characterize the IDW for disposal.

- Samples of the waste or environmental media must provide sufficient information to determine potential remediation waste types.

- Samples of the waste in tanks must provide sufficient information to determine whether they contain PSM.

- Appropriate samples must be submitted to evaluate the feasibility of remediation alternatives (e.g., bioassessment if natural attenuation or biodegradation is considered, and geotechnical data if construction or evaluation of barriers is considered).

- The analytical suites selected must be sufficient to detect contaminants at concentrations equal to or less than their corresponding FALs. 


\section{B.4.2 Sources of Information}

Information to satisfy Decision I and Decision II will be generated by collecting environmental samples using grab sampling, hand auguring, backhoe excavation, or other appropriate sampling methods. These samples will be submitted to analytical laboratories meeting the quality criteria stipulated in the Industrial Sites QAPP (NNSA/NV, 2002). Only validated data from analytical laboratories will be used to make DQO decisions. Sample collection and handling activities will follow standard procedures.

\section{B.4.2.1 Sample Locations}

Design of the sampling approaches for the CAU 130 CASs must ensure that the data collected are of sufficient quantity and quality to support the selection of the corrective action alternatives (EPA, 2002). To meet this objective, the samples collected from each site should be from locations that most likely contain a COC, if present (judgmental), and properly represent any contamination at the CAS. These sample locations, therefore, can be selected by means of biasing factors used in judgmental sampling (e.g., a stain, likely containing a spilled substance). Because there is enough information available among the CAU 130 CASs, judgmental sampling approach are used for the CAI. Although some randomly chosen locations may be specified if biasing factors are absent, the sampling approach is considered judgmental.

\section{B.4.2.1.1 Judgmental Approach for Sampling Location Selection}

Decision I sample locations at CAU 130 CASs will be determined based upon the likelihood of the soil containing a COC, if present. Analytical suites for Decision I samples will include all COPCs identified in Table B.2-2.

The following field-screening biasing factors may be used to select biased sample locations at CAU 130:

- Walkover surface area radiological surveys: A radiological survey instrument will be used to detect locations of elevated radioactivity as permitted by terrain and field conditions.

- Documented process knowledge on source and location of release (e.g., volume). 
- Stains: Any spot or area on the soil surface that may indicate the presence of a potentially hazardous liquid. Typically, stains indicate an organic liquid such as oil.

- Geophysical anomalies: Any location identified during geophysical surveys that had results indicating surface or subsurface materials existed, and were not consistent with the natural surroundings (e.g., UST, buried concrete or metal, surface metallic objects).

- Drums, containers, equipment, or debris: Materials that may have been used at, or added to, a location, and that may have contained or come in contact with hazardous or radioactive substances at some point during their use.

- Lithology: Locations where variations in lithology (soil or rock) indicate that different conditions or materials exist.

- Preselected areas based on process knowledge of the site: Locations for which evidence such as historical photographs, experience from previous investigations, or interviewee's input exists that a release of hazardous or radioactive substances may have occurred.

- Preselected areas based on process knowledge of the contaminant(s): Locations that may reasonably have received contamination, selected on the basis of the chemical and/or physical properties of the contaminant(s) in that environmental setting.

- Previous sample results from the site being investigated.

- Experience and data from investigations of similar sites.

- Visual indicators such as discoloration, textural discontinuities, disturbance of native soils, or any other indication of potential contamination.

- Presence of debris, waste, or equipment.

- Odor.

- Physical and chemical characteristics of contaminants.

- Other biasing factors: Factors not previously defined for the CAI that become evident once the investigation of the site is under way.

Decision II sample step-out locations will be selected based on the CSM, biasing factors, and existing data. Analytical suites will include those parameters that exceeded FALs (i.e., COCs) in prior samples. Biasing factors to support Decision II sample locations include Decision I biasing factors plus available analytical results. 


\section{B.4.2.2 Analytical Methods}

Analytical methods are available to provide the data needed to resolve the decision statements. The analytical methods and laboratory requirements (e.g., detection limits, precision, and accuracy) are provided in Tables 3-4 and B.2-3. 


\section{B.5.0 Step 4 - Define the Boundaries of the Study}

Step 4 of the DQO process defines the target population of interest and its relevant spatial boundaries, specifies temporal and other practical constraints associated with sample/data collection, and defines the sampling units on which decisions or estimates will be made.

\section{B.5.1 Target Populations of Interest}

The population of interest to resolve Decision I ("Is any COC present in environmental media within the CAS?”) is any location within the site that is contaminated with any contaminant above a FAL (judgmental sampling). The populations of interest to resolve Decision II ("If a COC is present, is sufficient information available to evaluate potential corrective action alternatives?”) are:

- Each one of a set of locations bounding contamination in lateral and vertical directions.

- Investigation-derived waste or environmental media that must be characterized for disposal.

- $\quad$ Potential remediation waste.

- Environmental media where natural attenuation or biodegradation or construction/evaluation of barriers is considered.

\section{B.5.2 Spatial Boundaries}

Spatial boundaries are the maximum lateral and vertical extent of expected contamination at each CAS, as shown in Table B.5-1. Contamination found beyond these boundaries may indicate a flaw in the CSM and may require re-evaluation of the CSM before the investigation could continue. Each CAS is considered geographically independent, and intrusive activities are not intended to extend into the boundaries of neighboring CASs. 
Table B.5-1

Spatial Boundaries of CAU 130 CASs

\begin{tabular}{|c|c|}
\hline Corrective Action Site & Spatial Boundaries \\
\hline $01-02-01$ & $\begin{array}{l}\text { The footprint of the gas pipe and excavated area, plus an approximate } \\
\text { 100-foot (ft) lateral buffer, not including Test Buildings 1-31.1e and 1-31-4b; } \\
15 \mathrm{ft} \text { below ground surface (bgs) vertically }\end{array}$ \\
\hline $07-02-01$ & $\begin{array}{l}\text { The footprint of Station 7-235 and the two mounds, plus an approximate } \\
100 \text {-ft lateral buffer; } 15 \mathrm{ft} \text { bgs vertically }\end{array}$ \\
\hline $10-02-01$ & $\begin{array}{l}\text { The footprint of the concrete pad and visible piping, plus an approximate } \\
100 \text {-ft lateral buffer; } 15 \mathrm{ft} \text { bgs vertically }\end{array}$ \\
\hline $20-02-03$ & $\begin{array}{l}\text { Engineered planned location of underground storage tank (UST) and geophysical } \\
\text { located anomaly, plus an approximate } 100 \text {-ft lateral buffer from each location; } \\
15 \mathrm{ft} \text { bgs vertically }\end{array}$ \\
\hline 20-99-05 & $\begin{array}{l}\text { The footprint of the tar residue, plus an approximate 100-ft lateral buffer; } \\
\qquad 15 \mathrm{ft} \text { bgs vertically }\end{array}$ \\
\hline 22-02-02 & $\begin{array}{l}\text { The concrete gas island, concrete foundation with steps, and underground piping, } \\
\text { plus an approximate 100-ft lateral buffer; } 15 \mathrm{ft} \text { bgs vertically }\end{array}$ \\
\hline $23-02-07$ & Location of the UST, plus an approximate 100 -ft lateral buffer; $15 \mathrm{ft}$ bgs vertically \\
\hline
\end{tabular}

\section{B.5.3 Practical Constraints}

Practical constraints such as military activities at the NTS, utilities, threatened or endangered animal and plants, unstable or steep terrain, and/or access restrictions may affect the ability to investigate this site. The practical constraints associated with the investigation of the CAU 130 CASs are summarized in Table B.5-2.

\section{B.5.4 Define the Sampling Units}

The scale of decision making in Decision I is defined as the CAS. Any COC detected at any location within the CAS will cause the determination that the CAS is contaminated and needs further evaluation. The scale of decision making for Decision II is defined as a contiguous area contaminated with any COC originating from the CAS. Resolution of Decision II requires this contiguous area to be bounded laterally and vertically. 
Table B.5-2

Practical Constraints for the CAU 130 Field Investigation

\begin{tabular}{|c|c|}
\hline Corrective Action Site & Practical Constraints \\
\hline 01-02-01 & $\begin{array}{l}\text { Weather (i.e., high winds, rain, lightning, extreme heat); Test Buildings 1-31-1e and 1-31-4b } \\
\text { boundary; underground utilities; and loose and unconsolidated terrain }\end{array}$ \\
\hline 07-02-01 & $\begin{array}{l}\text { Weather (i.e., high winds, rain, lightning, extreme heat); posted "Contamination Area"; } \\
\text { loose and unconsolidated terrain; and underground utilities }\end{array}$ \\
\hline $10-02-01$ & $\begin{array}{l}\text { Weather (i.e., high winds, rain, lightning, extreme heat); underground utilities; and loose } \\
\text { and unconsolidated terrain }\end{array}$ \\
\hline $20-02-03$ & $\begin{array}{l}\text { Weather (i.e., high winds, rain, lightning, extreme heat); overhead and below ground } \\
\text { utilities; loose and uneven terrain; located near subsided crater and cliff to the west of CAS }\end{array}$ \\
\hline 20-99-05 & Weather (i.e., high winds, rain, lightning, extreme heat); loose and uneven terrain \\
\hline $22-02-02$ & $\begin{array}{c}\text { Weather (i.e, high winds, rain, lightning, extreme heat); located within the habitat range of } \\
\text { the desert tortoise }{ }^{\text {a; }} \text { underground utilities associated with gas station and former } \\
\text { underground storage tanks and uneven terrain }\end{array}$ \\
\hline 23-02-07 & $\begin{array}{c}\text { Weather (i.e., high winds, rain, lightning, warm temperatures); underground utilities, and } \\
\text { uneven terrain }\end{array}$ \\
\hline
\end{tabular}

aMojave Desert population of the desert tortoise is listed as a threatened species by the U.S. Fish and Wildlife Service (DOE/NV, 1996). 


\section{B.6.0 Step 5 - Develop the Analytic Approach}

Step 5 of the DQO process specifies appropriate population parameters for making decisions, defines action levels and generates an "If ... then ... else" decision rule that defines the conditions under which possible alternative actions will be chosen. This step also specifies the parameters that characterize the population of interest, specifies the FALs, and confirms that the analytical detection detection limits are capable of detecting FALs.

\section{B.6.1 Population Parameters}

For judgmental sampling results, the population parameter is the observed concentration of each contaminant from each individual analytical sample. Each sample result will be compared to the FALs to determine the appropriate resolution to Decision I and Decision II. For Decision I, a single sample result for any contaminant exceeding a FAL would cause a determination that a COC is present within the CAS.

The Decision II population parameter is an individual analytical result from a bounding sample. For Decision II, a single bounding sample result for any contaminant exceeding a FAL would cause a determination that the contamination is not bounded.

\section{B.6.2 Action Levels}

The PALs presented in this section are to be used for site screening purposes. They are not necessarily intended to be used as cleanup action levels or FALs. However, they are useful in screening out contaminants that are not present in sufficient concentrations to warrant further evaluation and, therefore, streamline the consideration of remedial alternatives. The RBCA process used to establish FALs is described in the Industrial Sites Project Establishment of Final Action Levels (NNSA/NSO, 2006). This process conforms with NAC Section 445A.227, which lists the requirements for sites with soil contamination (NAC, 2006a). For the evaluation of corrective actions, NAC Section 445A.22705 (NAC, 2006b) recommends the use of ASTM Method E 1739-95 (ASTM, 1995) to "conduct an evaluation of the site, based on the risk it poses to public health and the environment, to determine the necessary remediation standards (i.e., FALs) or to establish that corrective action is not necessary." 
This RBCA process defines three tiers (or levels) of evaluation involving increasingly sophisticated analyses:

- Tier 1 evaluation - Sample results from source areas (highest concentrations) are compared to action levels based on generic (non-site-specific) conditions (i.e., the PALs established in this SAFER Plan). The FALs may then be established as the Tier 1 action levels or the FALs may be calculated using a Tier 2 evaluation.

- Tier 2 evaluation - Conducted by calculating Tier 2 SSTLs using site-specific information as inputs to the same or similar methodology used to calculate Tier 1 action levels. The Tier 2 are then compared to individual sample results from reasonable points of exposure (as opposed to the source areas as is done in Tier 1) on a point-by-point basis. Total TPH concentrations will not be used for risk-based decisions under Tier 2 or Tier 3 . Rather, the individual COPC constituents of TPH-DRO will be compared to the SSTLs.

- Tier 3 evaluation - Conducted by calculating Tier 3 SSTLs on the basis of more sophisticated risk analyses using methodologies described in Method E 1739-95 that consider site-, pathway-, and receptor-specific parameters.

The comparison of laboratory results to FALs and the evaluation of potential corrective actions will be included in the investigation report. The FALs will be defined (along with the basis for their definition) in the investigation report.

\section{B.6.2.1 Chemical PALs}

Except as noted herein, the chemical PALs are defined as the EPA Region 9 Risk-Based Preliminary Remediation Goals (PRGs) for chemical contaminants in industrial soils (EPA, 2004). Background concentrations for RCRA metals and zinc will be used instead of PRGs when natural background concentrations exceed the PRG, as is often the case with arsenic on the NTS. Background is considered the average concentration plus two standard deviations of the average concentration for sediment samples collected by the Nevada Bureau of Mines and Geology throughout the Nevada Test and Training Range (formerly the Nellis Air Force Range) (NBMG, 1998; Moore, 1999). For detected chemical COPCs without established PRGs, the protocol used by the EPA Region 9 in establishing PRGs (or similar) will be used to establish PALs. If used, this process will be documented in the investigation report. 


\section{B.6.2.2 Total Petroleum Hydrocarbon PALs}

The PAL for TPH is 100 parts per million as listed in NAC 445A.2272 (NAC, 2006c).

\section{B.6.2.3 Radionuclide PALS}

The PALs for radiological contaminants are based on the NCRP Report No. 129 recommended screening limits for construction, commercial, industrial land-use scenarios (NCRP, 1999) scaled to 25-mrem/yr dose constraint (Murphy, 2004) and the generic guidelines for residual concentration of radionuclides in DOE Order 5400.5 (DOE, 1993). These PALs are based on the construction, commercial, and industrial land-use scenario provided in the guidance and are appropriate for the NTS based on future land use scenarios as presented in Section B.2.2.

\section{B.6.3 Decision Rules}

The decision rules applicable to both Decision I and Decision II are:

- If COC contamination is inconsistent with the CSM or extends beyond the spatial boundaries identified in Section B.5.2, then work will be suspended and the investigation strategy will be reconsidered, else the decision will be to continue sampling to define the extent.

The decision rules for Decision I are:

- If the population parameter of any COPC in the Decision I population of interest (defined in Step 4) exceeds the corresponding FAL - then that contaminant is identified as a COC, the contaminated material will be removed, or Decision II samples will be collected until an estimate of the extent of contaminated material has been made.

- If no COC associated with a release from the CAS is detected, then further assessment of the CAS is not required and the corrective action alternative of no further action will be selected. If a COC associated with a release from the CAS is detected, then additional sampling will be conducted to determine the extent of COC contamination. If the extent of the contamination is defined and additional remediation is feasible, then clean close the site by removing the contaminated media until all contamination has been removed. If the extent of contamination has been determined and additional remediation is not feasible, then the contaminated area will be close in place with appropriate use restrictions and the extent of contamination defined. 
- If a waste is present that, if released, has the potential to cause the future contamination of site environmental media at levels above the FALs, then a corrective action will be determined, else no further action will be necessary.

The decision rules for Decision II are:

- If the population parameter (the observed concentration of any COC) in the Decision II population of interest (defined in Step 4) exceeds the corresponding FAL, then additional samples will be collected to complete the Decision II evaluation. If sufficient information is available to define the extent of COC contamination and confirm that closure objectives were met, then further assessment of the CAS is not required. If sufficient information is not available to define the extent of contamination or confirm that closure objectives were met, then additional samples will be collected until the extent is defined.

- If valid analytical results are available for the waste characterization samples defined in Section B.8.0, then the decision will be that sufficient information exists to characterize the IDW for disposal and determine potential remediation waste types, else collect additional waste characterization samples. 


\section{B.7.0 Step 6 - Specify Performance or Acceptance Criteria}

Step 6 of the DQO process defines the decision hypotheses, specifies controls against false rejection and false acceptance decision errors, examines consequences of making incorrect decisions from the test, and places acceptable limits on the likelihood of making decision errors.

\section{B.7.1 Decision Hypotheses}

The baseline condition (i.e., null hypothesis) and alternative condition for Decision I are:

- Baseline condition - A COC is present.

- Alternative condition - A COC is not present.

The baseline condition (i.e., null hypothesis) and alternative condition for Decision II are as follows:

- Baseline condition - The extent of a COC has not been defined.

- Alternative condition - The extent of a COC has been defined.

Decisions and/or criteria have false negative or false positive errors associated with their determination. The impact of these decision errors and the methods that will be used to control these errors are discussed in the following subsections. In general terms, confidence in DQO decisions based on judgmental sampling results will be established qualitatively by:

- The development of and concurrence of CSMs (based on process knowledge) by stakeholder participants during the DQO process;

- Testing the validity of CSMs based on investigation results; and

- Evaluating the quality of the data based on DQI parameters.

\section{B.7.2 False Negative Decision Error}

The false negative decision error would mean deciding that a COC is not present when it actually is (Decision I), or deciding that the extent of a COC has been defined when it has not (Decision II). In both cases the potential consequence is an increased risk to human health and environment. 
In judgmental sampling, the selection of the number and location of samples is based on knowledge of the feature or condition under investigation and on professional judgment (EPA, 2002). Judgmental sampling conclusions about the target population depend upon the validity and accuracy of professional judgment.

The false negative decision error (where consequences are more severe) for judgmental sampling designs is controlled by meeting these criteria:

- For Decision I, having a high degree of confidence that the sample locations selected will identify COCs, if present, anywhere within the CAS. For Decision II, having a high degree of confidence that the sample locations selected will identify the extent of COCs.

- Having a high degree of confidence that analyses conducted will be sufficient to detect any COCs present in the samples.

- Having a high degree of confidence that the dataset is of sufficient quality and completeness.

To satisfy the first criterion, Decision I samples must be collected in areas most likely to be contaminated by COCs (supplemented by random samples where appropriate). Decision II samples must be collected in areas that represent the lateral and vertical extent of contamination (above FALs). The following characteristics must be considered to control decision errors for the first criterion:

- Source and location of release

- Chemical nature and fate properties

- Physical transport pathways and properties

- Hydrologic drivers

These characteristics were considered during the development of the CSMs and selection of sampling locations. The field-screening methods and biasing factors listed in Section B.4.2.1 will be used to further ensure that appropriate sampling locations are selected to meet these criteria. Radiological survey instruments and field-screening equipment will be calibrated and checked in accordance with the manufacturer's instructions and approved procedures. The investigation report will present an assessment on the DQI of representativeness that samples were collected from those locations that best represent the populations of interest as defined in Section B.5.1. 
To satisfy the second criterion, Decision I samples will be analyzed for the chemical and radiological parameters listed in Section 3.2 of this SAFER Plan. Decision II samples will be analyzed for those chemical and radiological parameters that identified unbounded COCs. The DQI of sensitivity will be assessed for all analytical results to ensure that all sample analyses had measurement sensitivities (detection limits) that were less than or equal to the corresponding FALs. If this criterion is not achieved, the affected data will be assessed (for usability and potential impacts on meeting site characterization objectives) in the investigation report.

To satisfy the third criterion, the entire dataset, as well as individual sample results, will be assessed against the DQIs of precision, accuracy, comparability, and completeness as defined in the Industrial Sites QAPP (NNSA/NV, 2002) and in Section 7.2 of this SAFER Plan. The DQIs of precision and accuracy will be used to assess overall analytical method performance as well as to assess the need to potentially "flag” (qualify) individual contaminant results when corresponding QC sample results are not within the established control limits for precision and accuracy. Data qualified as estimated for reasons of precision or accuracy may be considered to meet the constituent performance criteria based on an assessment of the data. The DQI for completeness will be assessed to ensure that all data needs identified in the DQO have been met. The DQI of comparability will be assessed to ensure that all analytical methods used are equivalent to standard EPA methods so that results will be comparable to regulatory action levels that have been established using those procedures. Strict adherence to established procedures and QA/QC protocol protects against false negatives. Site-specific DQIs are discussed in more detail in Section 7.2 of this SAFER Plan.

To provide information for the assessment of the DQIs of precision and accuracy, the following quality control samples will be collected as required by the Industrial Sites QAPP (NNSA/NV, 2002):

- Field duplicates (minimum of 1 per matrix per 20 environmental samples)

- Laboratory QC samples (minimum of 1 per matrix per 20 environmental samples or 1 per CAS per matrix, if less than 20 collected).

\section{B.7.3 False Positive Decision Error}

The false positive decision error would mean deciding that a COC is present when it is not, or a COC is unbounded when it is not, resulting in increased costs for unnecessary sampling and analysis. 
False positive results are typically attributed to laboratory and/or sampling/handling errors that could cause cross contamination. To control against cross contamination, decontamination of sampling equipment will be conducted according to established and approved procedures and only clean sample containers will be used. To determine whether a false positive analytical result may have occurred, the following quality control samples will be collected as required by the Industrial Sites QAPP (NNSA/NV, 2002):

- Trip blanks (1 sample [3 vials] per sample cooler containing VOC environmental samples)

- Equipment blanks (1 per sampling event for each type of decontamination procedure)

- Source blanks (1 per source lot per sampling event)

- Field blanks (minimum of 1 per CAS, additional if field conditions change) 


\section{B.8.0 Step 7 - Develop the Plan for Obtaining Data}

Step 7 of the DQO process selects and documents a design that will yield data that will best achieve performance or acceptance criteria. Judgmental sampling schemes will be implemented to select sample locations and evaluate analytical results for CAU 130. Sections B.8.1 through B.8.2 contain general information about collecting Decision I and Decision II samples under judgmental sampling designs, while the subsequent sections provide CAS-specific sampling activities, including proposed sample locations.

\section{B.8.1 Decision I Sampling}

A judgmental sampling design will be implemented for all of the CAU 130 CASs. Because individual sample results, rather than an average concentration, will be used to compare to FALs at the CASs undergoing judgmental sampling, statistical methods to generate site characteristics will not be used. Adequate representativeness of the entire target population may not be a requirement to developing a sampling design. If good prior information is available on the target site of interest, then the sampling may be designed to collect samples only from areas known to have the highest concentration levels on the target site. If the observed concentrations from these samples are below the action level, then a decision can be made that the site contains safe levels of the contaminant without the samples being truly representative of the entire area (EPA, 2006).

All sample locations will be selected to satisfy the DQI of representativeness in that samples collected from selected locations will best represent the populations of interest as defined in Section B.5.1. To meet this criterion for judgmentally sampled sites, a biased sampling strategy will be used for Decision I samples to target areas with the highest potential for contamination, if it is present anywhere in the CAS. Sample locations will be determined based on process knowledge, previously acquired data, or the field-screening and biasing factors listed in Section B.4.2.1. If biasing factors are present in soils below locations where Decision I samples were removed, additional Decision I soil samples will be collected at depth intervals selected by the Site Supervisor based on biasing factors to a depth where the biasing factors are no longer present. The Site Supervisor has the discretion to modify the judgmental sample locations, but only if the modified locations meet the decision needs and criteria stipulated in this DQO. 


\section{B.8.2 Decision II Sampling}

To meet the DQI of representativeness for Decision II samples (that Decision II sample locations represent the population of interest as defined in Section B.5.1), judgmental sampling locations at each CAS will be selected based on the outer boundary sample locations where COCs were detected, the CSM, and other field-screening and biasing factors listed in Section B.4.2. In general, sample locations will be arranged in a triangular pattern around the Decision I location or area at distances based on site conditions, process knowledge, and biasing factors. If COCs extend beyond the initial step-outs, Decision II samples will be collected from incremental step-outs. Initial step-outs will be at least as deep as the vertical extent of contamination defined at the Decision I location and the depth of the incremental step-outs will be based on the deepest contamination observed at all locations. A clean sample (i.e., COCs less than FALs) collected from each step-out direction (lateral or vertical) will define extent of contamination in that direction. The number, location, and spacing of step-outs may be modified by the Site Supervisor, as warranted by site conditions as long as the modifications meet the requirements of the DQOs.

\section{B.8.3 Corrective Action Site 01-02-01, Underground Storage Tank}

The judgmental sample locations at CAS 01-02-01 have been selected based on the 4-in. steel pipe at ground surface with a lid that reads "GAS," and the slightly disturbed soils surrounding the pipe.

Figure B.8-1 shows the proposed sample strategy for CAS 01-02-01. A Decision I sample will be collected at the surface contact beside the exposed pipe. A backhoe will excavate within the area of the UST to determine whether a UST is present. If a UST is present, then the following additional sampling will be conducted:

- The contents, if any, of each phase inside the UST will be sampled.

- $\quad$ One soil sample will be collected under each end of the base of the UST.

- One soil sample will be collected from below the inlet, and one soil sample will be collected from below the outlet piping of the tank, if these features are present.

- Additional Decision I samples may be collected based on biasing factors during excavation.

- $\quad$ The UST will be closed in accordance with NAC Section 459.9972 (NAC, 2007). 


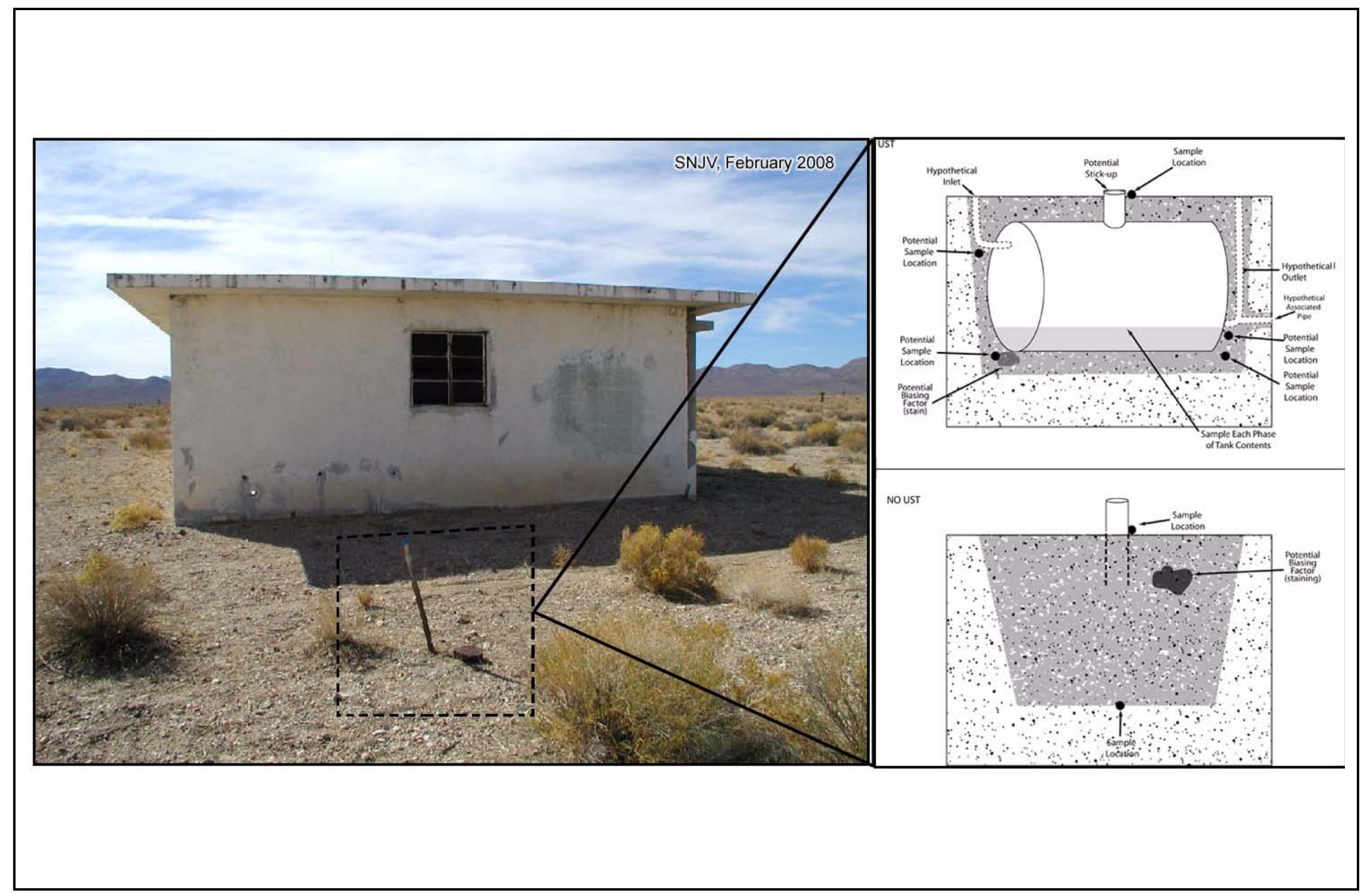

Figure B.8-1

Proposed Sample Strategy at CAS 01-02-01 
- The UST contents, if any, will be disposed of in accordance with Section 6.0 of this SAFER Plan.

If no UST is present, the excavated material will be observed for biasing factors, such as staining to the undisturbed native soil interface. If no biasing factors are observed, then the following additional sampling will be conducted:

- One soil sample will be collected at the undisturbed native soil interface.

- If the undisturbed native soil interface cannot be determined, one soil sample will be collected at approximately $4 \mathrm{ft}$ bgs, and one soil sample will be collected at approximately $6 \mathrm{ft}$ bgs.

Samples will be submitted for analysis in accordance with the analytical program listed in Table 3-1.

\section{B.8.4 Corrective Action Site 07-02-01, Underground Storage Tanks}

The judgmental sample locations at CAS 07-02-01 have been selected based on Station 7-235, the lead brick, and the results of the geophysical survey.

Figure B.8-2 shows the proposed sample strategy for CAS 07-02-01. A backhoe will excavate within the areas of the potential USTs. If USTs are present, then the following additional sampling will be conducted:

- The contents, if any, of each phase inside the UST will be sampled.

- One soil sample will be collected under each end of the base of the UST.

- One soil sample will be collected from below the inlet, and one soil sample will be collected from below the outlet piping of the tank if these features are present.

- Additional Decision I samples may be collected based on biasing factors during excavation.

- The UST will be closed in accordance with NAC Section 459.9972 (NAC, 2007).

- The UST contents, if any, will be disposed of in accordance with Section 6.0 of this SAFER Plan. 


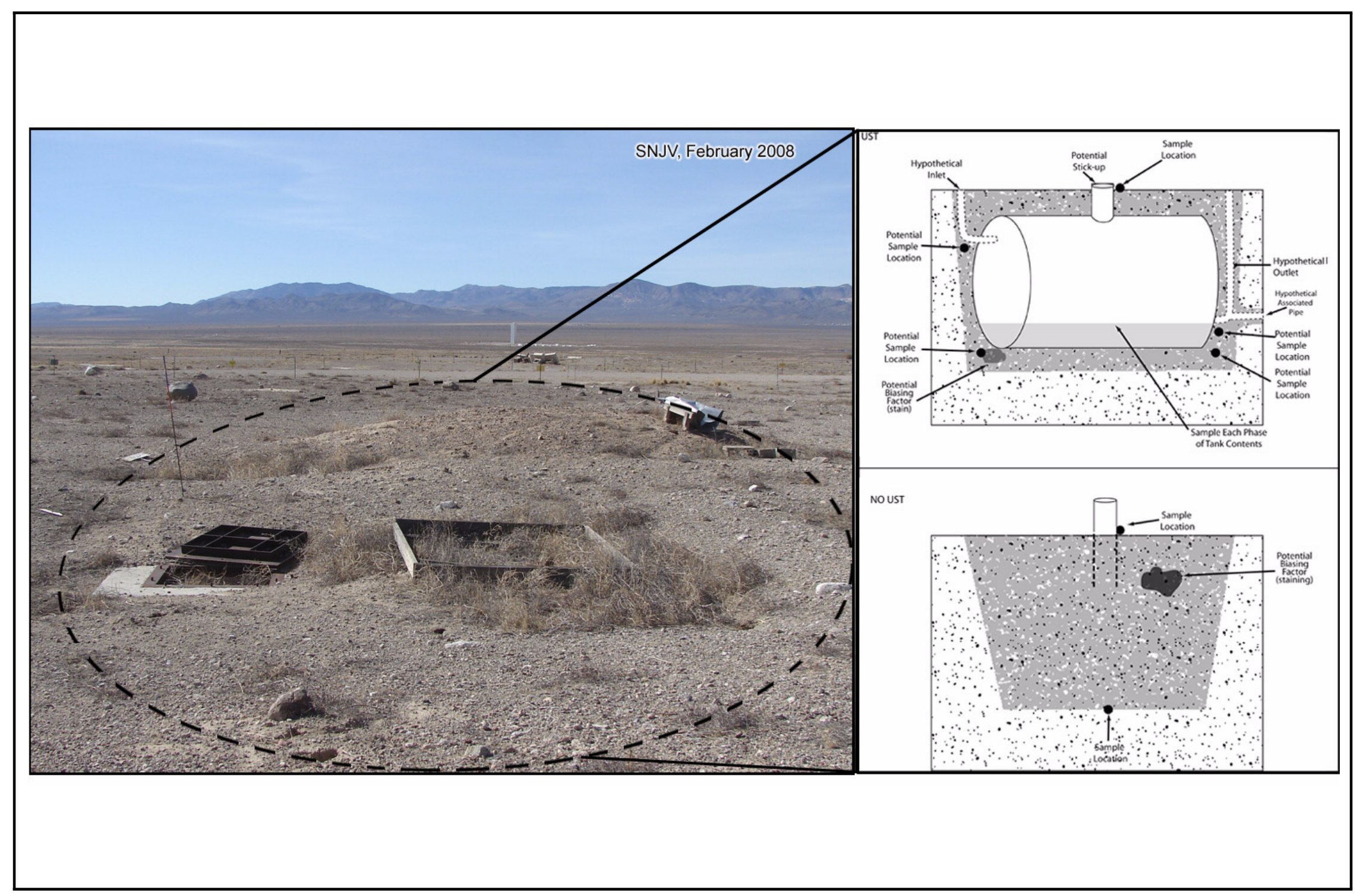

Figure B.8-2

Proposed Sample Strategy at CAS 07-02-01 
If no UST is present, the excavated material will be observed for biasing factors, such as staining to the undisturbed native soil interface. If no biasing factors are observed, then the following additional sampling will be conducted:

- One soil sample will be collected at the undisturbed native soil interface.

- If the undisturbed native soil interface cannot be determined, one soil sample will be collected at approximately $4 \mathrm{ft}$ bgs, and one soil sample will be collected at approximately $6 \mathrm{ft}$ bgs.

Should the excavation reveal a different type of structure (i.e., bunker[s]), the structure(s) will be excavated to the base to investigate a potential for a release. If the structure type is not addressed by the CSM, a revised approach will be developed and approved by the stakeholders before proceeding. Samples will be collected based on biasing factors during the excavation.

Any lead bricks will be removed (and associated soil), and a soil sample will be collected from under the center of the excavation.

Samples will be submitted for analysis in accordance with the analytical program listed in Table 3-1.

\section{B.8.5 Corrective Action Site 10-02-01, Underground Storage Tank}

The judgmental sample locations at CAS 10-02-01 have been selected based on the three 3-in. pipes above ground surface, the concrete pad adjacent to the pipes, and the slightly disturbed soils surrounding the pipes.

Figure B.8-3 shows the proposed sample strategy for CAS 10-02-01. Decision I soil samples will be collected at the surface next to each exposed pipe. One surface soil sample will be collected at the middle edge of each side of the concrete pad. A backhoe will excavate within the area of the UST to determine whether a UST is present. If a UST is present, then the following additional sampling will be conducted:

- The contents, if any, of each phase inside the UST will be sampled.

- One soil sample will be collected under each end of the base of the UST.

- One soil sample will be collected from below the inlet, and one soil sample will be collected from below the outlet piping of the tank if these features are present. 


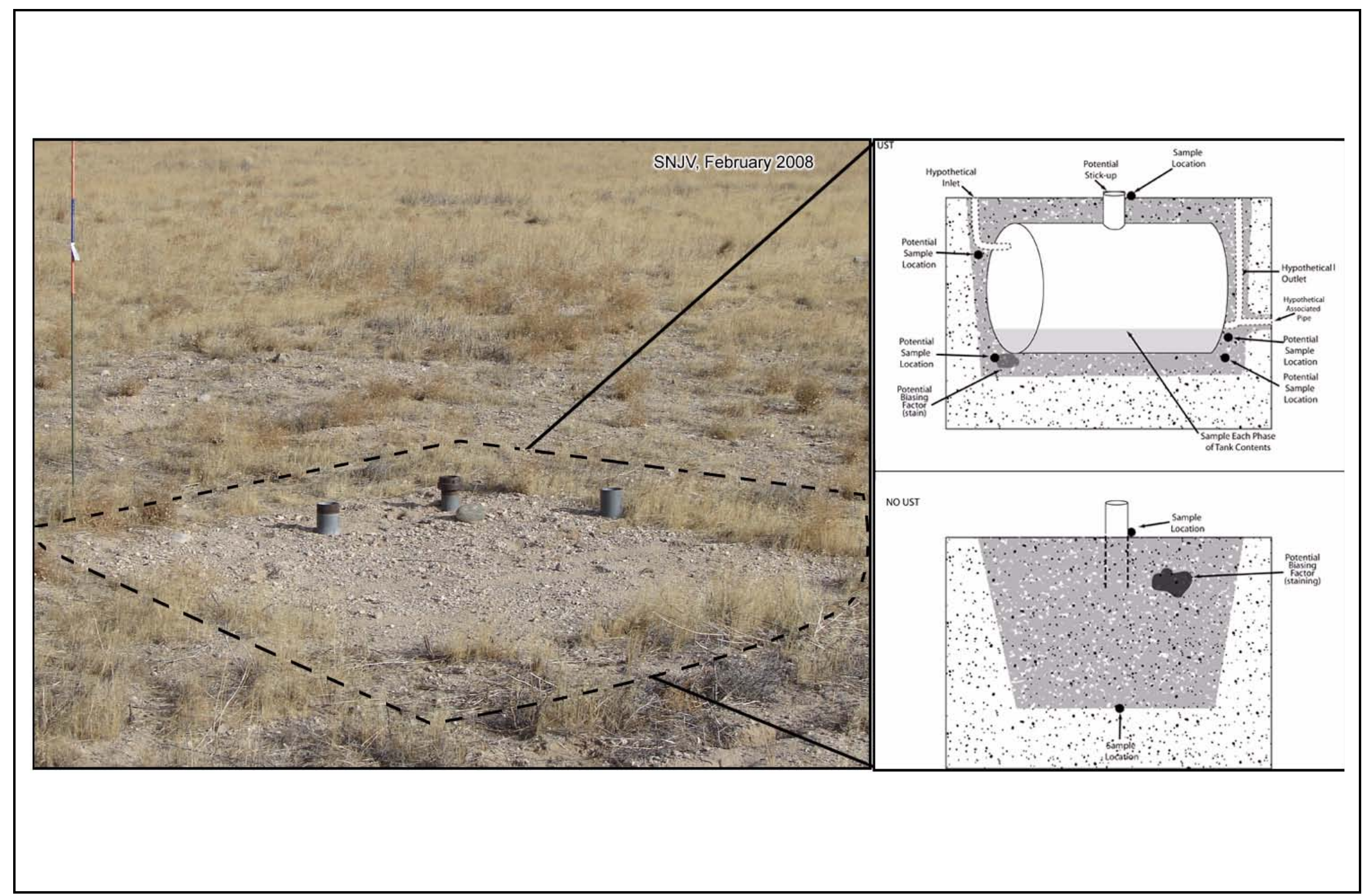

Figure B.8-3

Proposed Sample Strategy at CAS 10-02-01 
- Additional Decision I samples may be collected based on biasing factors during excavation.

- The UST will be closed in accordance with NAC Section 459.9972 (NAC, 2007).

- The UST contents, if any, will be disposed of in accordance with Section 6.0 of this SAFER Plan.

If no UST is present, the excavated material will be observed for biasing factors, such as staining to the undisturbed native soil interface. If no biasing factors are observed, then the following additional sampling will be conducted:

- One soil sample will be collected at the undisturbed native soil interface.

- If the undisturbed native soil interface cannot be determined, one soil sample will be collected at approximately $4 \mathrm{ft}$ bgs, and one soil sample will be collected at approximately $6 \mathrm{ft}$ bgs.

Samples will be submitted for analysis in accordance with the analytical program listed in Table 3-1.

\section{B.8.6 Corrective Action Site 20-02-03, Underground Storage Tank}

The judgmental sample locations at CAS 20-02-03 have been selected based on the planned engineering drawings and the geophysical survey.

Figure B.8-4 shows the proposed sample strategy for CAS 20-02-03. There are two areas that will be excavated: one where the engineered planned drawing depict a UST and one area where the geophysical survey depicts an anomaly. There are no surface features associated with the UST; therefore, no surface samples will be collected. The areas of the UST and anomaly will be excavated. If a UST is present, then the following sampling will be conducted:

- The contents, if any, of each phase inside the UST will be sampled.

- One soil sample will be collected under each end of the base of the UST.

- One soil sample will be collected from below the inlet, and one soil sample will be collected from below the outlet piping of the tank if these features are present.

- Additional Decision I samples may be collected based on biasing factors during excavation. 


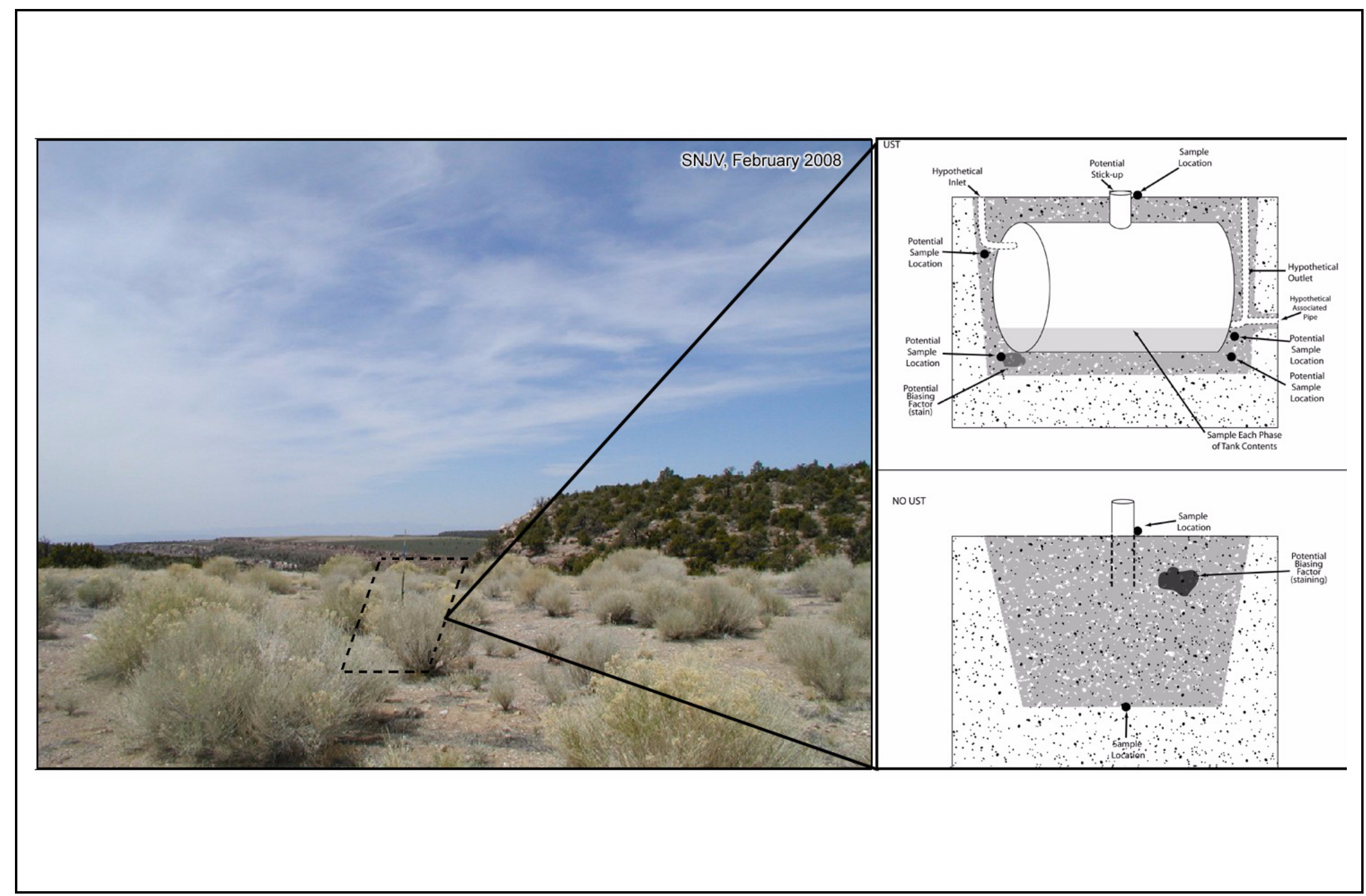

Figure B.8-4

Proposed Sample Strategy at CAS 20-02-03 
- The UST will be closed in accordance with NAC Section 459.9972 (NAC, 2007).

- The UST contents, if any, will be disposed of in accordance with Section 6.0 of this SAFER Plan.

If no UST is present, the excavated material will be observed for biasing factors, such as staining to the undisturbed native soil interface. If no biasing factors are observed, then the following sampling will be conducted :

- One soil sample will be collected at the undisturbed native soil interface.

- If the undisturbed native soil interface cannot be determined, one soil sample will be collected at approximately $4 \mathrm{ft}$ bgs, and one soil sample will be collected at approximately $6 \mathrm{ft}$ bgs.

Samples will be submitted for analysis in accordance with the analytical program listed in Table 3-1.

\section{B.8.7 Corrective Action Site 20-99-05, Tar Residue}

The judgmental sample locations at CAS 20-99-05 have been selected based on the tar on the ground surface that covers an approximate 40 -by-30-ft area. The tar is dark black, hardened, cracked, and brittle material that has a hydrocarbon odor. The patches of tar range from approximately 0.5 to 2.0 in. thick.

Figure B.8-5 shows the proposed sample strategy for CAS 20-02-03:

- The tar will be sampled at two locations to determine whether it is PSM and for waste characterization purposes. The locations will be selected at the two larger areas of accumulated tar, if no other biasing factors are identified.

- Two surface soil samples will be collected beneath two of the larger areas of accumulated tar. Samples will be submitted for analysis in accordance with the analytical program listed in Table 3-1.

\section{B.8.8 Corrective Action Site 22-02-02, Buried UST Piping}

The judgmental sample locations at CAS 22-02-02 have been selected based on site photographs, the association to CAS 22-19-06, Buried Waste Disposal Site, where former USTs and aboveground storage tanks were located, and the geophysical survey. 

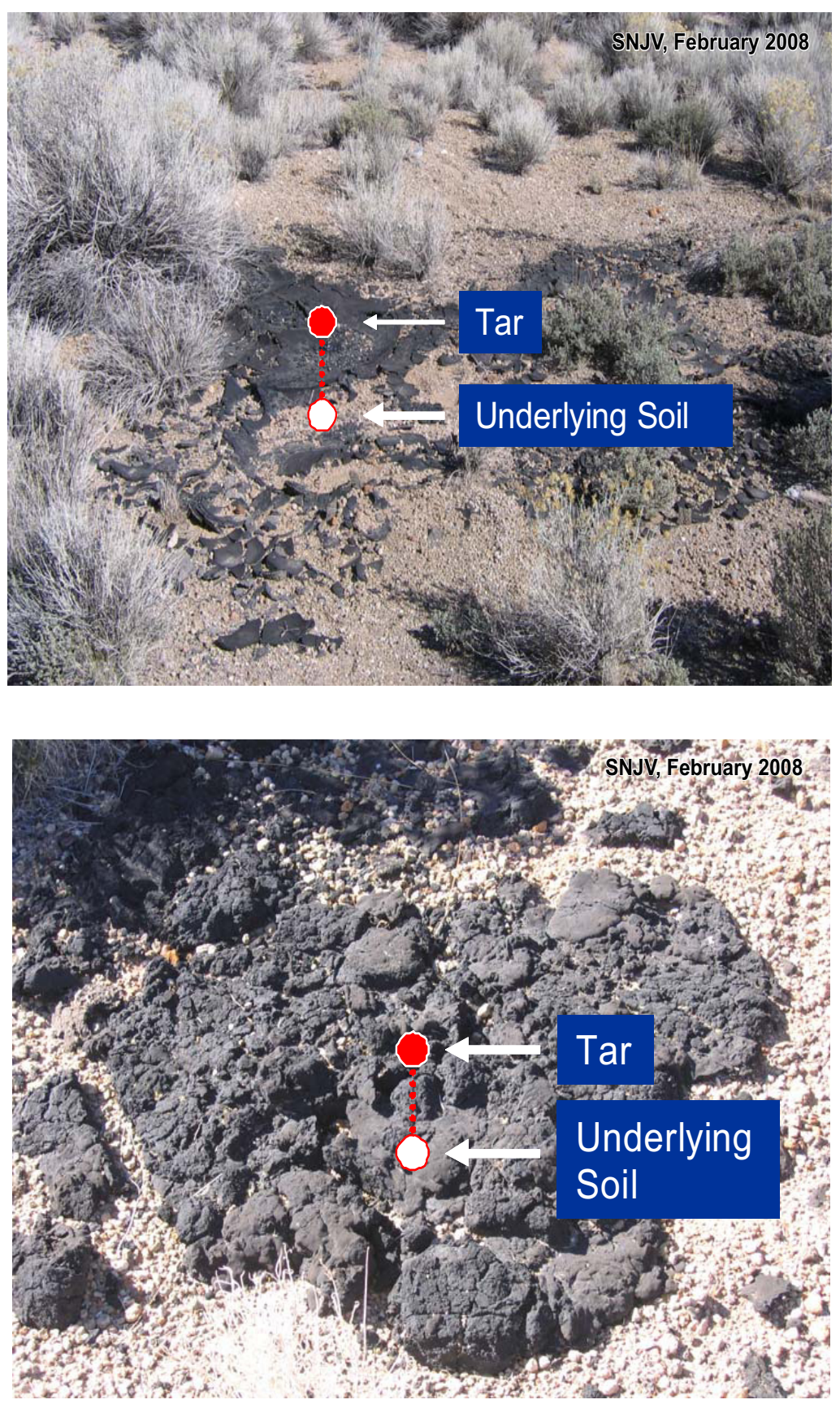

Figure B.8-5

Proposed Sample Strategy at CAS 20-99-05 
Figure B.8-6 shows the proposed sample strategy for CAS 22-02-02.

- One surface soil sample will be collected inside the concrete foundation beneath the pipe opening to include the stained soils.

- One soil sample will be collected below the pipe where it connects to the concrete foundation outer wall.

- One soil sample will be collected below the pipe where it connects to the concrete island.

The buried UST piping will be fully excavated and removed. Soil samples will be collected based on biasing factors observed during excavation.

Samples will be submitted for analysis in accordance with the analytical program listed in Table 3-1.

\section{B.8.9 Corrective Action Site 23-02-07, Underground Storage Tank}

The judgmental sample locations at CAS 23-02-07 have been selected based on the report "Notification to Nevada Division of Environmental Protection (NDEP) of Tank Closures and Upgrades” (Haworth, 1990) and the geophysical survey.

Figure B.8-7 shows the proposed sample strategy for CAS 23-02-07. There are no surface features associated with the UST; therefore, no surface samples will be collected. A backhoe will excavate within the area of the UST to determine whether a UST is present. If a UST is present, and the UST has not been filled with inert material (i.e., grout), then:

- The contents, if any, of each phase inside the UST will be sampled.

- $\quad$ One soil sample will be collected under each end of the base of the UST.

- One soil sample will be collected from below the inlet, and one soil sample will be collected from below the outlet piping of the tank if these features are present.

- Additional Decision I samples may be collected based on biasing factors during excavation.

- $\quad$ The UST will be closed in accordance with NAC Section 459.9972 (NAC, 2007).

- The UST and contents, if any, will be disposed of in accordance with Section 6.0 of this SAFER Plan. 


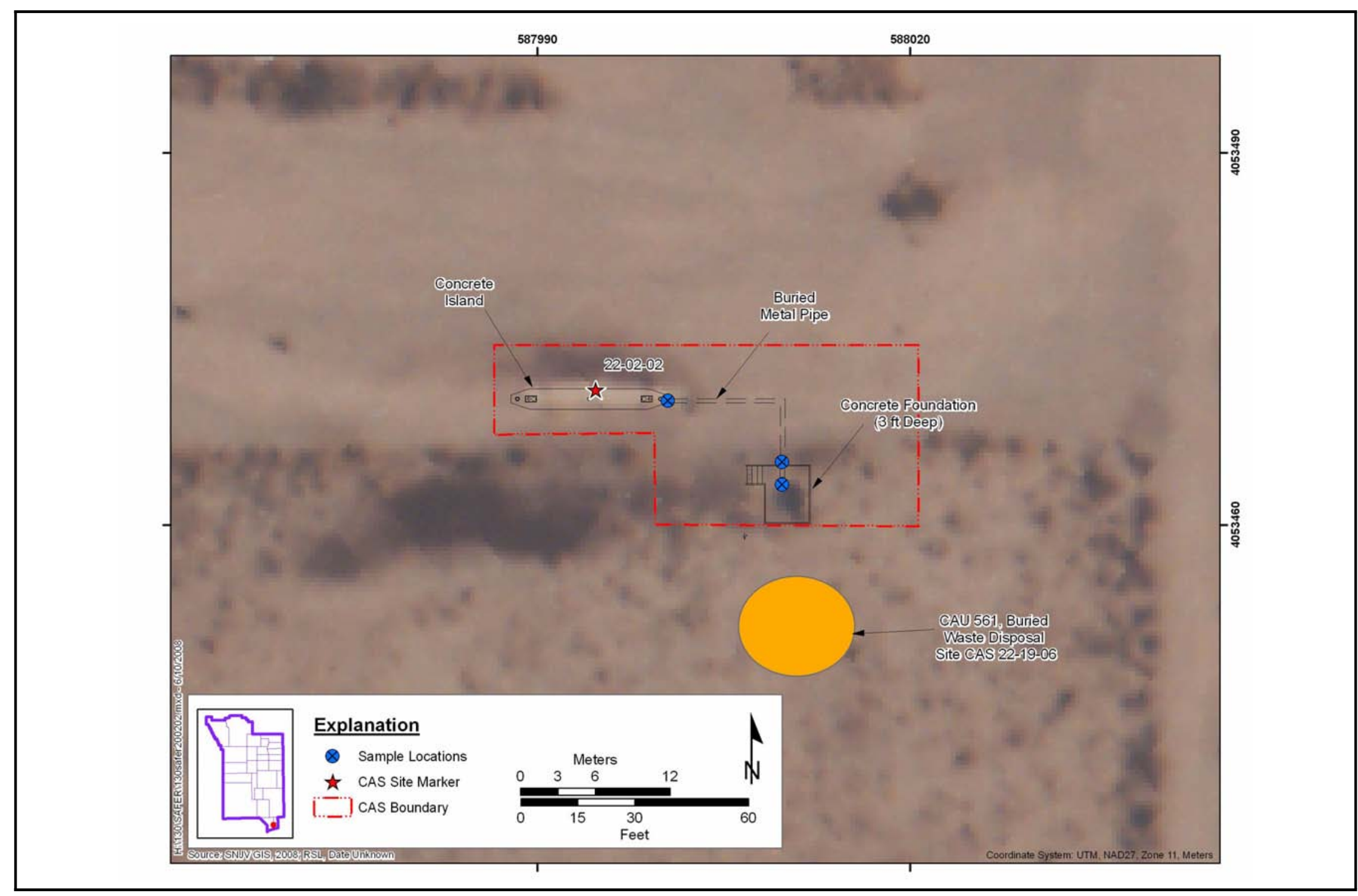

Figure B.8-6

Proposed Sample Strategy at CAS 22-02-02 


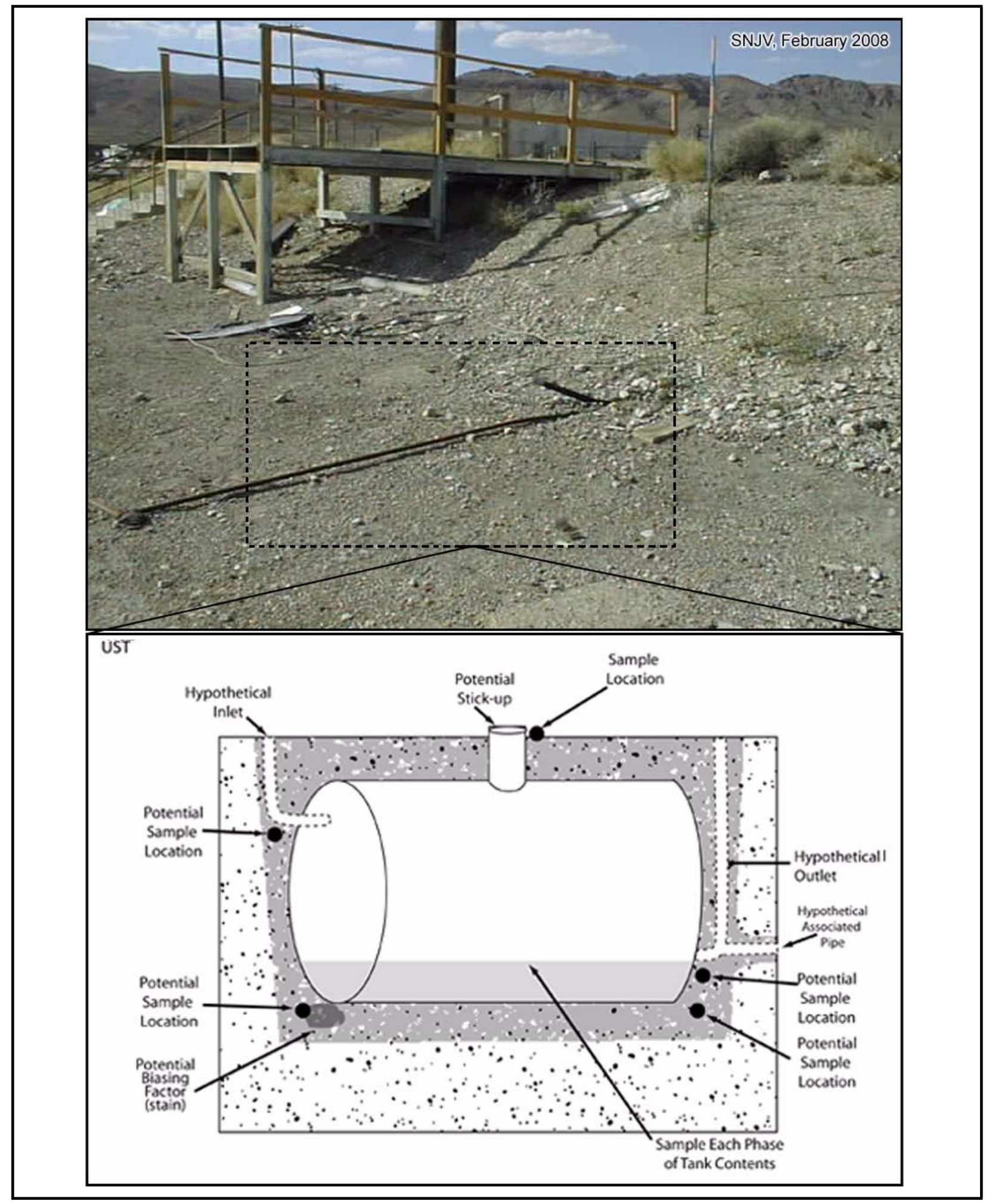

Figure B.8-7

Proposed Sample Strategy at CAS 23-02-07 
If the UST is in place and filled with inert material (i.e., grout), then:

- One soil sample will be collected under each end of the base of the UST.

- Additional Decision I samples may be collected based on biasing factors.

If no UST is present, the excavated material will be observed for biasing factors, such as staining to the undisturbed native soil interface. If no biasing factors are observed, then:

- One soil sample will be collected at the undisturbed native soil interface.

- If the undisturbed native soil interface cannot be determined, one soil sample will be collected at approximately $4 \mathrm{ft}$ bgs, and one soil sample will be collected at approximately $6 \mathrm{ft}$ bgs.

Samples will be submitted for analysis in accordance with the analytical program listed in Table 3-1. 


\section{B.9.0 References}

ARL/SORD, see Air Resources Laboratory/Special Operations and Research Division.

ASTM, see American Society for Testing and Materials.

Air Resources Laboratory/Special Operations and Research Division. 2006. Air Resources Laboratory/Special Operations and Research Division website. As accessed at http://www.sord.nv.doe.gov/home_climate.htm on 3 March 2008.

American Society for Testing and Materials. 1995. Standard Guide for Risk-Based Corrective Action Applied at Petroleum Release Sites, ASTM E 1739-95 (Reapproved 2002). Philadelphia, PA.

DOE, see U.S. Department of Energy.

DOE/NV, see U.S. Department of Energy, Nevada Operations Office.

EPA, see U.S. Environmental Protection Agency.

Haworth, O. Bechtel Nevada. 1990. Letter entitled "Notification to Nevada Division of Environmental Protection (NDEP) of Tank Closures and Upgrades,” 17 December. Las Vegas, NV.

Moore, J., Science Applications International Corporation. 1999. Memorandum to M Todd (SAIC) entitled, “Background Concentrations for NTS and TTR Soil Samples,” 3 February. Las Vegas, NV: IT Corporation.

Murphy, T., Bureau of Federal Facilities. 2004. Letter to R. Bangerter (NNSA/NSO) entitled, "Review of Industrial Sites Project Document Guidance for Calculating Industrial Sites Project Remediation Goals for Radionuclides in Soil Using the Residual Radiation (RESRAD) Computer Code.” 19 November. Las Vegas, NV.

NAC, see Nevada Administrative Code.

NBMG, see Nevada Bureau of Mines and Geology.

NCRP, see National Council on Radiation Protection and Measurements.

NNSA/NSO, see U.S. Department of Energy, National Nuclear Security Administration Nevada Site Office.

NNSA/NV, see U.S. Department of Energy, National Nuclear Security Administration Nevada Operations Office. 
National Council on Radiation Protection and Measurements. 1999. Recommended Screening Limits for Contaminated Surface Soil and Review of Factors Relevant to Site-Specific Studies, NCRP Report No. 129. Bethesda, MD.

Nevada Administrative Code. 2006a. NAC 445A.227, “Contamination of Soil: Order by Director for Corrective Action; Factors To Be Considered in Determining Whether Corrective Action Required.” Carson City, NV. As accessed at http://www.leg.state.nv.us/nac on 3 March 2008.

Nevada Administrative Code. 2006b. NAC 445A.22705, "Contamination of Soil: Evaluation of Site by Owner or Operator; Review of Evaluation by Division.” Carson City, NV. As accessed at http://www.leg.state.nv.us/nac on 3 March 2008.

Nevada Administrative Code. 2006c. NAC 445A.2272, “Contamination of Soil: Establishment of Action Levels.” Carson City, NV. As accessed at http://www.leg.state.nv.us/nac on 3 March 2008.

Nevada Administrative Code. 2007. NAC 459.9972, “Assessment Required before Closure of Tank; Removal of Tank from Ground.” Carson City, NV. As accessed at http://www.leg.state.nv.us/nac on 3 March 2008.

Nevada Bureau of Mines and Geology. 1998. Mineral and Energy Resource Assessment of the Nellis Air Force Range, Open-File Report 98-1. Reno, NV.

RSL, see Remote Sensing Laboratory.

Remote Sensing Laboratory. Date Unknown. Aerial photograph “8450.” Las Vegas, NV.

SNJV GIS, see Stoller-Navarro Joint Venture Geographic Information Systems.

Stoller-Navarro Joint Venture Geographic Information Systems. 2008. ESRI ArcGIS Software.

U.S. Department of Energy. 1993. Radiation Protection of the Public and the Environment, DOE Order 5400.5, Change 2. Washington, DC: U.S. Government Printing Office.

U.S. Department of Energy, National Nuclear Security Administration Nevada Operations Office. 2002. Industrial Sites Quality Assurance Project Plan, Nevada Test Site, Nevada, Rev. 3, DOE/NV--372. Las Vegas, NV.

U.S. Department of Energy, National Nuclear Security Administration Nevada Site Office. 2006. Industrial Sites Project Establishment of Final Action Levels, DOE/NV--1107, Rev. 0. Las Vegas, NV.

U.S. Department of Energy, Nevada Operations Office. 1996. Final Environmental Impact Statement for the Nevada Test Site and Off-Site Locations in the State of Nevada, DOE/EIS0243. Las Vegas, NV. 
U.S. Department of Energy, Nevada Operations Office. 1998. Nevada Test Site Resource Management Plan, DOE/NV-518. Las Vegas, NV.

U.S. Environmental Protection Agency. 2002. Guidance for Quality Assurance Project Plans, EPA QA/G5. Washington, DC.

U.S. Environmental Protection Agency. 2004. Region 9 Preliminary Remediation Goals (PRGs). As accessed at http://www.epa.gov/region09/waste/sfund/prg/index.htm on 3 March 2008. Prepared by S.J. Smucker. San Francisco, CA.

U.S. Environmental Protection Agency. 2006. EPA Guidance on Systematic Planning Using the Data Quality Objectives Process, EPA QA/G-4. Washington, DC.

Winograd, I.J., and W. Thordarson. 1975. Hydrology and Hydrochemical Framework, South-Central Great Basin, Nevada-California, with Special Reference to the Nevada Test Site, USGS Professional Paper 712-C. Denver, CO. 


\section{Appendix C}

\section{Nevada Division of Environmental Protection Comments}

(2 Pages) 


\section{NEVADA ENVIRONMENTAL RESTORATION PROJECT DOCUMENT REVIEW SHEET}

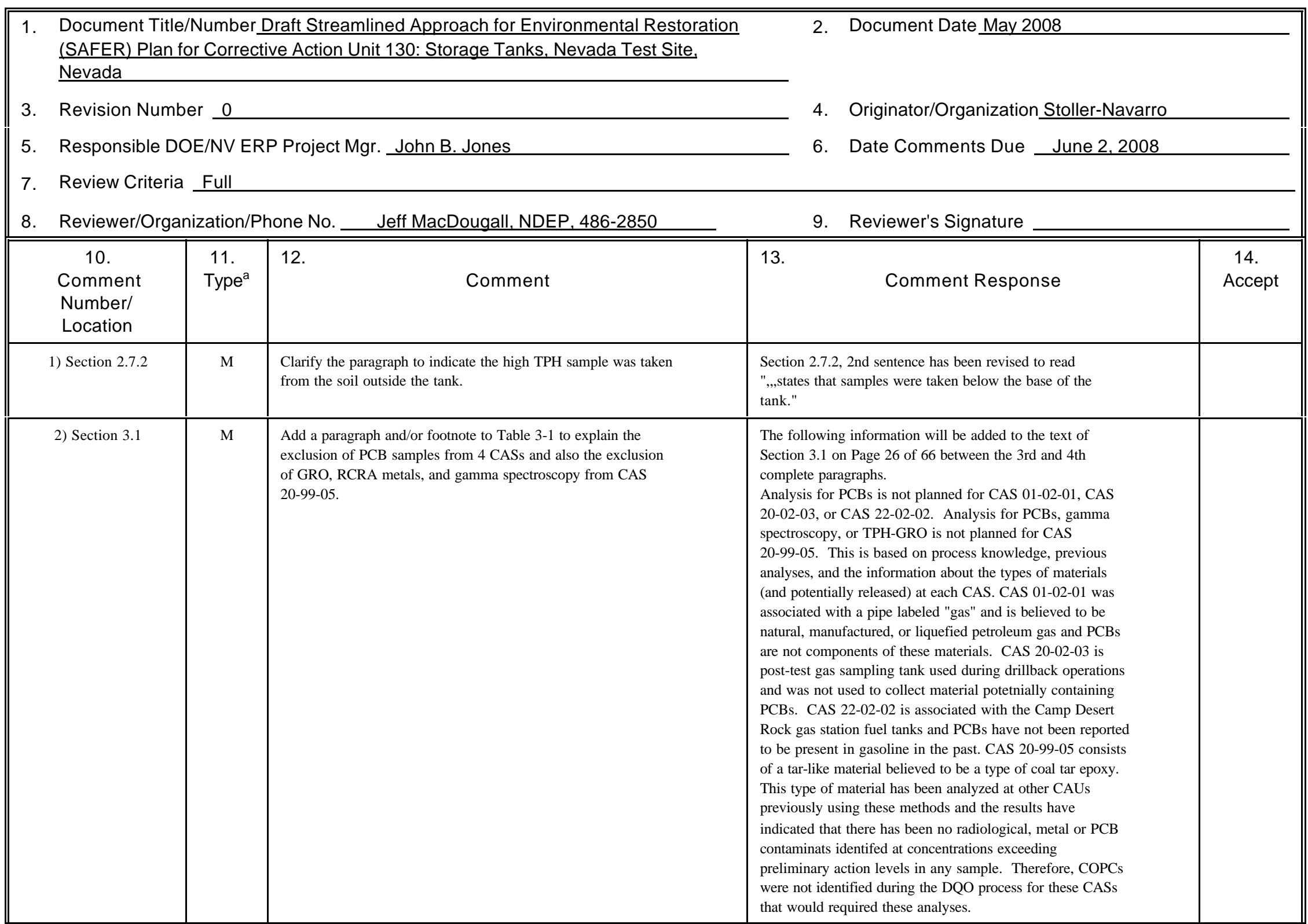

a Comment Types: $\mathrm{M}=$ Mandatory, $\mathrm{S}=$ Suggested.

Return Document Review Sheets to DOE/NV Environmental Restoration Division, Attn: QAC, M/S 505.

\section{UNCONTROLLED when Printed}




\section{NEVADA ENVIRONMENTAL RESTORATION PROJECT DOCUMENT REVIEW SHEET}

Document Title/Number Draft Streamlined Approach for Environmental Restoration (SAFER)

Revision Number $\underline{0}$ Plan for Corrective Action Unit 130: Storage Tanks, Nevada Test Site, Nevada

Reviewer/Organization Jeff MacDougall, NDEP, 486-2850

\begin{tabular}{|c|c|c|c|c|}
\hline $\begin{array}{c}10 . \\
\text { Comment } \\
\text { Number/ } \\
\text { Location }\end{array}$ & $\begin{array}{l}11 . \\
\text { Type }^{\mathrm{a}}\end{array}$ & Comment & Comment Response & $\begin{array}{l}14 . \\
\text { Accept }\end{array}$ \\
\hline $\begin{array}{l}\text { 3) Section B.7.2, } \\
\text { Page } 31 \text {, } \\
2^{\text {nd }} \text { Paragraph }\end{array}$ & M & $\begin{array}{l}\text { Double check the referenced Section } 6.2 .2 \text { used in this } \\
\text { paragraph twice. It should reference Section } 7.2\end{array}$ & $\begin{array}{l}\text { Section B.7.2, Page } 31 \text {, 2nd Paragraph: The reference to } \\
\text { Section } 6.2 .2 \text { has been revised to Section } 7.2 \text { in two } \\
\text { locations within the paragraph. }\end{array}$ & \\
\hline
\end{tabular}




\title{
Library Distribution List
}

\author{
$\underline{\text { Copies }}$ \\ U.S. Department of Energy \\ 1 (Uncontrolled, electronic copy) \\ National Nuclear Security Administration \\ Nevada Site Office \\ Technical Library \\ P.O. Box 98518, M/S 505 \\ Las Vegas, NV 89193-8518 \\ U.S. Department of Energy \\ Office of Scientific and Technical Information \\ 1 (Uncontrolled, electronic copy) \\ P.O. Box 62 \\ Oak Ridge, TN 37831-0062 \\ Southern Nevada Public Reading Facility \\ 2 (Uncontrolled, electronic copies) \\ c/o Nuclear Testing Archive \\ P.O. Box 98521, M/S 400 \\ Las Vegas, NV 89193-8521 \\ Manager, Northern Nevada FFACO \\ 1 (Uncontrolled, electronic copy) \\ Public Reading Facility \\ c/o Nevada State Library \& Archives \\ 100 N Stewart Street \\ Carson City, NV 89701-4285
}

